

\section{Editorial Board}

\section{Editor in Chief}

Mark Zilberman, MSc, Shiny World Corporation, Toronto, Canada

\section{Scientific Editorial Board}

Viktor Andrushhenko, PhD, Professor, Academician of the Academy of Pedagogical Sciences of Ukraine, President of the Association of Rectors of pedagogical universities in Europe

John Hodge, MSc, retired, USA

Petr Makuhin, PhD, Associate Professor, Philosophy and Social Communications faculty of Omsk State Technical University, Russia

Miroslav Pardy, PhD, Associate Professor, Department of Physical Electronics, Masaryk University, Brno, Czech Republic

Lyudmila Pet'ko, Executive Editor, PhD, Associate Professor, National Pedagogical Dragomanov University, Kiev, Ukraine

\section{Intellectua|Archive, Volume 7, Number 5}

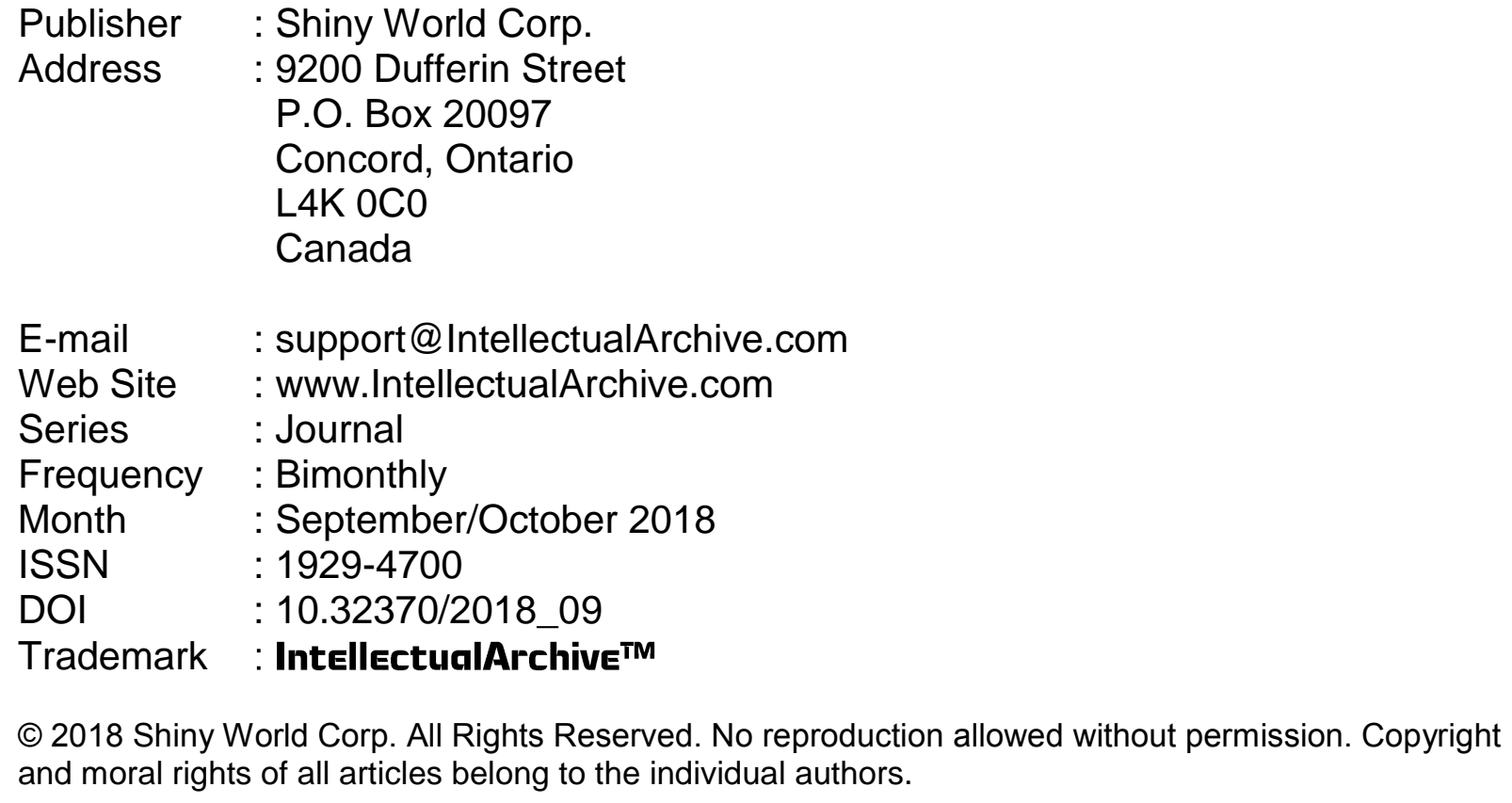

(C) 2018 Shiny World Corp. All Rights Reserved. No reproduction allowed without permission. Copyright and moral rights of all articles belong to the individual authors. 


\section{Intellectual Archive}

Volume 7

J. Hodge

A. Bolonkin

Y. Klimov, O. Klimov

T. Abdullayeva

L. Filonenko

S. Petrova

O. Komarovska, Huang Hanjie

R. Mustafaev

J. Hodge
Number 5

September/October 2018

\section{Table of Contents}

\section{Physics}

Scalar Theory of Everything Replacement of Special Relativity

\section{Technology}

Flight of Outer Solar System (Part 4)

\section{Information Science}

Benford's Law in Information Science

\section{Literature}

Children's Literature Tracks in Disney Films and Azerbaijani Children's Auditorium

\section{Education}

Pedagogical Conditions of the Formation of Value Attitude to Another Person in Teenagers of Comprehensive Boarding Schools

The Specifics of Teenager's Socialisation in Orphanage "Perlynka"

Readiness for Stage Partnership in Vocal-Ensemble Performance as a Vector in

Professional Training Music Teachers

\section{Mathematics}

Establishing Patterns of Formation and Distribution of Primes to Infinity (Riemann Hypothesis)

\section{Book Presentation}

STOE replaces relativity and quantum mechanics

\section{Toronto, September/October 2018}




\title{
Scalar Theory of Everything replacement of Special Relativity
}

\author{
J.C. Hodge ${ }^{1 *}$ \\ ${ }^{1}$ Retired, 477 Mincey Rd., Franklin, NC, 28734
}

\begin{abstract}
The Special Theory of Relativity applies where gravitation is insignificant. There are many observations that remain poorly explained by the standard models of either the big of cosmology or the small of Quantum mechanics. Each of the STOE axioms has been used in the development of models of observations in the big and the small. The strength of the Scalar Theory Of Everything (STOE) is its ability to describe an extremely wide range of observations and to predict observations. The axioms that replace Special Relativity are: (1) Time progression $(\mathrm{d} t)$ is a constant in the universe rather than the speed of light. (2) The diameter of the hods is the same throughout the universe. (3) The distance between hods is related to plenum density $\rho$. Higher $\rho$ reduces the distance between hods. (4) The speed of photons and hods is the greatest of any matter in a given environment. And (5) The speed of the plenum wave is much faster than the speed of the hods. The STOE passes the tests of Special Relativity and does much more. The STOE is a major paradigm shift.
\end{abstract}

keywords: STOE, special relativity

\section{INTRODUCTION}

The theory of Special Relativity (SR) was developed from consideration of the aberration of light, Lorentz's elaborations of Maxwell's equations (independence of the speed of light $c$ of the source and observer), the moving magnet and conductor thought experiment, the null results of aether drift experiments, and the Fizeau experiment (suggesting the $c$ is modified to $c / n$ where $n$ is the index of refraction). Additional experiments considered to be tests of SR are the Doppler effect, the Kennedy-Thorndike like experiments (testing constancy of $c$ ) and Ives-Stilwell like experiments (testing time dilation and length contraction).

The Scalar Theory Of Everything (STOE) was developed to model cosmological problems (Hodge 2015d). Hodge (2004) posited the universe was composed of two components and their interaction.

*E-mail: jchodge@frontier.com 


\section{NULL EXPERIMENTS}

The STOE application to SR started with Newton's speculations about corpuscular nature of light (Hodge 2012). A particle model of diffraction and interference must first describe "coherence" of light. Passing the light through a slit in a mask tests coherence. If the light is coherent, a diffraction pattern appears on a screen. If the light is not coherent, a diffraction pattern will not appear on a screen.

Hodge (2012) expanded on the characteristics of the plenum, hods, and their interactions to derive the STOE particle ${ }^{1}$ photon diffraction model. This photon model and a toy simulation program were developed to yield a diffraction pattern after random particle photons moved a large distance that simulated the development of coherence of light. The computer program involved several iterations, which raises the specter of chaos. However, chaos is avoided by having several feedback conditions that are also in nature. Passing the photons through a slit and matching the screen pattern to a Fraunhofer pattern demonstrated coherence. Other observations suggest the photon distribution in a laser beam and explain the Afshar Experiment.

The photon model was extended and modified to describe the single photon at a time in the experiment (Hodge 2015c, and references therein). This model suggested the experiments (Hodge Experiments) involving the varying illumination of coherent light across a slit(Hodge 2017a,b). The prediction was found to be consistent with the observations of Hodge Experiments. The Hodge Experiments rejected all wave models of light. One of the characteristics of this model is that the $c$ varies linearly with the $\rho$ and is the highest speed that any matter (hods) may achieve. Because the $\rho$ caused by the Sun and the universe may vary locally to the photon without being in a refractive substance, this model differs from the Fizeau model.

The STOE addressed Maxwell's Equations by experiments that suggested the "moving magnet and conductor thought experiment" had a basis in a different view of the Biot-Savart Law and the magnetic field (Hodge 2018a,b,c).

The sections of this paper discuss the aspects of Special Reletivity:

2 Null Experiments

3 Length contraction

4 Doppler shift

5 Clocks

6 Time dilation

7 Discussion and Conclusion.

\section{Null experiments}

The null experiments such as the Michelson-Morely Experiment are explained because the $\rho$ and $\vec{\nabla} \rho$ (gravity) are constant across the experiment. The $\rho$ caused by the Sun and Moon cause tides. But the changes around the experiment are too slow and may have caused the P.M observations to be slightly higher

\footnotetext{
${ }^{1} \mathrm{~A}$ distinction is made between a wave packet type model that is called a "photon" and a particle type model.
} 


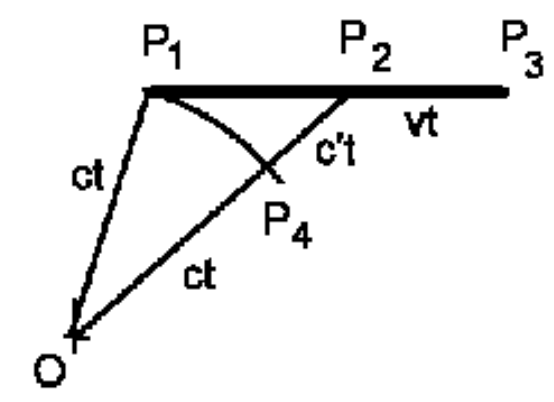

Figure 1: The length of a rod and its measured length.

than the noon observations (Sun perpendicular to the plane of the experiment) (Michelson \& Morley 1987). Therefore, there is no wind causing the required change in the diffraction pattern, but a tidal force of $\vec{\nabla} \rho$ is present.

\section{Length contraction}

Length contraction is a measurement phenomenon. That is, the length of rods does not change from one inertial frame to another due to the relative velocity. Figure 1 shows the actual length of a rod $l=P_{3}-P_{1}$ in the comoving coordinate system where the P's are points of interest. The length $l^{\prime}=P_{2}-P_{1}$ as measured in another coordinate system $(\mathrm{O})$ moving at a constant velocity $v$. The distance moved during the time $t$ a photon takes to move from $P_{1}$ to $O$ is $v t$ as shown on the diagram. $P_{2}$ was the position of the end $\left(P_{3}\right)$ at $t=0$. During $t$, light travels toward the observer and moves a distance of $c^{\prime} t$. That is, the direction of light appears to originate from each end of the rod. Therefore, the $l^{\prime}<l$ by the Lorentz factor.

Lorentz suggested the structure of particles contracted with relative velocity. The STOE suggests the distance between hods in particle structures lessens in greater $\rho$ environments. This lessens the particles' size but not the mass. Thus, particles contract toward the center of spiral galaxies and become black holes. The black holes compress to release high-energy photons which radiate outward as observed in periodic X-ray bursts without accompanying radiation of other frequencies (Hodge 2006b). A subset of length contraction is aberration because of the direction of photon movement. 


\section{Doppler shift}

The STOE models the primary redshift of galaxies as a variation of the photon energy as it travels through space (Hodge 2006a). The STOE model accounted for redshift galaxies, some blueshift galaxies, and reduced to the Hubble Law for distances outside our galaxy cluster. The same equation was applied to the Pioneer Anomaly (Hodge 2006c). The Doppler shift of light from galaxies is from the stars in the galaxy. Some stars in a galaxy are approach us relative to the galaxy as a whole. Some are receding.

The model of a photon (Hodge 2012) included the simulation of how a random distribution of photons become coherent with distance traveled. The forces on the photons force them to become organized in accordance with the number of hods (frequency) in a photon as depicted in Fig. 2. The speed of photons is the fastest that matter can travel in any environment. If the source is moving away from the direction of previously emitted photons, the rate spacing of the photons becomes longer Fig. 3. The photons are no longer coherent. The STOE suggests the forces on the photon tend toward becoming coherent. But all are traveling at the same speed. The addition of hods to matter particles has been assumed for galaxy redshift, the Doppler effect, and for the generation of the magnetic field of electromagnetic waves of photons. They become coherent by attracting free hods or by ejecting hods during their travel. The coherent grouping is reestablished (see Fig. 4 and Fig. 5).

The redshift equations were successfully applied to the Pioneer Anomaly (Hodge 2006c). The Pound-Rebka Experiment also has photons experiencing a redshift and a blueshift while traveling in a changing $\rho$ potential. The change in photon frequency was measured with the Doppler Effect. Thus, the PoundRebka Experiment uses models of both the Doppler Effect and time dilation. The STOE redshift equations alone are insufficient. That is, in the STOE model there are more parameters to be determined than there are observation data points. Therefore, their results may be erroneous.

A distinction is made between the velocity of an object such as hods that depends on the environment ( $\rho$ and $n$ ) along its path and the velocity of an object such as bullets and balls that depend on the velocity of the source.

\section{Clocks}

Consider a pendulum clock. The pendulum clock is well modeled. We can predict the tick rate if the clock is placed in a box and dropped. The time between ticks slows if not stops. Similarly, the tick rate slows or stops if placed in an accelerating plane, at a higher altitude, etc.

We have no model of the decay rates beyond the statistical description. But, the statistical description omits the mechanism of decay. Without the knowledge of the mechanism of decay, ascribing the rate of time progression to time dilation is questionable. For example, the muon decay rate while falling may be analogous to a free falling pendulum clock in a box. 


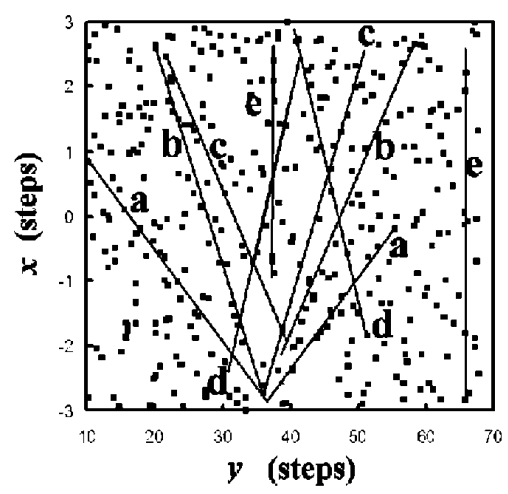

Figure 2: Coherent distribution of photons from Hodge (2012).

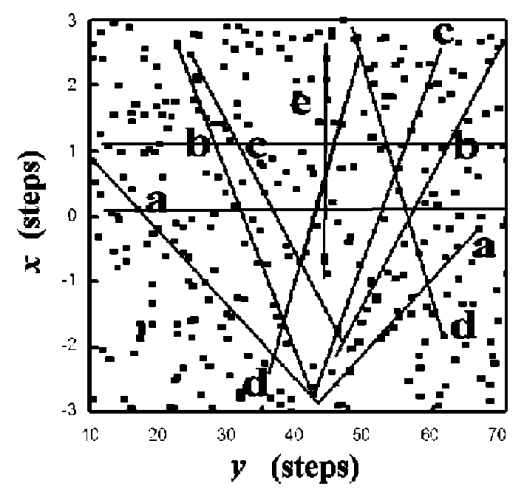

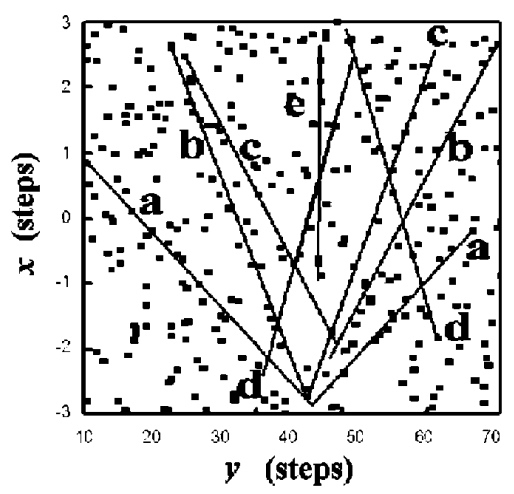

Figure 3: Distribution of coherent photons if source moving away.

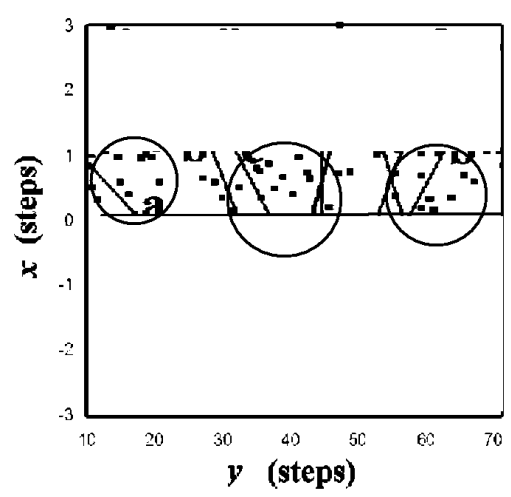

Figure 4: Distribution of coherent Figure 5: Distribution of coherent photons if source moving away fo- photons if source moving away focused view. cused view with the concentrated areas circled. 
The change in decay rate may be an indication of the cause of decay.

\section{Time dilation}

Another phenomenon attributed to time dilation is two different photons traveling through the plenum with different $\rho$. For example, the Shapiro delay of the photons traveling closer to the Sun is traveling through a lower $\rho$ than the photon traveling farther from the Sun. The STOE suggest the time difference is because the slower speed of the photons traveling closer to the Sun. Therefore, the delay is the slower speed not time dilation. Another phenomenon is the bending of light around massive objects. The inner photons travel slower. This is consistent with the Hodge diffraction experiment (Hodge 2015c).

\section{Discussion and Conclusion}

The list of problematical observations that the STOE explains continues to grow with an improved understanding of the universe (Hodge 2015d, 2016).

The scalar $\rho$ depends on all the masses, sources and sinks in the universe. The $\vec{\nabla} \rho$ gives the "gravity" and Mach's Principle. The STOE Relativity considers the accelerated frame indistinguishable from the inertial frame. This has already been used to calculate the galaxy redshift and the Pioneer Anomaly. This gives the Poisson Equation. The STOE extends into General Relativity scales by considering the changes in position of the masses, sources, and sinks which will yield the d'Alembert's Equation without the complexity of tensor General Relativity which involves the conversion to geometry and the inverse conversion to gain physical observations.

The STOE calculates all physical quantities as invariant under velocity except as specifically calculated or as caused by changes in $\rho$. Therefore, the laws of nature are scale invariant. Therefore, the relation of gravity and scale invariance becomes clear.

The STOE rejects the notion of space-time because of the arrow-of-time. The STOE arrives at the Equivalence Principle by a particle structure argument (Hodge 2015e). Therefore, geometric gravity and space-time are unnecessary.

Each of the STOE axioms has been used in the development of models of observations in the big and the small. The strength of the Scalar Theory Of Everything (STOE) is its ability to describe an extremely wide range of observations and to predict observations. The axioms that replace Special Relativity are: (1) Time progression $(\mathrm{d} t)$ is a constant in the universe rather than the speed of light. (2) The diameter of the hods is the same throughout the universe. (3) The distance between hods in a particle is related to plenum density $\rho$. Higher $\rho$ reduces the distance between hods. (4) The speed of photons and hods is the greatest of any matter in a given environment. And (5) The speed of the plenum wave is much faster than the speed of the hods. The STOE passes the tests of Special Relativity and does much more. The STOE is a major paradigm shift. 


\section{REFERENCES}

\section{References}

Hodge, J.C., 2004, Changing universe model with applications, http://www.arxiv.org/PS_cache/astro-ph/pdf/0409/0409765v1.pdf

Hodge, J.C., 2006a, Scalar potential model of redshift and discrete redshift, New Astronomy, Volume 11, Issue 5, March 2006, Pages 344358. http://www.sciencedirect.com/science/article/pii/S1384107605001387. http://www.arxiv.org/PS_cache/astro-ph/pdf/0602/0602344v1.pdf

Hodge, J.C., 2006b, Scalar potential model of the CMB radiation temperature, https://www.arxiv.org/abs/astro-ph/0603140

Hodge, J.C., 2006c, Scalar potential model of the Pioneer Anomaly, http://www.arxiv.org/PS_cache/astro-ph/pdf/0612/0612567v2.pdf

Hodge, J.C., 2012, Photon diffraction and interference, IntellectualArchive, Vol.1, No. 3, P. 15, http://intellectualarchive.com/?link=item\&id=597

Hodge, J.C., 2015a, Single Photon diffraction and interference, http://intellectualarchive.com/?link=item\&id=1557

Hodge, J.C., 2015b, Light diffraction experiments that confirm the STOE model and reject all other models, http://intellectualarchive.com/?link=item\&id=1578

Hodge, J.C., 2015c, Diffraction experiment and its STOE photon toy simulation program rejects wave models of light, http://intellectualarchive.com/?link=item\&id=1603 see video "stoe photon diffraction". (https://www.youtube.com/channel/UCc0mfCssV32dDhDgwqLJjpw)

Hodge, J.C., 2015d, Universe according to the STOE, http://intellectualarchive.com/?link=item\&id=1648

Hodge, J.C., 2015e, Structure and spin of the neutrino, electron, and positron, IntellectualArchive, Vol.5, No. 2, P.1-8 , http://intellectualarchive.com/?link=item\&id $=1648$

Hodge, J.C., 2016, STOE assumptions that model particle diffraction and that replaces $Q M$, http://intellectualarchive.com/?link=item\&id=1719

Hodge, J.C., 2017a, Hodge experiment (continued) of interference with a slit in a transparent mask rejects wave models of light, IntellectualArchive, Vol.6, No. 6, p.1-6 http://intellectualarchive.com/?link=item\&id=1862 video: https://www.youtube.com/watch?v=A07bogzzMEI

Hodge, J.C., 2017b, Hodge experiment (continued) with opaque strips and about the Afshar Experiment, IntellectualArchive, Vol.6, No. 5, p.7-18 http://intellectualarchive.com/?link=item\&id =1872 


\section{REFERENCES}

Hodge, J.C., 2018a, Magnetostatics relation to gravity with experiment that rejects Biot-Savart Law, IntellectualArchive, Vol.7, No. 3, p.1-8 http://intellectualarchive.com/?link=item\&id $=1845$

Hodge, J.C., 2018b, Another experiment rejects Ampere's Law and supports the STOE model, IntellectualArchive, Vol.7, No. 4, p.1-5 http://intellectualarchive.com/?link=item\&id=1956

Hodge, J.C., 2018c, Two different types of magnetic field, IntellectualArchive, Vol.7, No. 4, p.1-8 http://intellectualarchive.com/?link=item\&id=1964

Michelson, A.A. \& Morley, E.W., 1987, On the Relative Motion of the Earth and the Luminiforus Ether, American Journal of Science, 34 (203) p. 333-345. 


\title{
Flight of Outer Solar System
}

\section{Part $4^{*}$. Converting of any Matter to Nuclear Energy and Photon Rocket for Flight outer Solar System ${ }^{* *}$}

\author{
Alexander Bolonkin \\ $C \& R$, abolonkin@gmail.com
}

\begin{abstract}
Author offers a new nuclear generator which allows to convert any matter to nuclear energy in accordance with the Einstein equation $E=m c^{2}$. The method is based upon tapping the energy potential of a Micro Black Hole (MBH) and the Hawking radiation created by this MBH. As is well-known, the vacuum continuously produces virtual pairs of particles and antiparticles, in particular, the photons and anti-photons. The MBH event horizon allows separating them. Anti-photons can be moved to the $\mathrm{MBH}$ and be annihilated; decreasing the mass of the MBH, the resulting photons leave the MBH neighborhood as Hawking radiation. The offered nuclear generator (named by author as $\mathrm{AB}-$ Generator) utilizes the Hawking radiation and injects the matter into $\mathrm{MBH}$ and keeps MBH in a stable state with near-constant mass.

The AB-Generator can produce gigantic energy outputs and should be very small and cheaper than a conventional electric station by a factor of hundreds of times. One also may be used in aerospace as a photon rocket or as a power source for many vehicles.

Many scientists expect the Large Hadron Collider at CERN will produce one MBH every second. A technology to capture them may follow; than they may be used for the AB-Generator.
\end{abstract}

Keywords: Production of nuclear energy, Micro Black Hole, energy AB-Generator, photon rocket.

\section{Introduction}

Black hole. In general relativity, a black hole is a region of space in which the gravitational field is so powerful that nothing, including light, can escape its pull. The black hole has a one-way surface, called the event horizon, into which objects can fall, but out of which nothing can come out. It is called "black" because it absorbs all the light that hits it, reflecting nothing, just like a perfect blackbody in thermodynamics.

Despite its invisible interior, a black hole can reveal its presence through interaction with other matter. A black hole can be inferred by tracking the movement of a group of stars that orbit a region in space which looks empty. Alternatively, one can see gas falling into a relatively small black hole, from a companion star. This gas spirals inward, heating up to very high temperature and emitting large amounts of radiation that can be detected from earthbound and earth-orbiting telescopes. Such observations have resulted in the general scientific consensus that, barring a breakdown in our understanding of nature, black holes do exist in our universe.

It is impossible to directly observe a black hole. However, it is possible to infer its

\footnotetext{
* Continuation. Parts 1-3 are published in the "Intellectual Archive" Vol.7, Num 4, DOI 10.32370/2018_07_17

** Presented as Paper AIAA-2009-5342 in 45 Joint Propulsion Conferences, 2-5 August, 2009, Denver, CO, USA.
} 
presence by its gravitational action on the surrounding environment, particularly with microquasars and active galactic nuclei, where material falling into a nearby black hole is significantly heated and emits a large amount of X-ray radiation. This observation method allows astronomers to detect their existence. The only objects that agree with these observations and are consistent within the framework of general relativity are black holes. momentum.

A black hole has only three independent physical properties: mass, charge and angular In astronomy black holes are classed as:

- Supermassive - contain hundreds of thousands to billions of solar masses and are thought to exist in the center of most galaxies, including the Milky Way.

- Intermediate - contain thousands of solar masses.

- Micro (also mini black holes) - have masses much less than that of a star. At these sizes, quantum mechanics is expected to take effect. There is no known mechanism for them to form via normal processes of stellar evolution, but certain inflationary scenarios predict their production during the early stages of the evolution of the universe.

According to some theories of quantum gravity, they may also be produced in the highly energetic reaction produced by cosmic rays hitting the atmosphere or even in particle accelerators such as the Large Hadron Collider. The theory of Hawking radiation predicts that such black holes will evaporate in bright flashes of gamma radiation. NASA's Fermi Gammaray Space Telescope satellite (formerly GLAST) launched in 2008 is searching for such flashes.

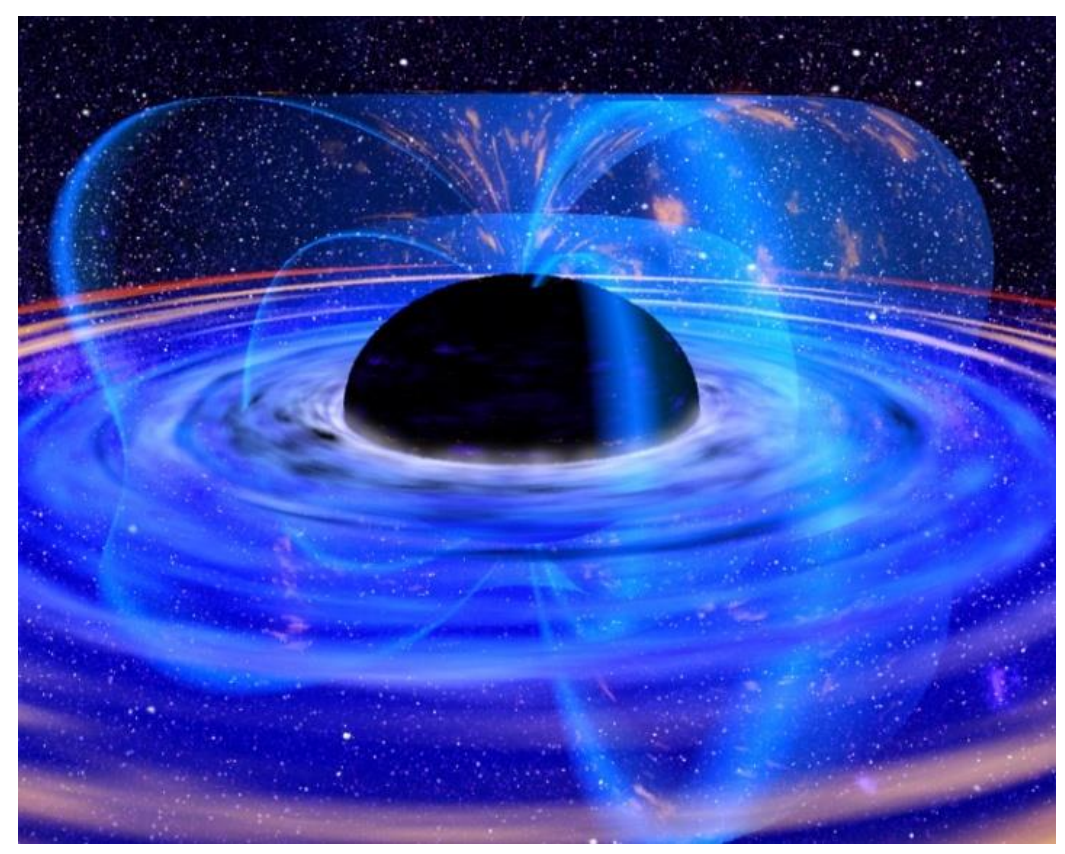

Fig 1. Artist's conception of a stellar mass NASA. 


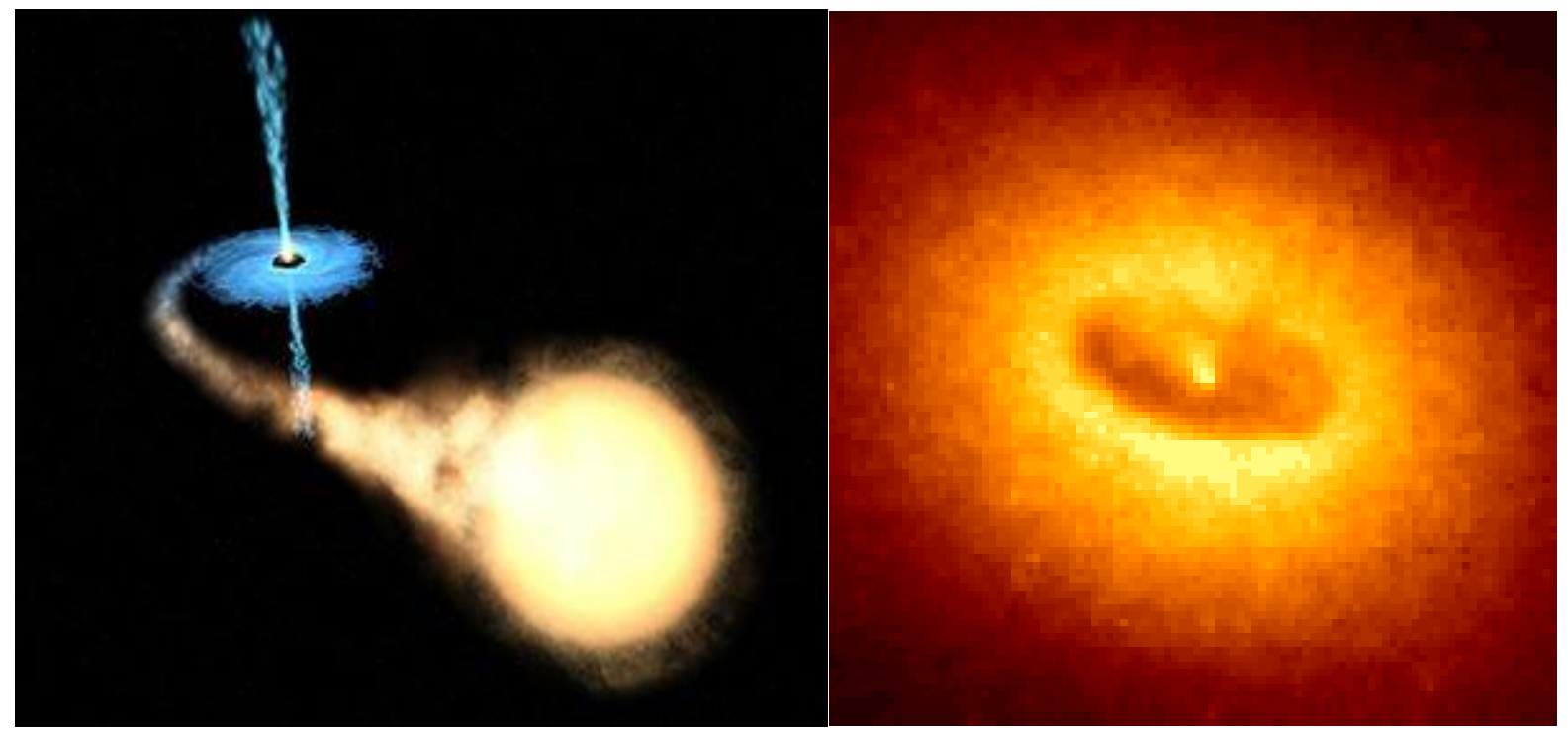

Fig.2 (left). Artist's impression of a binary system consisting of a black hole and a main sequence star. The black hole is drawing matter from the main sequence star via an accretion disk around it, and some of this matter forms a gas jet.

Fig.3 (right). Ring around a suspected black hole in galaxy NGC 4261.Date: Nov.1992. Courtesy of Space Telescope Science

The defining feature of a black hole is the appearance of an event horizon; a boundary in spacetime beyond which events cannot affect an outside observer.

Since the event horizon is not a material surface but rather merely a mathematically defined demarcation boundary, nothing prevents matter or radiation from entering a black hole, only from exiting one.

For a non-rotating (static) black hole, the Schwarzschild radius delimits a spherical event horizon. The Schwarzschild radius of an object is proportional to the mass. Rotating black holes have distorted, non-spherical event horizons. The description of black holes given by general relativity is known to be an approximation, and it is expected that quantum gravity effects become significant near the vicinity of the event horizon. This allows observations of matter in the vicinity of a black hole's event horizon to be used to indirectly study general relativity and proposed extensions to it. 


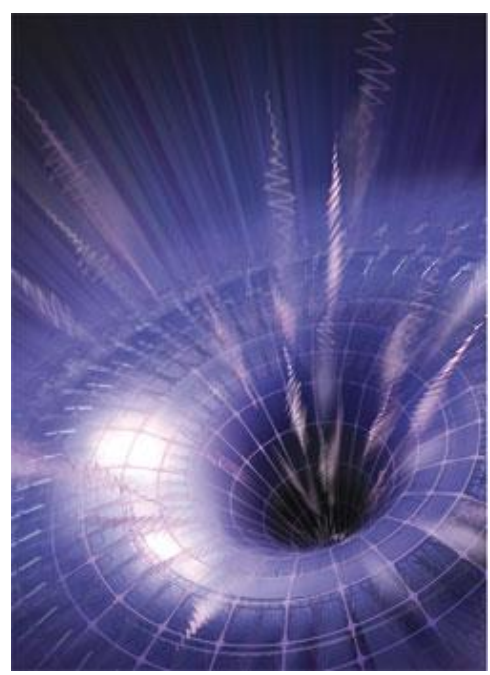

Fig.4. Artist's rendering showing the space-time contours around a black hole. Credit NASA.

Though black holes themselves may not radiate energy, electromagnetic radiation and matter particles may be radiated from just outside the event horizon via Hawking radiation. At the center of a black hole lies the singularity, where matter is crushed to infinite density, the pull of gravity is infinitely strong, and space-time has infinite curvature. This means that a black hole's mass becomes entirely compressed into a region with zero volume. This zero-volume, infinitely dense region at the center of a black hole is called a gravitational singularity.

The singularity of a non-rotating black hole has zero length, width, and height; a rotating black hole's is smeared out to form a ring shape lying in the plane of rotation. The ring still has no thickness and hence no volume.

The photon sphere is a spherical boundary of zero thickness such that photons moving along tangents to the sphere will be trapped in a circular orbit. For non-rotating black holes, the photon sphere has a radius 1.5 times the Schwarzschild radius. The orbits are dynamically unstable, hence any small perturbation (such as a particle of in falling matter) will grow over time, either setting it on an outward trajectory escaping the black hole or on an inward spiral eventually crossing the event horizon.

Rotating black holes are surrounded by a region of space-time in which it is impossible to stand still, called the ergosphere. Objects and radiation (including light) can stay in orbit within the ergosphere without falling to the center.

Once a black hole has formed, it can continue to grow by absorbing additional matter. Any black hole will continually absorb interstellar dust from its direct surroundings and omnipresent cosmic background radiation.

Much larger contributions can be obtained when a black hole merges with other stars or compact objects.

Hawking radiation. In 1974, Stephen Hawking showed that black holes are not entirely black but emit small amounts of thermal radiation. ${ }^{[1]} \mathrm{He}$ got this result by applying quantum field theory in a static black hole background. The result of his calculations is that a black hole should emit particles in a perfect black body spectrum. This effect has become 
known as Hawking radiation. Since Hawking's result many others have verified the effect through various methods. If his theory of black hole radiation is correct then black holes are expected to emit a thermal spectrum of radiation, and thereby lose mass, because according to the theory of relativity mass is just highly condensed energy $\left(E=m c^{2}\right)$. Black holes will shrink and evaporate over time. The temperature of this spectrum (Hawking temperature) is proportional to the surface gravity of the black hole, which in turn is inversely proportional to the mass. Large black holes, therefore, emit less radiation than small black holes.

On the other hand if a black hole is very small, the radiation effects are expected to become very strong. Even a black hole that is heavy compared to a human would evaporate in an instant. A black hole the weight of a car $\left(\sim 10^{-24} \mathrm{~m}\right)$ would only take a nanosecond to evaporate, during which time it would briefly have a luminosity more than 200 times that of the sun. Lighter black holes are expected to evaporate even faster, for example a black hole of mass $1 \mathrm{TeV} / c^{2}$ would take less than $10^{-88}$ seconds to evaporate completely. Of course, for such a small black hole quantum gravitation effects are expected to play an important role and could even - although current developments in quantum gravity do not indicate so - hypothetically make such a small black hole stable.

Micro Black Holes. Gravitational collapse is not the only process that could create black holes. In principle, black holes could also be created in high energy collisions that create sufficient density. Since classically black holes can take any mass, one would expect micro black holes to be created in any such process no matter how low the energy. However, to date, no such events have ever been detected either directly or indirectly as a deficiency of the mass balance in particle accelerator experiments. This suggests that there must be a lower limit for the mass of black holes.

Theoretically this boundary is expected to lie around the Planck mass $\left(\sim 10^{19} \mathrm{GeV} / \mathrm{c}^{2}\right.$, $m_{p}=2.1764 \cdot 10^{-8} \mathrm{~kg}$ ), where quantum effects are expected to make the theory of general relativity break down completely. This would put the creation of black holes firmly out of reach of any high energy process occurring on or near the Earth. Certain developments in quantum gravity however suggest that this bound could be much lower. Some brane-world scenarios for example put the Planck mass much lower, maybe even as low as $1 \mathrm{TeV}$. This would make it possible for micro black holes to be created in the high energy collisions occurring when cosmic rays hit the Earth's atmosphere, or possibly in the new Large Hadron Collider at CERN. These theories are however very speculative, and the creation of black holes in these processes is deemed unlikely by many specialists.

Smallest possible black hole. To make a black hole one must concentrate mass or energy sufficiently that the escape velocity from the region in which it is concentrated exceeds the speed of light. This condition gives the Schwarzschild radius, $r_{o}=2 G M / c^{2}$, where $G$ is Newton's constant and $c$ is the speed of light, as the size of a black hole of mass $M$. On the other hand, the Compton wavelength, $\lambda=h / M c$, where $h$ is Planck's constant, represents a limit on the minimum size of the region in which a mass $M$ at rest can be localized. For sufficiently small $M$, the Compton wavelength exceeds the Schwarzschild radius, and no black hole description exists. This smallest mass for a black hole is thus approximately the Planck mass, which is about $2 \times 10^{-8} \mathrm{~kg}$ or $1.2 \times 10^{19} \mathrm{GeV} / \mathrm{c}^{2}$.

Any primordial black holes of sufficiently low mass will Hawking evaporate to near the Planck mass within the lifetime of the universe. In this process, these small black holes radiate away 
matter. A rough picture of this is that pairs of virtual particles emerge from the vacuum near the event horizon, with one member of a pair being captured, and the other escaping the vicinity of the black hole. The net result is the black hole loses mass (due to conservation of energy). According to the formulae of black hole thermodynamics, the more the black hole loses mass the hotter it becomes, and the faster it evaporates, until it approaches the Planck mass. At this stage a black hole would have a Hawking temperature of $T_{P} / 8 \pi\left(5.6 \times 10^{32} \mathrm{~K}\right)$, which means an emitted Hawking particle would have an energy comparable to the mass of the black hole. Thus a thermodynamic description breaks down. Such a mini-black hole would also have an entropy of only $4 \pi$ nats, approximately the minimum possible value.

At this point then, the object can no longer be described as a classical black hole, and Hawking's calculations also break down. Conjectures for the final fate of the black hole include total evaporation and production of a Planck mass-sized black hole remnant. If intuitions about quantum black holes are correct, then close to the Planck mass the number of possible quantum states of the black hole is expected to become so few and so quantized that its interactions are likely to be quenched out. It is possible that such Planck-mass black holes, no longer able either to absorb energy gravitationally like a classical black hole because of the quantized gaps between their allowed energy levels, nor to emit Hawking particles for the same reason, may in effect be stable objects. They would in effect be WIMPs, weakly interacting massive particles; this could explain dark matter.

Creation of micro black holes. Production of a black hole requires concentration of mass or energy within the corresponding Schwarzschild radius. In familiar three-dimensional gravity, the minimum such energy is $10^{19} \mathrm{GeV}$, which would have to be condensed into a region of approximate size $10^{-33} \mathrm{~cm}$. This is far beyond the limits of any current technology; the Large hadron collider (LHC) has a design energy of $14 \mathrm{TeV}$. This is also beyond the range of known collisions of cosmic rays with Earth's atmosphere, which reach center of mass energies in the range of hundreds of $\mathrm{TeV}$. It is estimatedthat to collide two particles to within a distance of a Planck length with currently achievable magnetic field strengths would require a ring accelerator about 1000 light years in diameter to keep the particles on track.

Some extensions of present physics posit the existence of extra dimensions of space. In higher-dimensional space-time, the strength of gravity increases more rapidly with decreasing distance than in three dimensions. With certain special configurations of the extra dimensions, this effect can lower the Planck scale to the TeV range. Examples of such extensions include large extra dimensions, special cases of the Randall-Sundrum model, and String theory configurations. In such scenarios, black hole production could possibly be an important and observable effect at the LHC.

Virtual particles. In physics, a virtual particle is a particle that exists for a limited time and space, introducing uncertainty in their energy and momentum due to the Heisenberg Uncertainty Principle.

Vacuum energy can also be thought of in terms of virtual particles (also known as vacuum fluctuations) which are created and destroyed out of the vacuum. These particles are always created out of the vacuum in particle-antiparticle pairs, which shortly annihilate each other and disappear. However, these particles and antiparticles may interact with others before disappearing.

The net energy of the Universe remains zero so long as the particle pairs annihilate 
each other within Planck time.

Virtual particles are also excitations of the underlying fields, but are detectable only as forces.

The creation of these virtual particles near the event horizon of a black hole has been hypothesized by physicist Stephen Hawking to be a mechanism for the eventual "evaporation" of black holes.

Since these particles do not have a permanent existence, they are called virtual particles or vacuum fluctuations of vacuum energy.

An important example of the "presence" of virtual particles in a vacuum is the Casimir effect. Here, the explanation of the effect requires that the total energy of all of the virtual particles in a vacuum can be added together. Thus, although the virtual particles themselves are not directly observable in the laboratory, they do leave an observable effect: their zero-point energy results in forces acting on suitably arranged metal plates or dielectrics.

Thus, virtual particles are often popularly described as coming in pairs, a particle and antiparticle, which can be of any kind.

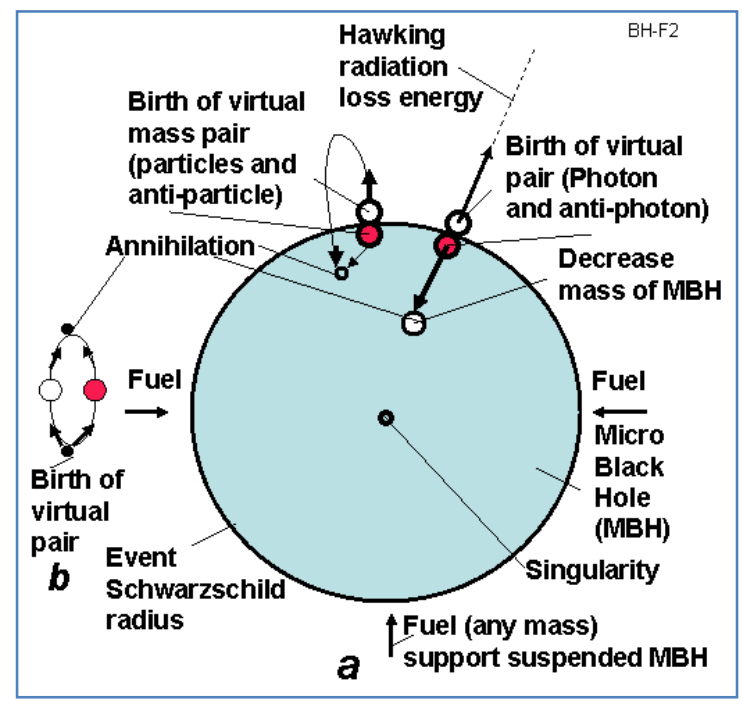

Fig.5. Hawking radiation.

$\boldsymbol{a}$. Virtual particles at events horizon. $\boldsymbol{b}$. Virtual particles out events horizon (in conventional space).

The evaporation of a black hole is a process dominated by photons, which are their own antiparticles and are uncharged.

The uncertainty principle in the form $\Delta E \Delta t \geq \hbar$ implies that in the vacuum one or more particles with energy $\Delta E$ above the vacuum may be created for a short time $\Delta t$. These virtual particles are included in the definition of the vacuum.

Vacuum energy is an underlying background energy that exists in space even when devoid of matter (known as free space). The vacuum energy is deduced from the concept of virtual particles, which are themselves derived from the energy-time uncertainty principle. Its effects can be observed in various phenomena (such as spontaneous emission, the Casimir 
effect, the van der Waals bonds, or the Lamb shift), and it is thought to have consequences for the behavior of the Universe on cosmological scales.

\section{AB-Generator of Nuclear Energy and some Innovations}

Simplified explanation of MBH radiation and work of AB-Generator (Fig.5). As known, the vacuum continuously produces, virtual pairs of particles and antiparticles, in particular, photons and anti-photons. In conventional space they exist only for a very short time, then annihilate and return back to nothingness. The $\mathrm{MBH}$ event horizon, having very strong super-gravity, allows separation of the particles and anti-particles, in particular, photons and anti-photons. Part of the anti-photons move into the $\mathrm{MBH}$ and annihilate with photons decreasing the mass of the $\mathrm{MBH}$ and return back a borrow energy to vacuum. The free photons leave from the $\mathrm{MBH}$ neighborhood as Hawking radiation. That way the $\mathrm{MBH}$ converts any conventional matter to Hawking radiation which may be converted to heat or electric energy by the AB-Generator. This AB- Generator utilizes the produced Hawking radiation and injects the matter into the $\mathrm{MBH}$ while maintaining the $\mathrm{MBH}$ in stable suspended state. Note: The photon does NOT have rest mass. Therefore a photon can leave the MBH's neighborhood (if it is located beyond the event horizon). All other particles having a rest mass and speed less than light speed cannot leave the Black Hole. They cannot achieve light speed because their mass at light speed equals infinity and requests infinite energy for its' escapean impossibility.

Description of AB- Generator. The offered nuclear energy AB- Generator is shown in fig. 6. That includes the Micro Black Hole $(\mathrm{MBH}) 1$ suspended within a spherical radiation reflector and heater 5. The MBH is supported (and controlled) at the center of sphere by a fuel (plasma, proton, electron, matter) gun 7. This AB- Generator also contains the 9 - heat engine (for example, gas, vapor turbine), 10 - electric generator, 11 - coolant (heat transfer agent), an outer electric line 12, internal electric generator ( 5 as antenna) with customer 14.

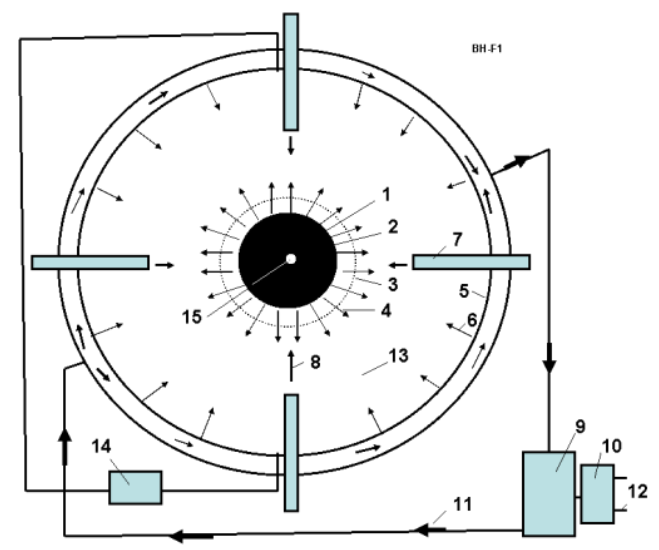

Fig.6. Offered nuclear-vacuum energy AB- Generator. Notations: 1- Micro Black Hole (MBH), 2 event horizon (Schwarzschild radius), 3 - photon sphere, 4 - black hole radiation, 5 - radiation reflector, antenna and heater (cover sphere), 6 - back (reflected) radiation from radiation reflector 5, 7 - fuel (plasma, protons, electrons, ions, matter) gun (focusing accelerator), 8 - matter injected to MBH (fuel for Micro Black hole), 9 - heat engine (for example, gas, vapor turbine), 10 - electric generator 
connected to heat engine 9,11 - coolant (heat transfer agent to the heat machine 9), 12 - electric line, 13 - internal vacuum, 14 - customer of electricity from antenna 5, 15 - singularity.

Work. The generator works the following way. $\mathrm{MBH}$, by selective directional input of matter, is levitated in captivity and produces radiation energy 4. That radiation heats the spherical reflector-heater 5 . The coolant (heat transfer agent) 11 delivers the heat to a heat machine 9 (for example, gas, vapor turbine). The heat machine rotates an electric generator 10 that produces the electricity to the outer electric line 12. Part of $\mathrm{MBH}$ radiation may accept by sphere 5 (as antenna) in form of electricity.

The control fuel guns inject the matter into $\mathrm{MBH}$ and do not allow bursting of the $\mathrm{MBH}$. This action also supports the $\mathrm{MBH}$ in isolation, suspended from dangerous contact with conventional matter. They also control the MBH size and the energy output.

Any matter may be used as the fuel, for example, accelerated plasma, ions, protons, electrons, micro particles, etc. The MBH may be charged and rotated. In this case the MBH may has an additional suspension by control charges located at the ends of fuel guns or (in case of the rotating charged $\mathrm{MBH}$ ) may have an additional suspension by the control electric magnets located on the ends of fuel guns or at points along the reflector-heater sphere.

\section{Innovations, features, advantages and same research results}

Some problems and solutions offered by the author include the following:

1) A practical (the MBH being obtained and levitated, details of which are beyond the scope of this paper) method and installation for converting any conventional matter to energy in accordance with Einstein's equation $E=m c^{2}$.

2) MBHs may produce gigantic energy and this energy is in the form of dangerous gamma radiation.

The author shows how this dangerous gamma radiation Doppler shifts when it moves against the $\mathrm{MBH}$ gravity and converts to safely tapped short radio waves.

3) The MBH of marginal mass has a tendency to explode (through quantum evaporation, very quickly radiating its mass in energy). The AB- Generator automatically injects metered amounts of matter into the $\mathrm{MBH}$ and keeps the $\mathrm{MGH}$ in a stable state or grows the $\mathrm{MBH}$ to a needed size, or decreases that size, or temporarily turns off the AB-Generator (decreases the $\mathrm{MBH}$ to a Planck Black Hole).

4) Author shows the radiation flux exposure of $\mathrm{AB}$ - Generator (as result of $\mathrm{MBH}$ exposure) is not dangerous because the generator cover sphere has a vacuum, and the MBH gravity gradient decreases the radiation energy.

5) The MBH may be supported in a levitated (non-contact) state by generator fuel injectors.

\section{Theory of AB- Generator}

Below there are main equations for computation the conventional black hole (BH) and ABGenerator.

General theory of Black Hole.

1. Power produced by $\mathrm{BH}$ is

$$
P=\frac{\hbar c^{6}}{15360 \pi G^{2}} \frac{1}{M^{2}} \approx 3.56 \cdot 10^{32} \frac{1}{M^{2}}, \quad \mathrm{~W},
$$


where $\hbar=h / 2 \pi=1.0546 \cdot 10^{-34} \mathrm{~J} / \mathrm{s}$ is reduced Planck constant, $c=3 \cdot 10^{8} \mathrm{~m} / \mathrm{s}$ - light speed, $G=6.6743 \cdot 10^{-11} \mathrm{~m}^{3} / \mathrm{kg} . \mathrm{s}^{2}$ is gravitation constant, $M-$ mass of $\mathrm{BH}, \mathrm{kg}$.

2. Temperature of black body corresponding to this radiation is

$$
T=\frac{\hbar c^{3}}{8 \pi G k_{b}} \frac{1}{M} \approx 1.23 \cdot 10^{23} \frac{1}{M}, \mathrm{~K},
$$

where $k_{b}=1.38 .10^{-23} \mathrm{~J} / \mathrm{k}$ is Boltzmann constant.

3. Energy $E_{p}[\mathrm{~J}]$ and frequency $v_{\mathrm{o}}$ of photon at event horizon are

$$
E_{p}=\frac{h c^{3}}{16 \pi G} \frac{1}{M}, \quad v_{0}=\frac{E_{p}}{h}=\frac{c^{3}}{16 \pi G} \frac{1}{M}=8.037 \cdot 10^{33} \frac{1}{M}, \quad \lambda_{0}=\frac{c}{v_{0}}=3.73 \cdot 10^{-26} M .
$$

where $c=3 \cdot 10^{8} \mathrm{~m} / \mathrm{s}$ is light speed, $\lambda_{\mathrm{o}}$ is wavelength of photon at even radius, $\mathrm{m} . h$ is Planck constant.

4. Radius of $\mathrm{BH}$ event horizon (Schwarzschild radius) is

$$
r_{0}=\frac{2 G}{c^{2}} M=1.48 \cdot 10^{-27} M, \quad \mathrm{~m},
$$

5. Relative density (ratio of mass $M$ to volume $V$ of $\mathrm{BH}$ ) is

$$
\rho=\frac{M}{V}=\frac{3 c^{2}}{32 \pi G^{3}} \frac{1}{M^{2}} \approx 7.33 \cdot 10^{79} \frac{1}{M^{2}}, \quad \mathrm{~kg} / \mathrm{m}^{3} .
$$

6. Maximal charge of $\mathrm{BH}$ is

$$
Q_{\max }=5 \cdot 10^{9} e M \approx 8 \cdot 10^{-10} M, \quad \mathrm{C},
$$

where $e=-1.6 \cdot 10^{-19}$ is charge of electron, C.

7. Life time of $\mathrm{BH}$ is

$$
\tau=\frac{5120 \pi G^{2}}{\hbar c^{4}} M^{3}=2.527 \cdot 10^{-8} M^{3}, s .
$$

8. Gravitation around $\mathrm{BH}$ ( $r$ is distance from center) and on event horizon

$$
g=\frac{G M}{r^{2}}, \quad g_{0}=\frac{c^{4}}{4 G} \frac{1}{M}=3 \cdot 10^{42} \frac{1}{M}, \quad \mathrm{~m} \mathrm{~s}^{-2} .
$$

\section{Developed Theory of AB-Generator}

Below are research and the theory developed by author for estimation and computation of facets of the AB-Generator.

9. Loss of energy of Hawking photon in BH gravitational field. It is known the theory of a redshift allows estimating the frequency of photon in central gravitational field when it moves TO the gravity center. In this case the photon increases its frequency because photon is accelerated the gravitational field (wavelength decreases). But in our case the photon moves FROM the gravitational center, the gravitational field brakes it and the photon loses its energy. That means its frequency decreases and the wavelength increases. Our photon gets double energy because the black hole annihilates two photons (photon and anti-photon). That way the equation for photon frequency at distance $r>r_{\mathrm{o}}$ from center we can write in form 


$$
\frac{v}{v_{0}} \approx 1+\frac{2 \Delta \varphi}{c^{2}},
$$

Where $\Delta \varphi=\varphi-\varphi_{0}$ is difference of the gravity potential. The gravity potential is

$$
\Delta \varphi=\varphi-\varphi_{0}, \quad \varphi=\frac{G M}{r}, \quad \varphi_{0}=\frac{G M}{r_{0}}, \quad r_{0}=\frac{2 G M}{c^{2}} .
$$

Let us substitute (10) in (9), we get

$$
\frac{v}{v_{0}} \approx 1+\frac{r_{0}}{r}-\frac{r_{0}}{r_{0}}, \quad \text { or } \quad \frac{v}{v_{0}}=\frac{\lambda_{0}}{\lambda} \approx \frac{r_{0}}{r} .
$$

It is known, the energy and mass of photon is

$$
E_{f}=\hbar \gamma, \quad E_{f}=m_{f} c^{2}, \quad m_{f}=E_{f} / c^{2},
$$

The energy of photon linear depends from its frequency. Reminder: The photon does not have a rest mass.

The relative loss of the photon radiation energy $\xi$ at distance $r$ from $\mathrm{BH}$ and the power $P_{r}$ of Hawking radiation at radius $r$ from the $\mathrm{BH}$ center is

$$
\xi=\frac{r_{0}}{r}, \quad v=\xi v_{0}, \quad P_{r}=\xi P .
$$

The $r_{\mathrm{o}}$ is very small and $\xi$ is also very small and $v<<v_{\mathrm{o}}$.

The result of an energy loss by Hawking photon in the $\mathrm{BH}$ gravitational field is very important for AB-Generator. The energy of Hawking radiation is very big; we very need to decrease it in many orders. The initial Hawking photon is gamma radiation that is dangerous for people and matter. In $r$ distance the gamma radiation may be converted in the conventional light or radio radiation, which are not dangerous and may be reflected, focused or a straightforward way converted into electricity by antenna.

10. Reflection Hawking radiation back to $\mathrm{MBH}$. For further decreasing the $\mathrm{MBH}$ produced energy the part of this energy may be reflected to back in MBH. A conventional mirror may reflect up $0.9 \div 0.99$ of radiation $\left(\xi_{r}=0.01 \div 0.1, \xi_{r}\right.$ is a loss of energy in reflecting), the multi layers mirror can reflect up 0.9999 of the monochromatic light radiation $\left(\xi_{r}=10^{-3} \div 10^{-5}\right)$, and AB-mirror from cubic corner cells offered by author in [2], p. 226, fig.12.1g, p. 376 allows to reflect non-monochromatic light radiation with efficiency up $\xi_{r}=10^{-13}$ strong back to source. In the last case, the loss of reflected energy is ([2] p.377)

$$
\xi_{r}=0.00023 a l, \quad l=m \lambda, \quad m \geq 1,
$$

where $l$ is size of cube corner cell, $\mathrm{m} ; m$ is number of radiation waves in one sell; $\lambda$ is wavelength, $\mathrm{m}$; $a$ is characteristic of sell material (see [2], fig.A3.3). Minimal value $a=10^{-2}$ for glass and $a=10^{-4}$ for $\mathrm{KCl}$ crystal.

The reflection of radiation to back in $\mathrm{MBH}$ is may be important for $\mathrm{MBH}$ stabilization, $\mathrm{MBH}$ storage and $\mathrm{MBH}$ 'switch off'.

11. Useful energy of AB- Generator. The useful energy $P_{u}[\mathrm{~J}]$ is taken from AB- Generator is

$$
P_{u}=\xi \xi_{r} P
$$

\section{Fuel consumptionis}

$$
\dot{M}=P_{u} / c^{2}, \quad \mathrm{~kg} .
$$

The fuel consumption is very small. AB-Generator is the single known method in 
the World now which allows full converting reasonably practical conversion of (any!) matter into energy according the Einsteinian equation $E=m c^{2}$.

13. Specific pressure on AB-Generator cover sphere $p\left[\mathrm{~N} / \mathrm{m}^{2}\right]$ and on the surface of MBH $p_{\mathrm{o}}$ is

$p=\frac{k P_{r}}{S c}=\frac{k P_{r}}{4 \pi r^{2} c}=2.65 \cdot 10^{-10} \frac{k P_{r}}{r^{2}}, \quad p_{0}=\frac{P}{S_{0} c}=\frac{\hbar c^{9}}{15360 \cdot 16 \pi^{2} G^{4}} \frac{1}{M^{4}}=8.57 \cdot 10^{76} \frac{1}{M^{4}}$,

(17) where $k=1$ if the cover sphere absorbs the radiation and $k \approx 2$ if the cover sphere high reflects the radiation, $S$ is the internal area of cover sphere, $\mathrm{m}^{2} ; S_{0}$ is surface of event horizon sphere, $\mathrm{m}^{2} ; p_{\mathrm{o}}$ is specific pressure of Hawking radiation on the event horizon surface. Note, the pressure $p$ on cover sphere is small (see Project), but pressure $p_{\mathrm{o}}$ on event horizon surface is very high.

14. Mass particles produced on event surface. On event horizon surface may be also produced the mass particles with speed $V<c$. Let us take the best case (for leaving the $\mathrm{BH}$ ) when their speed is radially vertical. They cannot leave the BH because their speed $V$ is less than light speed $c$. The maximal radius of lifting $r_{m}[\mathrm{~m}]$ is

$$
d V=-g d t, \quad d V=-\frac{g}{V} d r=-\frac{G M}{V} \frac{d r}{r^{2}}, \quad r_{m}=\frac{2 G M}{c^{2}-V_{0}^{2}}=\frac{r_{0}}{1-(V / c)^{2}},
$$

where $g$ is gravitational acceleration of $\mathrm{BH}, \mathrm{m} / \mathrm{s}^{2} ; t$ is time, sec.; $r_{\mathrm{o}}$ is $\mathrm{BH}$ radius, $\mathrm{m} ; V_{0}$ is particle speed on event surface, $\mathrm{m} / \mathrm{s}^{2}$. If the $r_{m}$ is less than radius of the cover sphere, the mass particles return to $\mathrm{BH}$ and do not influence the heat flow from $\mathrm{BH}$ to cover sphere. That is in the majority of cases.

15.Explosion of MBH. The MBH explosion produces the radiation energy

$$
E_{e}=M c^{2} \text {. }
$$

MBH has a small mass. The explosion of MBH having $M=10^{-5} \mathrm{~kg}$ produces $9 \times 10^{11} \mathrm{~J}$. That is energy of about 10 tons of good conventional explosive $\left(10^{7} \mathrm{~J} / \mathrm{kg}\right)$. But there is a vacuum into the cover sphere and this energy is presented in radiation form. But in reality only very small part of explosion energy reaches the cover sphere, because the very strong MBH gravitation field brakes the photons and any mass particles. Find the energy which reaches the cover sphere via:

$d E=\xi c^{2} d M, \quad \xi=\frac{r_{0}}{r}, \quad r_{0}=\frac{2 G}{c^{2}} M, \quad d E=\frac{2 G}{r} M d M, \quad E=\frac{G}{r} M^{2}=6,674 \cdot 10^{-11} \frac{M^{2}}{r}$.

The specific exposure radiation pressure of $\mathrm{MBH}$ pressure $p_{e}\left[\mathrm{~N} / \mathrm{m}^{2}\right]$ on the cover sphere of radius $r<r_{\mathrm{o}}$ may be computed by the way:

$p_{e}=\frac{E}{V}=\frac{3 G}{4 \pi} \frac{M^{2}}{r^{3}}=1.6 \cdot 10^{-11} \frac{M^{2}}{r^{3}}, \quad r>r_{0}$,

where $V=3 / 4 \pi r^{3}$ is volume of the cover sphere.

That way the exposure radiation pressure on sphere has very small value and presses very short time. Conventional gas balloon keeps pressure up $10^{7} \mathrm{~N} / \mathrm{m}^{2}$ (100 atm). However, the heat impact may be high and AB- Generator design may have the reflectivity cover and automatically open windows for radiation.

Your attention is requested toward the next important result following from equations 
(20)-(21). Many astronomers try to find (detect) the MBH by a MBH exposure radiation. But this radiation is small, may be detected but for a short distance, does not have a specific frequency and has a variably long wavelength. This may be why during more than 30 years nobody has successfully observed $\mathrm{MBH}$ events in Earth environment though the theoretical estimation predicts about 100 of $\mathrm{MBH}$ events annually. Observers take note!

16. Supporting the MBH in suspended (levitated) state. The fuel injector can support the $\mathrm{MBH}$ in suspended state (no contact the MBH with any material surface).

The maximal suspended force equals

$$
F=q V_{f}, \quad q=\frac{P_{u}}{c^{2}}, \quad F=\frac{P_{u} V_{f}}{c^{2}},
$$

where $q$ is fuel consumption, $\mathrm{kg} ; V_{f}$ is a fuel speed, $\mathrm{m} / \mathrm{s}$. The fuel (plasma) speed $0.01 \mathrm{cis}$ conventionally enough for supporting the $\mathrm{MBH}$ in suspended state.

17. AB-Generator as electric generator. When the Hawking radiation reaches the cover as radio microwaves they may be straightforwardly converted to electricity because they create a different voltage between different isolated parts of the cover sphere as in an antenna. Maximal voltage which can produces the radiation wave is

$$
w=\frac{\varepsilon \varepsilon_{0} E^{2}}{2}+\frac{\mu \mu_{0} H^{2}}{2}, \quad w=\frac{P_{r}}{c},
$$

where $w$ is density of radiation energy, $\mathrm{J} / \mathrm{m}^{3} ; E$ is electric intensity, $\mathrm{V} / \mathrm{m} ; H$ is magnetic intensity, $\mathrm{T} ; \varepsilon_{\mathrm{o}}=8.85 \times 10^{-12} \mathrm{~F} / \mathrm{m}$ is the coefficient of the electric permeability; $\mu_{\mathrm{o}}=4 \pi \times 10^{-7}$ $\mathrm{N} / \mathrm{A}^{2}$ is the coefficient of the magnetic permeability; $\varepsilon=\mu=1$ for vacuum.

Let us take moment when $H=0$, then

$$
\begin{aligned}
& E=\sqrt{\frac{2 w}{\varepsilon_{0}}}=\sqrt{\frac{2 P_{r}}{\varepsilon_{0} c}}=2.73 \sqrt{P_{r}} \quad U \approx b \pi D E, \quad b=\frac{\pi D}{0.5 \lambda} \leq 1, \\
& P_{e} \approx b P_{r}, \quad \lambda=\lambda_{0} \frac{r}{r_{0}}=16 r, \quad b=\frac{4 \pi r}{16 r}=\frac{\pi}{4},
\end{aligned}
$$

where $E$ is electric intensity, $\mathrm{V} / \mathrm{m} ; U$ is voltage of $\mathrm{AB}$-generator, $\mathrm{V} ; b$ is relative size of antenna, $D$ is diameter of the cover sphere if the cover sphere is used as a full antenna, $\mathrm{m} ; P_{e}$ is power of the electric station, W.

As you see about $\pi / 4$ of total energy produced by AB-Generator we can receive in the form of electricity and $(1-\pi / 4)$ reflects back to $\mathrm{MBH}$; we may tap heat energy which convert to any form of energy by conventional (heat engine) methods. If we reflect the most part of the heat energy back into the $\mathrm{MBH}$, we can have only electricity and do not have heat flux. If we will use the super strong and super high temperature material AB-material offered in [3] the conversion coefficient of heat machine may be very high.

18. Critical mass of MBH located in matter environment. Many people are afraid the MBH experiments because $\mathrm{BH}$ can absorb the Earth. Let us find the critical mass of MBH which can begin uncontrollably to grow into the Earth environment. That will happen when $\mathrm{BH}$ begins to have more mass than mass of Hawking radiation. Below is the equation for the critical mass of initial BH. The educated reader will understand the equations below without detailed explanations. 


$$
\begin{aligned}
& d V=g d t, \quad g=\frac{G M}{r^{2}}, \quad d t=\frac{d r}{V}, \quad V d V=g d r, \quad \int_{V}^{c} V d V=\int_{r}^{r_{o}} \frac{G M}{r^{2}} d r, \quad r_{0}=\frac{2 G}{c^{2}} M, \quad V^{2}=c^{2} \frac{r_{0}}{r}, \\
& V=c \sqrt{\frac{r_{0}}{r}}, \quad d t=\frac{\sqrt{r} d r}{c \sqrt{r_{0}}}, \quad \int_{t}^{0} d t=\frac{1}{c \sqrt{r_{0}}} \int_{r}^{r_{o}} \sqrt{r} d r, \quad t=\frac{2}{3 c \sqrt{r_{0}}}\left(r^{3 / 2}-r_{0}^{3 / 2}\right) \approx \frac{2 r^{3 / 2}}{3 c r_{0}^{1 / 2}}, \quad r=\left(\frac{3 c \sqrt{r_{0}}}{2} t\right)^{3 / 2}, \\
& r=1.65 G^{1 / 2} M^{1 / 3} t^{2 / 3}, \quad \dot{M}=\frac{P}{c^{2}}=\frac{\hbar c^{4}}{15360 \pi G^{2}} \frac{1}{M^{2}}=4 \cdot 10^{15} \frac{1}{M^{2}}, \quad \text { for } \quad t=1 s, \\
& \dot{M}_{c}=\frac{4}{3} \pi r^{3} \gamma=6 \pi \gamma G^{3 / 2} M \approx 10^{-4} \gamma M, \quad M=M_{c} e^{6 \pi / G^{3 / 2}} \approx M_{c} e^{10^{-4} \gamma t}, \quad t=\frac{1}{6 \pi \gamma G^{3 / 2}} \ln \frac{M}{M_{c}} \approx \frac{10^{4}}{\gamma} \ln \frac{M}{M_{c}},
\end{aligned}
$$

where $\mathrm{V}$ is speed of environment matter absorbed by $\mathrm{MBH}, \mathrm{m} / \mathrm{s}$; $\mathrm{g}$ is gravity acceleration of $\mathrm{MBH}, \mathrm{m} / \mathrm{s} ; \mathrm{r}$ is distance environment matter to $\mathrm{MBH}$ center, $\mathrm{m}$; $\mathrm{t}$ is time, sec; $\dot{M}$ is mass loss by $\mathrm{MBH}, \mathrm{kg} ; \dot{M}_{c}$ is mass taken from Earth environment by $\mathrm{MBH}, \mathrm{kg} ; \gamma$ is density of Earth environment, $\mathrm{kg} / \mathrm{m} 3$; Mc is critical mass of $\mathrm{MBH}$ when one begin uncontrollable grows, $\mathrm{kg}$; $\mathrm{t}$ is time, sec.

Let us to equate the mass $\dot{M}$ radiated by $\mathrm{MBH}$ to mass $\dot{M}_{c}$ absorbed by $\mathrm{MBH}$ from Earth environment, we obtain the critical mass $\mathrm{Mc}$ of $\mathrm{MBH}$ for any environment:

$$
M_{c}^{3}=\frac{\hbar c^{4}}{92160 \pi^{2} G^{3}} \frac{1}{\gamma}=3.17 \cdot 10^{24} \frac{1}{\gamma}, \quad \text { or } \quad \gamma=3.17 \cdot 10^{24} \frac{1}{M_{c}^{3}},
$$

If $\mathrm{MBH}$ having mass $M=10^{7} \mathrm{~kg}$ (10 thousands tons) is put in water $\left(\gamma=1000 \mathrm{~kg} / \mathrm{m}^{3}\right)$, this $\mathrm{MBH}$ can begin uncontrollable runaway growth and in short time ( $74 \mathrm{sec})$ can consume the Earth into a black hole having diameter $\sim 9 \mathrm{~mm}$. If this $\mathrm{MBH}$ is located in the sea level atmosphere $\left(\gamma=1.29 \mathrm{~kg} / \mathrm{m}^{3}\right)$, the initial MBH must has critical mass $M=10^{8} \mathrm{~kg}$ (100 thousand tons). The critical radius of $\mathrm{MBH}$ is very small. In the first case $\left(M=10^{7} \mathrm{~kg}\right) r_{\mathrm{o}}=1.48 \times 10^{-20}$ $\mathrm{m}$, in the second case $\left(M=10^{8} \mathrm{~kg}\right) r_{\mathrm{o}}=1.48 \times 10^{-19} \mathrm{~m}$. Our MBH into AB-Generator is not dangerous for Earth because it is located in vacuum and has mass thousands to millions times less than the critical mass.

However, in a moment of extreme speculation, if far future artificial intelligence (or super-small reasoning) beings will be created from nuclear matter [3] they can convert the Earth into a black hole to attempt to access quick travel to other stars (Solar systems), past and future Universes and even possibly past and future times.

19. General note. We got our equations in assumption $\lambda / \lambda_{o}=r / r_{o}$. If $\lambda / \lambda_{o}=\left(r / r_{o}\right)^{0.5}$ or other relation, the all above equations may be easy modified.

\section{AB-Generator as Photon Rocket}

The offered AB- Generator may be usedas the most efficient photon propulsion system (photon rocket). The photon rocket is the dream of all astronauts and space engineers, a unique vehicle, which would make practical interstellar travel. But a functioning photon rocket would require gigantic energy. The AB- Generator can convert any matter in energy (radiation) and gives the maximum theoretical efficiency.

The some possible photon propulsion system used the $\mathrm{AB}-$ Generator is shown in 
Fig.7. In simplest version $(\boldsymbol{a})$ the cover of $\mathrm{AB}$ generator has window 3, the radiation goes out through window and produces the thrust. More complex version $(\boldsymbol{c})$ has the parabolic reflector, which sends all radiation in one direction and increases the efficiency. If an insert in the ABGenerator covers the lens 6 which will focuses the radiation in a given direction, at the given point the temperature will be a billions degree (see Equation (2)) and AB-Generator may be used as a photon weapon.

The maximal thrust $T$ of the photon engine having AB- Generator may be computed (estimated) by equation: $T=\dot{M} c, \quad \mathrm{~N}$,

For example, the AB-generator, which spends only 1 gram of matter per second, will produce a thrust $3 \times 10^{5} \mathrm{~N}$ or 30 tons.

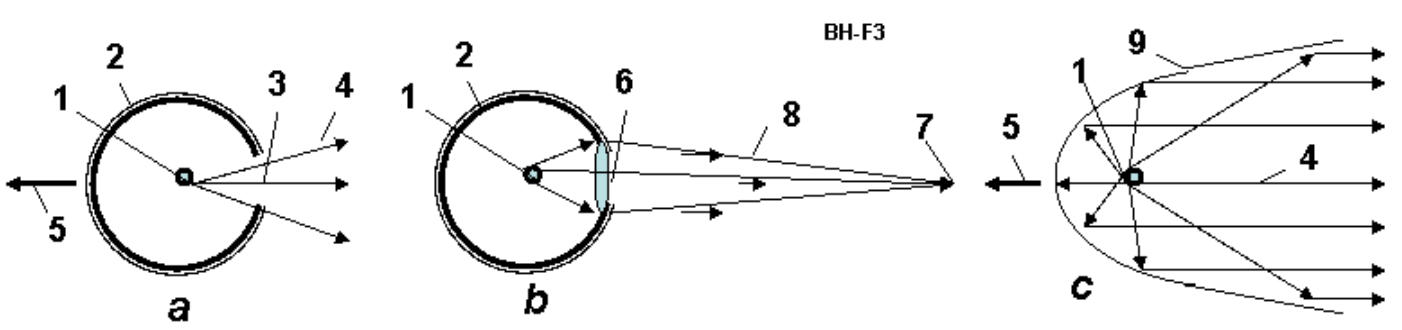

Fig.7. AB- Generator as Photon Rocket and Radiation (Photon) Weapon. (a) AB- Generator as a Simplest Photon Rocket; (b) AB- Generator as focused Radiation (photon, light or laser) weapon; (c) Photon Rocket with Micro-Black Hole of AB-Generator. Notations: 1 - control $\mathrm{MBH} ; 2$ - spherical cover of AB-Generator; 3 - window in spherical cover; 4 - radiation of $\mathrm{BH} ; 5$ - thrust; 6 - lens in window of cover; 7 - aim; 8 - focused radiation; 9 - parabolic reflector.

\section{Short information of Photon Rockets and relativistic flight.}

A photon rocket is a hypothetical rocket that uses thrust from emitted photons (radiation pressure by emission) for its propulsion [2].

Photons could be generated by onboard generators, as in the nuclear photonic rocket.

The speed an ideal photon rocket will reach, in the absence of external forces, depends on the ratio of its initial and final mass:

$$
v=c \frac{\left(m_{i} / m_{f}\right)^{2}-1}{\left(m_{i} / m_{f}\right)^{2}+1},
$$

where $m_{i}$ is the initial mass and $m_{f}$ is the final mass: $c=3 \cdot 10^{8} \mathrm{~m} / \mathrm{s}$ is light speed The gamma factorcorresponding to this speed has the simple expression:

$$
\gamma=0.5\left(m_{i} / m_{f}+m_{f} / m_{i}\right)
$$

The Lorentz factor or Lorentz term is the factor by which time, length, and relativistic mass change for an object while that object is moving. The expression appears in several equations in special relativity, and it arises in derivations of the Lorentz transformations.

The Lorentz factor is defined as [2]

$$
\gamma=\frac{1}{\sqrt{1-v^{2} / c^{2}}}=\frac{1}{\sqrt{1-\beta^{2}}}=\frac{d t}{d \tau}
$$


where: $v$ is the relative velocity between inertial reference frames, $\beta$ is the ratio of $v$ to the speed of light $c, \tau$ is the proper time for an observer (measuring time intervals in the observer's own frame), $t$ is coordinate time, $c=3 \cdot 10^{8} \mathrm{~m} / \mathrm{s}$ is the speed of light in a vacuum.

The Lorentz transformation: The simplest case is a boost in the $x$-direction, which describes how space-time coordinates change from one inertial frame using coordinates $(x, y$, $z, t)$ to another $\left(x^{\prime}, y^{\prime}, z^{\prime}, t^{\prime}\right)$ with relative velocity $v$ :

$$
t^{\prime}=\gamma\left(t-\frac{v x}{c^{2}}\right), \quad x^{\prime}=\gamma(x-v t)
$$

Corollaries of the above transformations are the results:

Time dilation: The time $\left(\Delta t^{\prime}\right)$ between two ticks as measured in the frame in which the clock is moving, is longer than the time $(\Delta t)$ between these ticks as measured in the rest frame of the clock:

$$
\Delta t^{\prime}=\gamma \Delta t
$$

Length contraction: The length $\left(\Delta x^{\prime}\right)$ of an object as measured in the frame in which it is moving, is shorter than its length $(\Delta x)$ in its own rest frame:

$$
\Delta x^{\prime}=\Delta x / \gamma \text {. }
$$

Applying conservation of momentum and energy leads to these results:

Relativistic mass: The mass of an object $m$ in motion is dependent on $\gamma_{\text {and }}$ the rest mass $m_{0}$ :

$$
m=\gamma m_{0} \text {. }
$$

Relativistic momentum: The relativistic momentum relation takes the same form as for classical momentum, but using the above relativistic mass:

$$
\vec{p}=m \vec{v}=\gamma m_{0} \vec{v}
$$

Relativistic kinetic energy: The relativistic kinetic energy relation takes the slightly modified form:

$$
E_{k}=E-E_{0}=(\gamma-1) m_{0} c^{2}
$$

\section{Speed (units of c) Lorentz factor Reciprocal}

$\begin{array}{ccc}\beta=v / c & \gamma & 1 / \gamma \\ 0.100 & 1.005 & 0.995 \\ 0.150 & 1.011 & 0.989 \\ 0.200 & 1.021 & 0.980 \\ 0.900 & 2.294 & 0.436 \\ 0.990 & 7.089 & 0.141 \\ 0.999 & 22.366 & 0.045\end{array}$

The Lorentz factor has the Maclaurin series:

$$
\gamma=\frac{1}{\sqrt{1-\beta^{2}}} \approx 1+\frac{1}{2} \beta^{2}+\ldots
$$

which is a special case of a binomial series.

The approximation $\gamma \approx 1+{ }^{1} / 2 \beta^{2}$ may be used to calculate relativistic effects at low speeds. It holds to within $1 \%$ error for $v<0.4 \mathrm{c}(v<120,000 \mathrm{~km} / \mathrm{s})$, and to within $0.1 \%$ error for $v<0.22$ $c(v<66,000 \mathrm{~km} / \mathrm{s})$. 
The truncated versions of this series also allow physicists to prove that special relativity reduces to Newtonian mechanics at low speeds. For example, in special relativity, the following two equations hold:

$$
\vec{p}=\gamma m \vec{v}, E=\gamma m c^{2}
$$

For $\gamma \approx 1$ and $\gamma \approx 1+{ }_{1}^{1} / 2 \beta^{2}$, respectively, these reduce to their Newtonian equivalents:

$$
\vec{p}=m \vec{v} \quad E=m c^{2}+\frac{1}{2} m v^{2} \text {. }
$$

The Lorentz factor equation can also be inverted to yield:

$$
\beta=\sqrt{1-\frac{1}{\gamma^{2}}}
$$

This has an asymptotic form of:

$$
\beta=1-\frac{1}{2} \gamma^{-2}-\frac{1}{8} \gamma^{-4}-\frac{1}{16} \gamma^{-6}-\frac{5}{128} \gamma^{-8}+\cdots \text { (40) }
$$

The first two terms are occasionally used to quickly calculate velocities from large $\gamma$ values. The approximation $\beta \approx 1-1 / 2 \gamma^{-2}$ holds to within $1 \%$ tolerance for $\gamma>2$, and to within $0.1 \%$ tolerance for $\gamma>3.5$.

\section{Project of AB-Generator for Photon Rocket}

Let us to estimate the possible energy production of an AB-Generator. That is not optimal, that is example of computation and possible parameters. Let us take the MBH mass $M=10^{-5} \mathrm{~kg}$ and radius of the cover sphere $r=5 \mathrm{~m}$. No reflection. Using the equations (1)-(24) we receive:

$$
\begin{aligned}
& P=3.56 \cdot 10^{32} / M^{2}=3,56 \cdot 10^{42} \mathrm{~W}, \\
& r_{0}=1.48 \cdot 10^{-27} M=1.48 \cdot 10^{-32} \mathrm{~m}, \\
& \xi=r_{0} / r=2.96 \cdot 10^{-33}, \\
& P_{r}=\xi P=1.05 \cdot 10^{10}, \quad P_{u}=\xi \xi_{r} P=P_{r}, \quad \mathrm{~W}, \quad \xi_{r}=1 . \\
& \lambda_{0}=3,73 \cdot 10^{-26} M=3.73 \cdot 10^{-31} \mathrm{~m} . \\
& \lambda=16 \cdot r=80 \quad \mathrm{~m} . \\
& p=\frac{P_{r}}{4 \pi c r^{2}}=0.111 \quad \frac{N}{m^{2}}, \quad c=3 \cdot 10^{8} \quad \mathrm{~m} / \mathrm{s}, \\
& \dot{M}=P_{u} / c^{2}=1.17 \cdot 10^{-7} \quad \mathrm{~kg} / \mathrm{s}, \\
& p_{e}=1.6 \cdot 10^{-11} \frac{M^{2}}{r^{3}}=1.28 \cdot 10^{-23} \quad \mathrm{~N} / \mathrm{m}^{2}
\end{aligned}
$$

Remain the main notations in equations (27): $P_{r}=P_{u}=1.05 \times 10^{10} \mathrm{~W}$ is the useful energy ( $\pi / 4$ of this energy may be taken as electric energy by cover antenna, the rest is taken as heat); $\lambda=80 \mathrm{~m}$ is wavelength of radiation at cover sphere (that is not dangerous for people); $\dot{M}=1.17 \times 10^{-7} \mathrm{~kg} / \mathrm{s}$ is fuel consumption; $r_{o}=1.48 \times 10^{-32} \mathrm{~m}$ is radius of $\mathrm{MBH} ; p_{e}=1.28 \times 10^{-23}$ $\mathrm{N} / \mathrm{m}^{2}$ is explosion pressure of $\mathrm{MBH}$.

Look your attention - the explode pressure is very small. That is less in billions of time then radiation pressure on the cover surface $p=0.111 \mathrm{~N} / \mathrm{m}^{2}$. That is no wonder because $\mathrm{BH}$ takes back the energy with that spent for acceleration the matter in eating the matter. No dangerous from explosion of $\mathrm{MBH}$. 
Heat transfer and internal electric power are

$q=\frac{P_{u}}{S}=\frac{P_{u}}{4 \pi r^{2}}=3.34 \cdot 10^{7} \quad \frac{\mathrm{W}}{\mathrm{m}^{2}}$,

For $\delta=2 \cdot 10^{-3} \mathrm{~m}, \quad \lambda_{h}=100, \Delta T \approx q \delta / \lambda_{h}=668^{\circ} \mathrm{K}$,

$E=2.73 \sqrt{P_{r}}=2.8 \cdot 10^{5} \quad \mathrm{~V} / \mathrm{m}, \quad U=E \cdot 2 r=2.8 \cdot 10^{6} \quad \mathrm{~V}, \quad P_{e}=P_{r} / 8=1.31 \cdot 10^{9} \quad \mathrm{~W}$,

where $q$ is specific heat transfer through the cover sphere, $S$ is internal surface of the cover sphere, $\mathrm{m}^{2} ; \delta$ is thickness of the cover sphere wall, $\mathrm{m} ; \lambda_{h}$ is heat transfer coefficient for steel; $\Delta T$ is difference temperature between internal and external walls of the cover sphere; $E$ is electric intensity from radiation on cover sphere surface, $\mathrm{V} / \mathrm{m} ; U$ is maximal electric voltage, $\mathrm{V} ; P_{e}$ is electric power, $\mathrm{W}$.

We get the power heat and electric output of a $\mathrm{AB}-$ Generator as similar to a very large complex of present day Earth's electric power stations $\left(P_{r}=10^{10} \mathrm{~W}\right.$, ten billion of watts). The $\mathrm{AB}-G e n e r a t o r$ is cheaper by a hundred times than a conventional electric station, especially since, we may reflect a heat energy back to the $\mathrm{MBH}$ and not built a heat engine with all the problems of conventional power conversion equipment (using only electricity from spherical cover as antenna).

We hope the Large Hadron Collider at CERN can get the initial MBH needed for ABGenerator. The other way to obtain one is to find the Planck MBH (remaining from the time of the Big Bang and former $\mathrm{MBH}$ ) and grow them to target $\mathrm{MBH}$ size.

\section{Results}

1. Author has offered the method and installation for converting any conventional matter to energy according the Einstein's equation $E=m c^{2}$, where $m$ is mass of matter, $\mathrm{kg} ; c=3 \cdot 10^{8}$ is light speed, $\mathrm{m} / \mathrm{s}$.

2. The Micro Black Hole $(\mathrm{MBH})$ is offered for this conversion.

3. Also is offered the control fuel guns and radiation reflector for explosion prevention of $\mathrm{MBH}$.

4. Also is offered the control fuel guns and radiation reflector for the $\mathrm{MBH}$ control.

5. Also is offered the control fuel guns and radiation reflector for non-contact suspension (levitation) of the $\mathrm{MBH}$.

6. For non-contact levitation of $\mathrm{MBH}$ the author also offers:

a) Controlled charging of $\mathrm{MBH}$ and of ends of the fuel guns.

b) Control charging of rotating $\mathrm{MBH}$ and control of electric magnets located on the ends of the fuel guns or out of the reflector-heater sphere.

7. The author researches show the very important fact: A strong gamma radiation produced by Hawking radiation loses energy after passing through the very strong gravitational $\mathrm{MBH}$ field. The $\mathrm{MBH}$ radiation can reach the reflector-heater as the light or short-wave radio radiation. That is very important for safety of the operating crew of the AB- Generator. 8. The author researches show: The matter particles produced by the MBH cannot escape from $\mathrm{MBH}$ and cannot influence the Hawking radiation.

9. The author researches show another very important fact: The MBH explosion (hundreds and thousands of TNT tons) in radiation form produces a small pressure on the reflector-heater (cover sphere) and does not destroys the AB-generator (in a correct design of $\mathrm{AB}$ generator!). That is very important for safety of the operating crew of the AB-generator. 
10. The author researches show another very important fact: the MBH cannot capture by oneself the surrounding matter and cannot automatically grow to consume the planet. 11. As the initial MBH can be used the Planck's (quantum) MBH which may be everywhere.

The offered fuel gun may to grow them (or decrease them) to needed size or the initial MBH may be used the MBH produce Large Hadron Collider (LHC) at CERN. Some scientists assume LHC will produce one MBH every second (86,400 MBH in day). The cosmic radiation also produces about $100 \mathrm{MBH}$ every year.

12. The spherical dome of MBH may convert part of the radiation energy to electricity.

13. A correct design of $\mathrm{MBH}$ generator does not produce the radioactive waste of environment.

14. The attempts of many astronomers find (detect) the $\mathrm{MBH}$ by a MBH exposure radiation will not be successful without knowing the following: The MBH radiation is small, may be detected only over a short distance, does not have specific frequency and has a variable long wavelength.

\section{Discussion}

We got our equations in assumption $\lambda / \lambda_{o}=r / r_{o}$. If $\lambda / \lambda_{o}=\left(r / r_{o}\right)^{0.5}$ or other relation, the all above equations may be easy modified.

The Hawking article was published 34 years ago (1974) [1]. After this time the hundreds of scientific works based in Hawking work appears. No facts are known which creates doubts in the possibility of Hawking radiation but it is not proven either. The Hawking radiation may not exist. The Large Hadron Collider has the main purpose to create the MBHs and detect the Hawking radiation.

\section{Conclusion}

The AB-Generator could create a revolution in many industries (electricity, car, ship, transportation, etc.). That allows designing photon rockets and flight to other star systems. The maximum possible efficiency is obtained and a full solution possible for the energy problem of humanity. These overwhelming prospects urge us to research and develop this achievement of science [1]-[5].

\section{General Discussing Parts 1-4}

Interstellar flight is impossible at current time. It is in some orders more difficult than trip to Mars. The sending of small probe to the nearest star systems "Alfa-Centauri"requests gigantic energy (about 100 powerful electric station), expensive equipment (hundreds of billions dollars $)$ and large trip time $(30 \div 40$ years $)$. The conventional nuclear and thermonuclear on-board reactors cannot also solve this problem. Weare hoping to find an advanced civilization that will move our technology leap. But we do not know: there is platens at nearest star systems having conditions closed to our Earth? Is there a life on these planets? What is level of their development? If they are above us, why do not they came to us, or at least do not send signals to us?

There are many sceptic questions. But we do not must wait, we must develop our science and technology. Early or later we reach a level when human/robot civilization colonize not only our galactic but all Universe and will create the new Universe and new intelligent civilization, higher mind [ 1-2]. 


\section{References}

\section{References to Part 4}

(The reader may find some of related articles http://viXra.org/abs/1604.0304;

https://achive.org/details/List5.2OfBolonkinPublication42216; http://arxiv.org, http://aiaa.org search "Bolonkin"; and in the author's books: "Non-Rocket Space Launch and Flight", Elsevier, London, 2006, 488 pages; "New Concepts, Ideas, Innovations in Aerospace, Technology and Human Science", NOVA, 2008, 502 pages and "Macro-Projects: Environment and Technology", NOVA 2009, 536 pages).

1. Hawking, S.W. (1974), "Black hole explosions?", Nature 248: 30-31, doi:10.1038/248030a0, http://www.nature.com/nature/journal/v248/n5443/abs/248030a0.html.

2. Bolonkin A.A., Non-Rocket Space Launch and Flight, Elsevier, 2006, 488 pgs. ISBN-13: 978-008044-731-5, ISBN-10: 0-080-44731-7. https://archive.org/details/Non-rocketSpaceLaunchAndFlightv.3 , (v.3), http://vixra.org/abs/1407.0174.http://Bolonkin.narod.ru/p65.htm .

3. Bolonkin A.A., Converting of Matter to Nuclear Energy by AB-Generator. American Journal of Enginering and Applied Sciences. 2 (2), 2009, p.683-693. [on line], http://viXra.org/abs/1401.0173, http://www.archive.org/details/FemtotechnologyDesignOfTheStrongestAb-matterForAerospace,

4. Bolonkin A.A., Femtotechnology. Nuclear AB-Matter with Fantastic Properties, American Journal of Enginering and Applied Sciences. 2 (2), 2009, p.501-514. [On line]:See also closed paper AIAA2010-1556 in 48 Aerospace Meeting, New Horizons, 4 - 7 January, 2010, Orlando, FL, USA. Global Science Journal http://gsjournal.net/Science-Journals/Research\%20PapersEngineering\%20\%28Applied\%29/Download/5713. Journal of Aerospace Engineering, Oct. 2010, Vol. 23, No. 4, pp.281-292.http://viXra.org/abs/1401.0173,http://viXra.org/abs/1309.0201, http://www.archive.org/details/FemtotechnologyDesignOfTheStrongestAb-matterForAerospace,

5. Wikipedia. Some background material about Black Holes in this article is gathered from Wikipedia under the Creative Commons license. http://wikipedia.org .

\section{References for General Discussing}

1. Bolonkin A.A.,Human Immortality and Electronic Civilization. Lulu, USA, $3^{\text {rd }}$ edition (in English), 2007.

http://www.archive.org/details/HumanImmortalityAndElectronicCivilization , http://Vixra.org/abs/0709.0001, https://www.academia.edu/11001577/Human_Immortality_and_Electronic_Civilization_USA_New_ York_2007.

2.Bolonkin A.A.,"New Concepts, Ideas, Innovations in Aerospace, Technology and the Human Sciences”, NOVA, 2006, 510 pgs. ISBN-13: 978-1-60021-787-6. http://viXra.org/abs/1309.0193, http://www.archive.org/details/NewConceptsIfeasAndInnovationsInAerospaceTechnologyAndHuma nSciences 


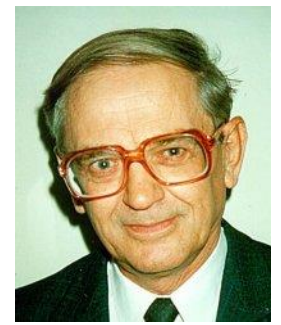

\section{Short biography of Bolonkin, Alexander Alexandrovich}

Alexander A. Bolonkin was born in the former USSR. He holds doctoral degree in aviation engineering from Moscow Aviation Institute and a post-doctoral degree in aerospace engineering from Leningrad Polytechnic University. He has held the positions of senior engineer in the Antonov Aircraft Design Company and Chairman of the Reliability Department in the Clushko Rocket Design Company. He has also lectured at the Moscow Aviation Universities. Following his arrival in the United States in 1988, he lectured at the New Jersey Institute of Technology and worked as a Senior Scientist at NASA and the US Air Force Research Laboratories.

Bolonkin is the author of more than 250 scientific articles and books and has 17 inventions to his credit. His most notable books include The Development of Soviet Rocket Engines (Delphic Ass., Inc., Washington , 1991); Non-Rocket Space Launch and Flight (Elsevier, 2006); New Concepts, Ideas, Innovation in Aerospace, Technology and Human Life (USA, NOVA, 2007); Macro-Projects: Environment and Technology (NOVA, 2008); Human Immortality and Electronic Civilization, 3-rd Edition, (Lulu, 2007; Publish America, 2010):Life and Science. Lambert Academic Publishing, Germany, 2011, 205 pgs. ISBN: 978-3-8473-0839-3.

http://www.archive.org/details/Life.Science.Future.biographyNotesResearchesAndInnovations;

Homepage: http://Bolonkin.narod.ru 


\title{
Benford's Law in Information Science \\ Yuri N. Klimov, Oleg N. Klimov \\ Moscow, Russia \\ E-mail: yuri.klimov.29@mail.ru
}

\begin{abstract}
For the first time, Benford's law is confirmed for computer science and refined by simple algebraic equations for dynamics and cumulative number of digits. For the first time it is also shown by simple algebraic equations the difference of dynamics and cumulates for the relative and relative exponential rates of change $F(n)$ or the probability to meet the figure of the first. Benford's law on lexicology is closer to the quantitative characteristics we have studied in the field of Informatics and other fields of knowledge about the Universe, i.e. it is a universal law.
\end{abstract}

Keywords: Benford's law, information's science, mathematical modeling

Закон Бенфорда или закон первой цифры гласит, что в таблицах чисел, основанных на данных источников из реальной жизни, цифра 1 на первом месте встречается гораздо чаще, чем все остальные (рис. 1). Более того, чем больше цифра, тем меньше вероятности, что она будет стоять в числе на первом месте [1 http://baguzin.ru/wp/zakon-benforda-ili-zakon-pervoj-tsifry/].

\begin{tabular}{|r|r|}
\hline Переая цифра & Вероятность \\
\hline 1 & $30,1 \%$ \\
\hline 2 & $17,6 \%$ \\
\hline 3 & $12,5 \%$ \\
\hline 4 & $9,7 \%$ \\
\hline 5 & $7,9 \%$ \\
\hline 6 & $6,7 \%$ \\
\hline 7 & $5,8 \%$ \\
\hline 8 & $5,1 \%$ \\
\hline 9 & $4,6 \%$ \\
\hline
\end{tabular}

Рис. 1. Вероятность встретить первую цифру в данных из источников реальной жизни

Например, если подсчитать, с какой частотой встречаются первые цифры в числах, являющихся степенью двойки, то закономерность будет почти такой же (рис. 2). Аналогично ведут себя и числа Фибоначчи и чуть менее «красиво» факториалы (см. лист «рис. 2» Excel-файла). Закону Бенфорда подчиняются числа из многих областей, к примеру, из области финансов. В действительности, закон как нельзя лучше подходит для обработки большого массива финансовых показателей на предмет мошенничества. Закон Бенфорда применим к множествам чисел, которые могут расти экспоненциально 
(другими словами, темп роста величины пропорционален её текущему значению). Например, счета за электричество, остатки товаров на складах, цены на акции, численность населения, смертность, длины рек, площади стран, высоты самых высоких сооружений в мире. Закон обычно не действует для распределений с заданными минимальными или максимальными значениями (список компаний с доходом от 50000 до 100000 долларов). Также не подходит нормальное распределение и распределения, охватывающие только один или два порядка величин (IQ взрослых). Закон Бенфорда не применим к множеству букв (но, например, к словам применим закон Ципфа). Объём данных должен быть достаточен для применения статистических методов.

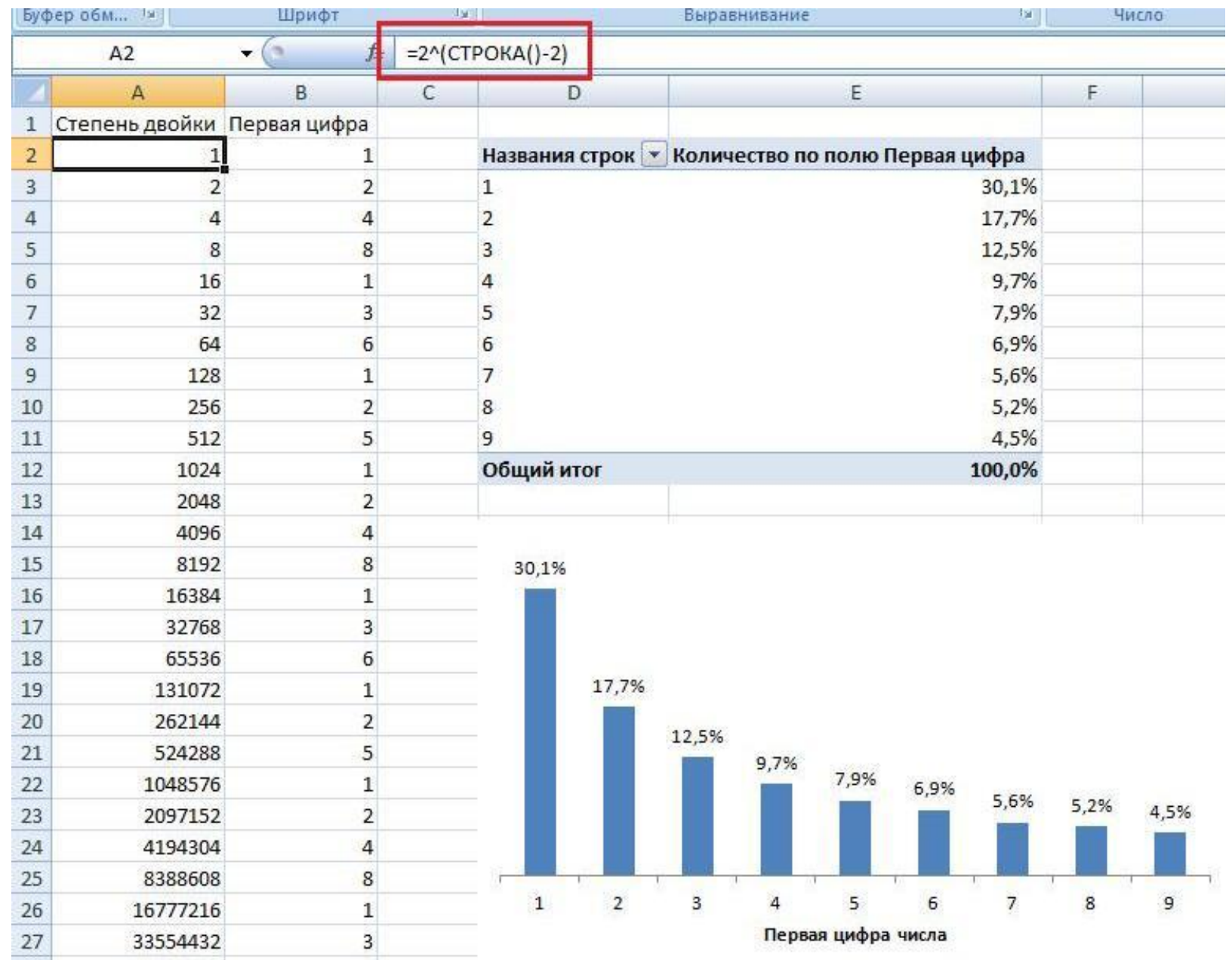

Рис. 2. Первая цифра в числах, являющихся степенью двойки, для диапазона от $2^{0}$ до $2^{1000}$

Форма Закона Бенфорда может быть объяснена, если предположить, что равномерно распределены логарифмы чисел; например, вероятность нахождения числа между 100 и 1000 (логарифм между 2 и 3) является такой же, как и между 10000 и 100 000 (логарифм между 4 и 5). Для множества чисел, особенно имеющих 
экспоненциальный рост, таких как доходы или цены на бирже, это разумное предположение. Закон Бенфорда выполняется для всех процессов, имеющих фрактальную природу (Б Мандельброт. (Не) послушные рынки: фрактальная революция в финансах). Для того чтобы установить явный вид функции $F(n)$, удовлетворяющей закону Бенфорда, рассмотрим переменную величину $G(t)$, растушую по показательному (экспоненциальному) закону [2]. Время, за которое $\mathrm{G}(t)$ возрастает от 1 до 10, примем за единицу времени; тогда $G(t)=10^{\mathrm{t}}$. Разделим интервал $[0,1]$ на отрезки, внутри которых значения $G(t)$ заключены между последовательными целыми числами. Их границами служат точки $\lg 1=0, \lg 2, \lg 3 \ldots . . \lg 9, \lg 10=1$ (рис. 3 ).

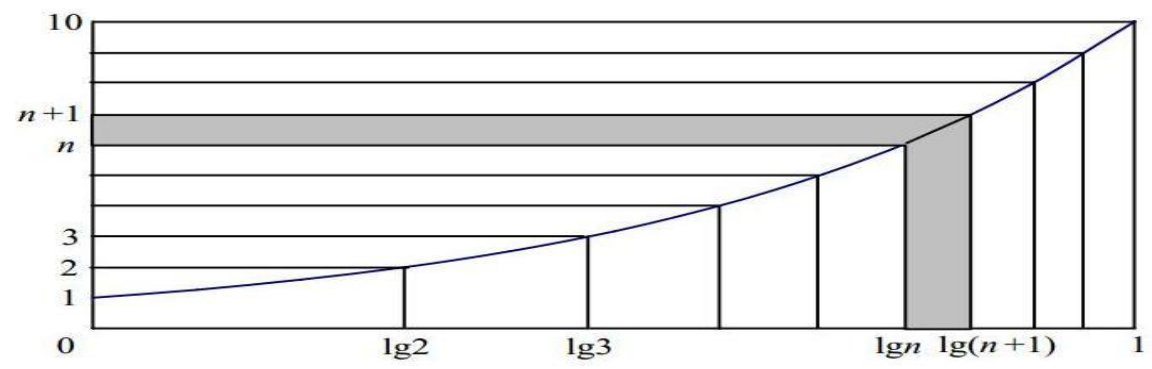

Рис. 3. Объяснение закона Бенфорда

Когда $G(t)$ нарастёт до 10 , примем эту десятку за новую единицу измерения, а текущее время - за новое начало отсчета; при этом процесс нарастания $G(t)$ в следующем разряде от новой единицы до новой десятки каждый раз будет описываться одной и той же формулой. Вероятность обнаружить величину $G$ в таком состоянии, что её первая цифра равна $n$, равна длине $n$-ого отрезка:

$$
F(n)=\lg (n+1)-\lg (n)=\lg \left(\frac{n+1}{n}\right)=\lg \left(1+\frac{1}{n}\right)
$$

Значения $F(n)$, вычисленные по этой формуле, приведены в таблице:

Значение $F(n)$ или вероятность встретить цифру

$\begin{array}{cc}\text { Первая цифра } & \text { первой } \\ 1 & 30,103 \% \\ 2 & 17,609 \% \\ 3 & 12,494 \% \\ 4 & 9,691 \% \\ 5 & 7,918 \% \\ 6 & 6,695 \% \\ 7 & 5,799 \%\end{array}$


Предыдущее описание приведено по работе [1 http://baguzin.ru/wp/zakon-benfordaili-zakon-pervoj-tsifry/].

Выльигается гипотеза о применимости закона Бенфорда для уточнения вероятности встретить первую иифру в данных и описания простыми алгебраическими уравнениями.

Приведем наши численные данные в области информатики [2]:

- Потоки научно-технической информации;

- Динамика публикаций в Chemical Abstracts (1907-2003)

- Динамика патентов в Chemical Abstracts (1907-2003) ;

- Динамика книг в Chemical Abstracts (1907-2003) ;

- Динамика рефератов в Chemical Abstracts (1907-2003);

- Динамика рефератов в РЖ ВИНИТИ РАН ,«Химия» ;

- Динамика английских слогов по Ципфу [6]: ;

- Динамика латинских слогов у Плавта по Ципфу, 1935. [6]: .

Значение $F(n)$ или вероятность встретить цифру первой, вычисленные по этой формуле, приведены в табл. 1-8.

Таблица 1. Информатика, Потоки

\begin{tabular}{|c|c|c|c|c|}
\hline $\begin{array}{l}\text { Информатика, } \\
\text { Потоки } \\
\text { Первая цифра }\end{array}$ & $\begin{array}{c}\text { Динамика } \\
\text { чисел }\end{array}$ & $\begin{array}{c}\text { Значение } F(n) \text {, } \\
\text { или вероятность } \\
\text { встретить цифру } \\
\text { первой }\end{array}$ & $\begin{array}{c}\text { Кумулятивные } \\
\text { числа }\end{array}$ & $\begin{array}{c}\text { Значение } F(n) \text {, } \\
\text { или вероятность } \\
\text { встретить цифру } \\
\text { первой }\end{array}$ \\
\hline 1 & 2 & $30,103 \%$ & 2 & $30,103 \%$ \\
\hline 2 & 1 & $17,609 \%$ & 3 & $47,712 \%$ \\
\hline 3 & 0 & $12,494 \%$ & 3 & $60,206 \%$ \\
\hline 4 & 0 & $9,691 \%$ & 3 & $69,897 \%$ \\
\hline
\end{tabular}




\begin{tabular}{|c|c|c|c|c|}
\hline 5 & 1 & $7,918 \%$ & 4 & $77,815 \%$ \\
\hline 6 & 1 & $6,695 \%$ & 5 & $84,510 \%$ \\
\hline 7 & 1 & $5,799 \%$ & 6 & $90,309 \%$ \\
\hline 8 & 1 & $5,115 \%$ & 7 & $95,424 \%$ \\
\hline 9 & 2 & $4,576 \%$ & 9 & $100,000 \%$ \\
\hline & 9 & $100,000 \%$ & & \\
\hline
\end{tabular}

Таблица 2. Динамика публикаций в Chemical Abstracts 1907-2003)

\begin{tabular}{|c|c|c|c|c|}
\hline $\begin{array}{c}\text { Динамика } \\
\text { публикаций в } \\
\text { CAS } \\
\text { (1907-2003) } \\
\text { Первая цифра }\end{array}$ & $\begin{array}{c}\text { Динамика } \\
\text { чисел }\end{array}$ & $\begin{array}{c}\text { Значение } F(n) \text {, } \\
\text { или вероятность } \\
\text { встретить цифру } \\
\text { первой }\end{array}$ & $\begin{array}{c}\text { Кумулятивные } \\
\text { числа }\end{array}$ & $\begin{array}{c}\text { Значение } F(n) \text {, } \\
\text { или вероятность } \\
\text { встретить цифру } \\
\text { первой }\end{array}$ \\
\hline 1 & 23 & $30,103 \%$ & 23 & $30,103 \%$ \\
\hline 2 & 15 & $17,609 \%$ & 38 & $47,712 \%$ \\
\hline 3 & 26 & $12,494 \%$ & 64 & $60,206 \%$ \\
\hline 4 & 11 & $9,691 \%$ & 75 & $69,897 \%$ \\
\hline 5 & 9 & $7,918 \%$ & 84 & $77,815 \%$ \\
\hline 6 & 5 & $6,695 \%$ & 89 & $84,510 \%$ \\
\hline 7 & 3 & $5,799 \%$ & 92 & $90,309 \%$ \\
\hline 8 & 1 & $5,115 \%$ & 93 & $95,424 \%$ \\
\hline 9 & 3 & $4,576 \%$ & 96 & $100,000 \%$ \\
\hline & 96 & $100,000 \%$ & & \\
\hline
\end{tabular}


Таблица 3. Динамика патентов в Chemical Abstracts (1907-2003)

\begin{tabular}{|c|c|c|c|c|}
\hline $\begin{array}{c}\text { Динамика } \\
\text { патентов в } \\
\text { CAS } \\
\text { (1907-2003) } \\
\text { Первая цифра }\end{array}$ & $\begin{array}{l}\text { Динамика } \\
\text { чисел }\end{array}$ & $\begin{array}{c}\text { Значение } F(n) \text {, } \\
\text { или вероятность } \\
\text { встретить цифру } \\
\text { первой }\end{array}$ & $\begin{array}{c}\text { Кумулятивные } \\
\text { числа }\end{array}$ & $\begin{array}{c}\text { Значение } F(n) \text {, } \\
\text { или вероятность } \\
\text { встретить цифру } \\
\text { первой }\end{array}$ \\
\hline 1 & 29 & $30,103 \%$ & 29 & $30,10 \%$ \\
\hline 2 & 13 & $17,609 \%$ & 42 & $47,712 \%$ \\
\hline 3 & 9 & $12,494 \%$ & 51 & $60,206 \%$ \\
\hline 4 & 8 & $9,691 \%$ & 59 & $69,897 \%$ \\
\hline 5 & 10 & $7,918 \%$ & 69 & $77,815 \%$ \\
\hline 6 & 7 & $6,695 \%$ & 76 & $84,510 \%$ \\
\hline 7 & 9 & $5,799 \%$ & 85 & $90,309 \%$ \\
\hline 8 & 6 & $5,115 \%$ & 91 & $95,424 \%$ \\
\hline \multirow[t]{2}{*}{9} & 6 & $4,576 \%$ & 97 & $100,000 \%$ \\
\hline & 97 & $100,000 \%$ & & \\
\hline
\end{tabular}

Таблица 4. Динамика книг в Chemical Abstracts (1907-2003)

\begin{tabular}{|c|c|c|c|c|}
\hline $\begin{array}{c}\text { Динамика книг в } \\
\text { ПАS (19 7-2003) }\end{array}$ & $\begin{array}{c}\text { Значение } F(n), \\
\text { или вероятность } \\
\text { встретить цифру } \\
\text { первой }\end{array}$ & $\begin{array}{c}\text { Кумулятивные } \\
\text { чисел }\end{array}$ & $\begin{array}{c}\text { Значение } F(n), \\
\text { или вероятность } \\
\text { встретить цифру } \\
\text { первой }\end{array}$ \\
\hline 1 & 33 & $30,103 \%$ & 33 & $30,103 \%$ \\
\hline 2 & 11 & $17,609 \%$ & 44 & $47,712 \%$ \\
\hline 3 & 14 & $12,494 \%$ & 58 & $60,206 \%$ \\
\hline 4 & 8 & $9,691 \%$ & 66 & $69,897 \%$ \\
\hline 5 & 13 & $7,918 \%$ & 79 & $87,815 \%$ \\
\hline 6 & 6 & $6,695 \%$ & 85 & $8,510 \%$ \\
\hline
\end{tabular}




\begin{tabular}{|l|c|c|c|c|}
\hline 7 & 5 & $5,799 \%$ & 90 & $90,309 \%$ \\
\hline 8 & 3 & $5,115 \%$ & 93 & $95,424 \%$ \\
\hline & 93 & $100,000 \%$ & & \\
\hline
\end{tabular}

Таблица 5. Динамика рефератов в Chemical Abstracts (1907-2003)

\begin{tabular}{|c|c|c|c|c|}
\hline $\begin{array}{l}\text { Динамика } \\
\text { рефератов в } \\
\text { CAS (1907-2003) } \\
\text { Первая цифра }\end{array}$ & $\begin{array}{l}\text { Динамика } \\
\text { чисел }\end{array}$ & $\begin{array}{c}\text { Значение } F(n) \text { или } \\
\text { вероятность встретить } \\
\text { цифру первой }\end{array}$ & $\begin{array}{l}\text { Кумулятивые } \\
\text { числа }\end{array}$ & $\begin{array}{l}\text { Значение } F(n) \text {, } \\
\text { или вероятность } \\
\text { встретить } \\
\text { цифру первой }\end{array}$ \\
\hline 1 & 19 & $30,103 \%$ & 19 & $30,10 \%$ \\
\hline 2 & 14 & $17,609 \%$ & 33 & $47,712 \%$ \\
\hline 3 & 12 & $12,494 \%$ & 45 & $60,206 \%$ \\
\hline 4 & 19 & $9,691 \%$ & 64 & $69,897 \%$ \\
\hline 5 & 10 & $7,918 \%$ & 74 & $77,815 \%$ \\
\hline 6 & 11 & $6,695 \%$ & 85 & $84,510 \%$ \\
\hline 7 & 7 & $5,799 \%$ & 92 & $90,309 \%$ \\
\hline 8 & 4 & $5,115 \%$ & 96 & $95,424 \%$ \\
\hline \multirow[t]{2}{*}{9} & 1 & $4,576 \%$ & 97 & $100,000 \%$ \\
\hline & 97 & $100,000 \%$ & & \\
\hline
\end{tabular}

Таблица 6. Динамика рефератов в РЖ «Химия» ВИНИТИ РАН

\begin{tabular}{|c|c|c|c|c|}
\hline $\begin{array}{c}\text { Динамика } \\
\text { реферато в в } \\
\text { РЖ «Химия» } \\
\begin{array}{c}\text { Первая } \\
\text { цифра }\end{array}\end{array}$ & Динамика. & $\begin{array}{l}\text { Значение } F(n) \text { или } \\
\text { вероятность } \\
\text { встретить цифру } \\
\text { первой }\end{array}$ & $\begin{array}{c}\text { Кумулятивные } \\
\text { числа }\end{array}$ & $\begin{array}{c}\text { Значение } F(n) \\
\text { встретить цифрость } \\
\text { первой }\end{array}$ \\
\hline 1 & 40 & $30,103 \%$ & 40 & $30,10 \%$ \\
\hline 2 & 4 & $17,609 \%$ & 44 & $47,712 \%$ \\
\hline
\end{tabular}




\begin{tabular}{|c|c|c|c|c|}
\hline 3 & 0 & $12,494 \%$ & 44 & $60,206 \%$ \\
\hline 4 & 1 & $9,691 \%$ & 45 & $69,897 \%$ \\
\hline 5 & 1 & $7,918 \%$ & 46 & $77,815 \%$ \\
\hline 6 & 0 & $6,695 \%$ & 46 & $84,510 \%$ \\
\hline 7 & 1 & $5,799 \%$ & 47 & $90,309 \%$ \\
\hline 8 & 3 & $5,115 \%$ & 50 & $100,000 \%$ \\
\hline 9 & 1 & $4,576 \%$ & 51 & \\
\hline & 51 & $100,000 \%$ & & \\
\hline
\end{tabular}

Таблица 7. Динамика английских слогов по Ципфу

\begin{tabular}{|c|c|c|c|c|}
\hline \\
\hline $\begin{array}{l}\text { Динамика } \\
\text { английских } \\
\text { слогов по } \\
\text { Ципфу } \\
\text { Первая цифра }\end{array}$ & $\begin{array}{c}\text { Динамика } \\
\text { чисел }\end{array}$ & $\begin{array}{l}\text { Значение } F(n) \text {, } \\
\text { или вероятность } \\
\text { встретить цифру } \\
\text { первой }\end{array}$ & $\begin{array}{c}\text { Кумулятивные } \\
\text { числа }\end{array}$ & $\begin{array}{c}\text { Значение } F(n) \text {, } \\
\text { или вероятность } \\
\text { встретить цифру } \\
\text { первой }\end{array}$ \\
\hline 1 & 5 & $30,103 \%$ & 5 & $30,10 \%$ \\
\hline 2 & 1 & $17,609 \%$ & 6 & $47,712 \%$ \\
\hline 3 & 2 & $12,494 \%$ & 8 & $60,206 \%$ \\
\hline 4 & 1 & $9,691 \%$ & 9 & $69,897 \%$ \\
\hline 5 & 4 & $7,918 \%$ & 13 & $77,815 \%$ \\
\hline 6 & 1 & $6,695 \%$ & 14 & $84,510 \%$ \\
\hline 7 & 0 & $5,799 \%$ & 14 & $90,309 \%$ \\
\hline 8 & 1 & $5,115 \%$ & 15 & $95,424 \%$ \\
\hline \multirow[t]{2}{*}{9} & 0 & $4,576 \%$ & 15 & $100,000 \%$ \\
\hline & 15 & $100,000 \%$ & & \\
\hline
\end{tabular}


Таблица 8. Динамика латинских слогов у Плавта по Ципфу

\begin{tabular}{|c|c|c|c|c|}
\hline $\begin{array}{l}\text { Динамика } \\
\text { латинских } \\
\text { слогов у } \\
\text { Плавта по } \\
\text { Ципфу, } \\
\text { Первая } \\
\text { цифра }\end{array}$ & $\begin{array}{c}\text { Динамика. } \\
\text { чисел }\end{array}$ & $\begin{array}{l}\text { Значение } F(n) \text { или } \\
\text { вероятность } \\
\text { встретить цифру } \\
\text { первой }\end{array}$ & $\begin{array}{c}\text { Кумулятивные } \\
\text { числа }\end{array}$ & $\begin{array}{c}\text { Значение } F(n) \\
\text { или вероятность } \\
\text { встретить цифру } \\
\text { первой }\end{array}$ \\
\hline 1 & 18 & $30,103 \%$ & 18 & $30,10 \%$ \\
\hline 2 & 8 & $17,609 \%$ & 26 & $47,712 \%$ \\
\hline 3 & 8 & $12,494 \%$ & 34 & $60,206 \%$ \\
\hline 4 & 9 & $9,691 \%$ & 43 & $69,897 \%$ \\
\hline 5 & 3 & $7,918 \%$ & 46 & $77,815 \%$ \\
\hline 6 & 2 & $6,695 \%$ & 48 & $84,510 \%$ \\
\hline 7 & 3 & $5,799 \%$ & 51 & $90,309 \%$ \\
\hline 8 & 4 & $5,115 \%$ & 55 & $95,424 \%$ \\
\hline 9 & 2 & $4,576 \%$ & 57 & $100,000 \%$ \\
\hline & & $100,000 \%$ & & \\
\hline
\end{tabular}

Числа в исследованных произведениях изменяются от 9 (Потоки научнотехнической информации) до 97 (Динамика патентов и рефератов в Chemical Abstracts (1907-2003).

Значение $F(n)$, или вероятность встретить цифру первой во всех примерах составляют при числах $1-9$ от $30,103 \%$ до 4,576\%, а кумулятивные числа - от $30,103 \%$ до $100,000 \%$.

Таким образом, закон Бенфорда применим к информатике (Information Sciences), т.e. подтверждается выдвинутая нами гипотеза и описана простыми алгебраическими уравнениями.

\section{Моделирование простыми алгебраическими уравнениями из информатики.}

Перейдем к моделированию простыми алгебраическими уравнениями перечисленных примеров по информатике (рис. 4-12). 


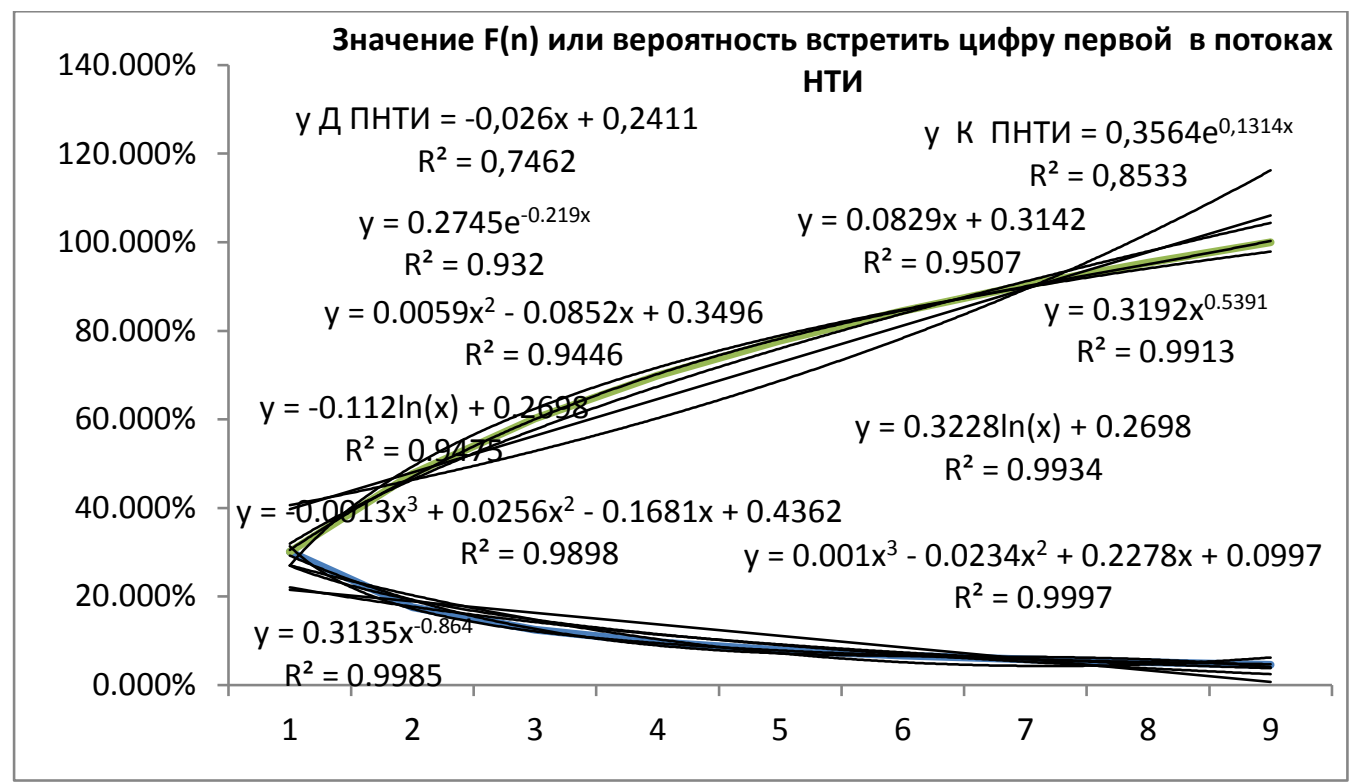

Рис.4. Значение $F(n)$ или вероятность встретить цифру первой в потоках НТИ

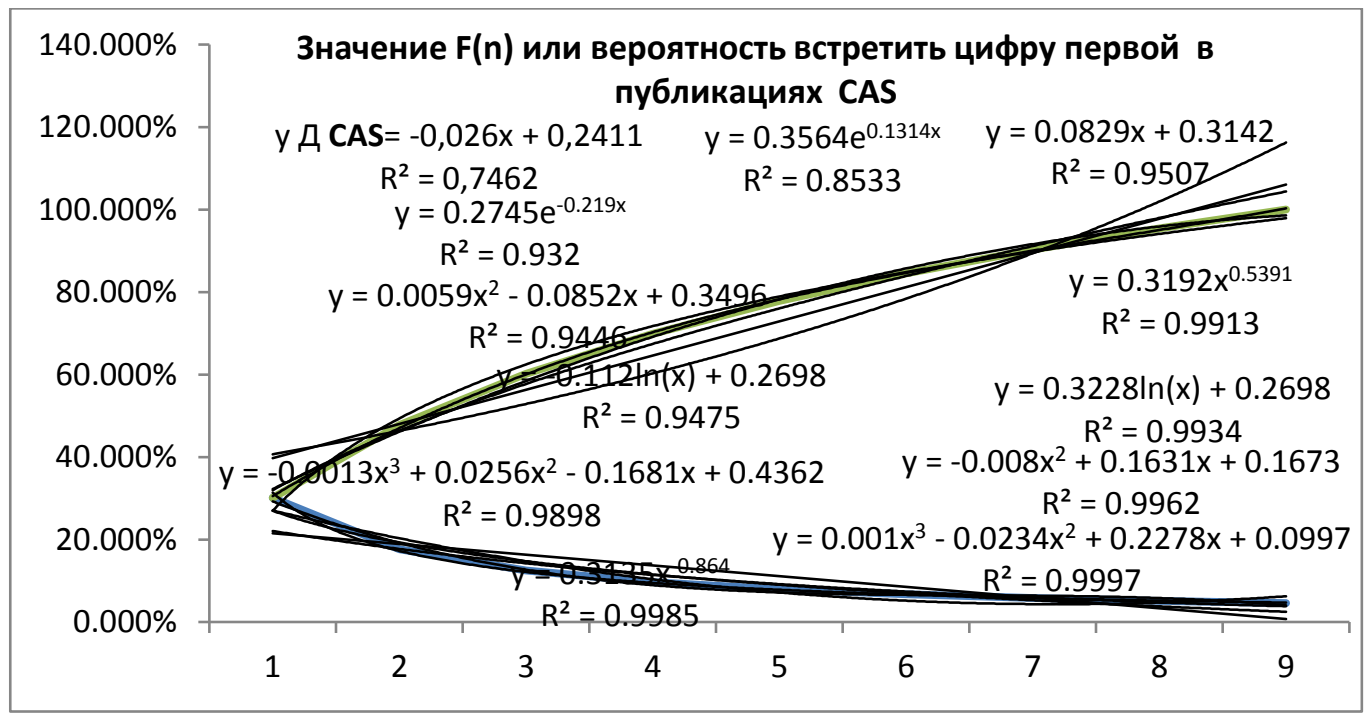

Рис.5. Значение $F(n)$ или вероятность встретить цифру первой в публикациях CA 


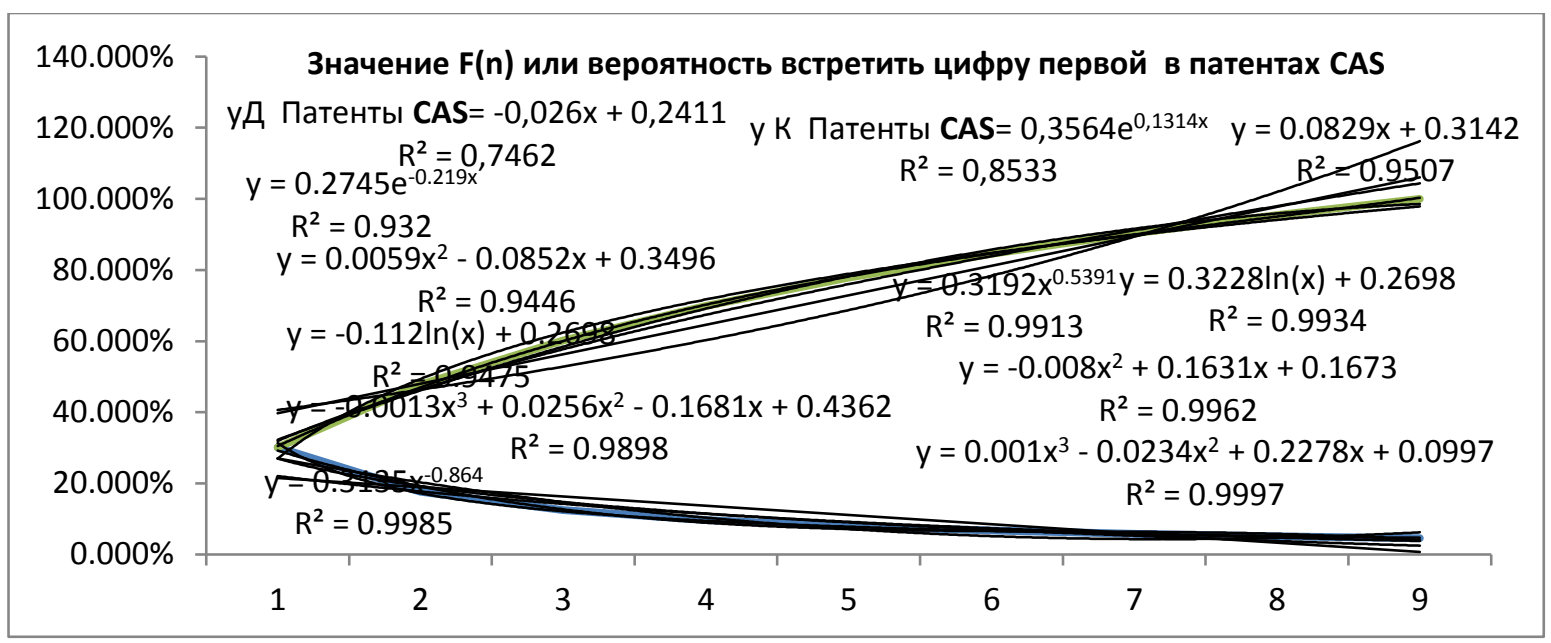

Рис.6 Значение $F(n)$ или вероятность встретить цифру первой в патентах CAS

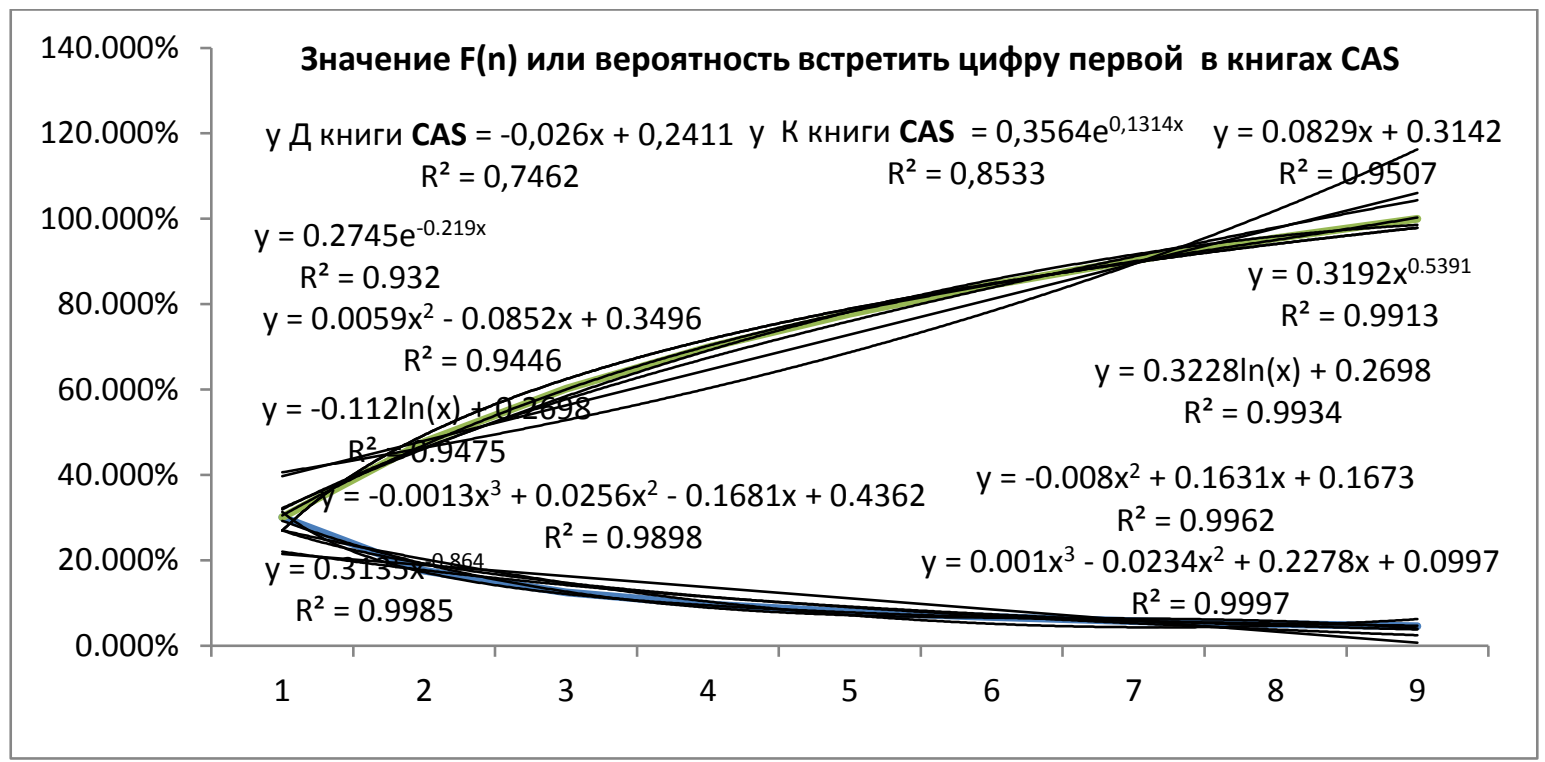

Рис.7. Значение $F(n)$ или вероятность встретить цифру первой в книгах CAS 


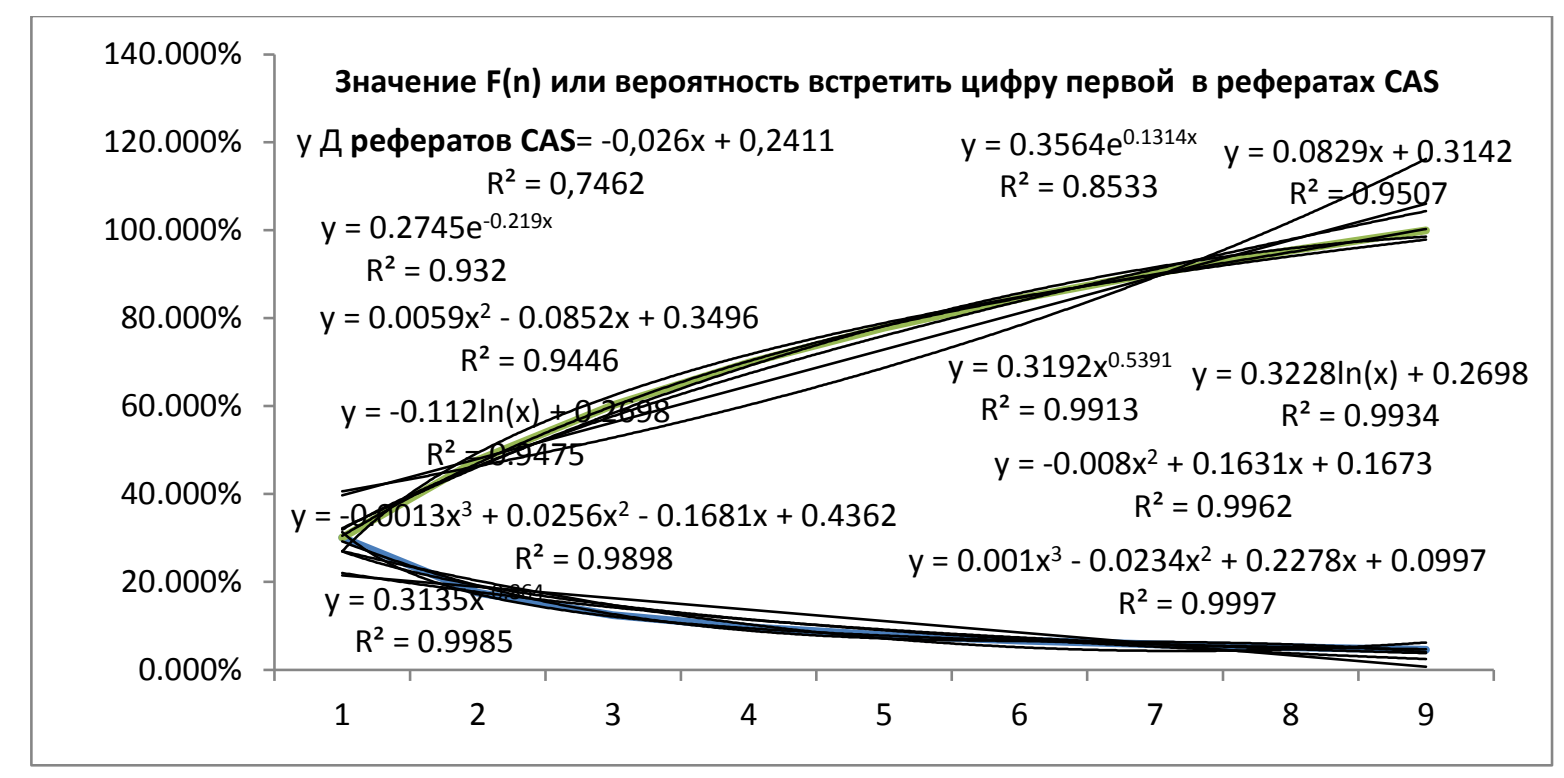

Рис.8. Значение $F(n)$ или вероятность встретить цифру первой в рефератах CAS

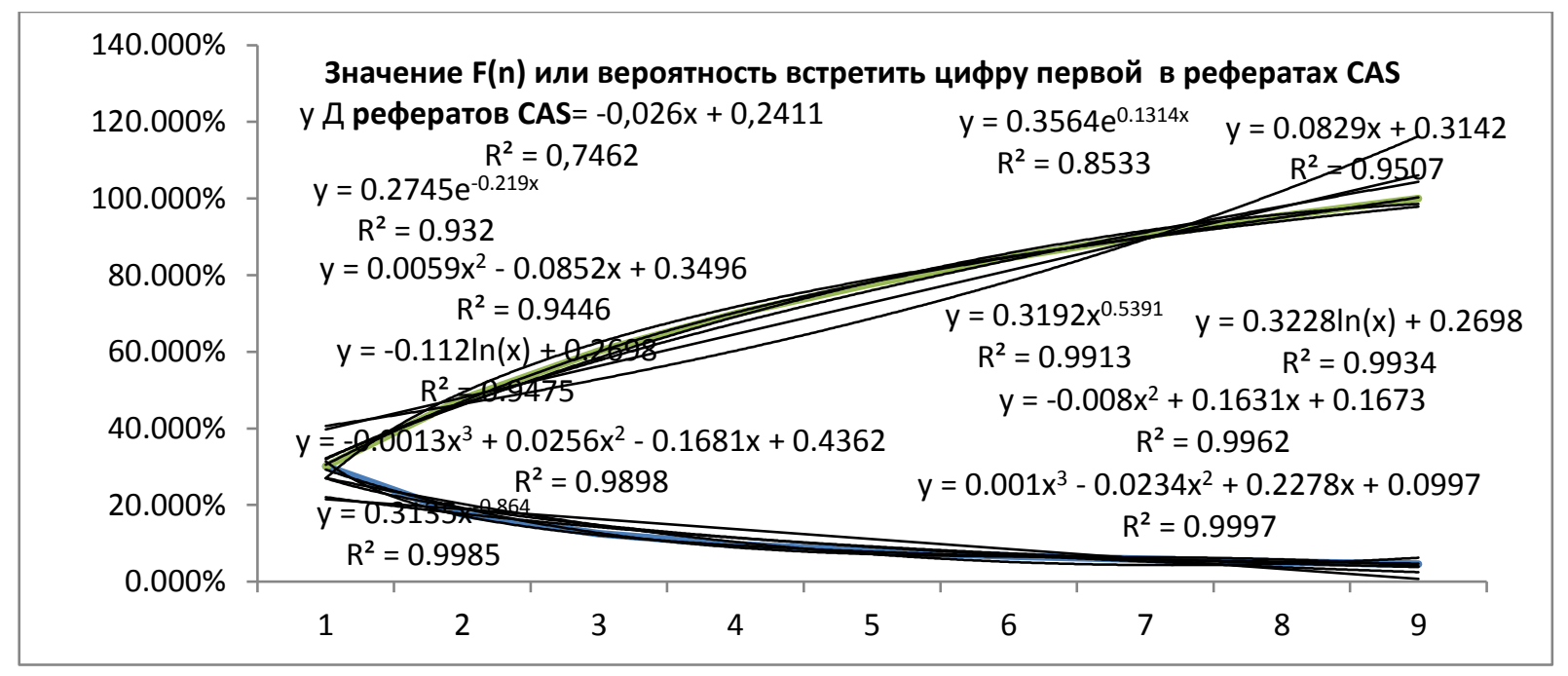

Рис. 9. Значение $F(n)$ или вероятность встретить цифру первой в рефератах CAS 


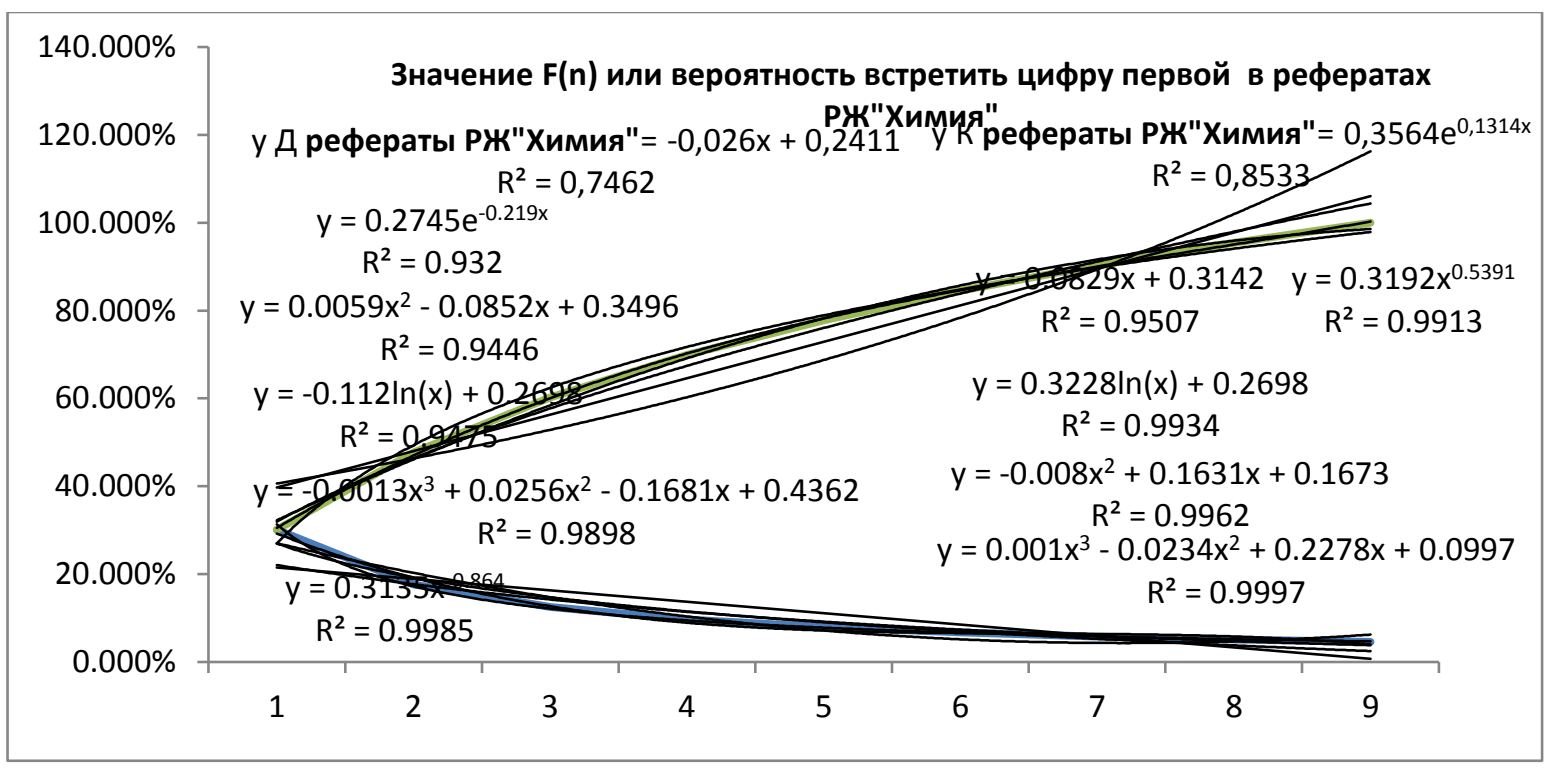

Рис.10. Значение $F(n)$ или вероятность встретить цифру первой в рефератах РЖ «Химия" ВИНИТИ ПАН

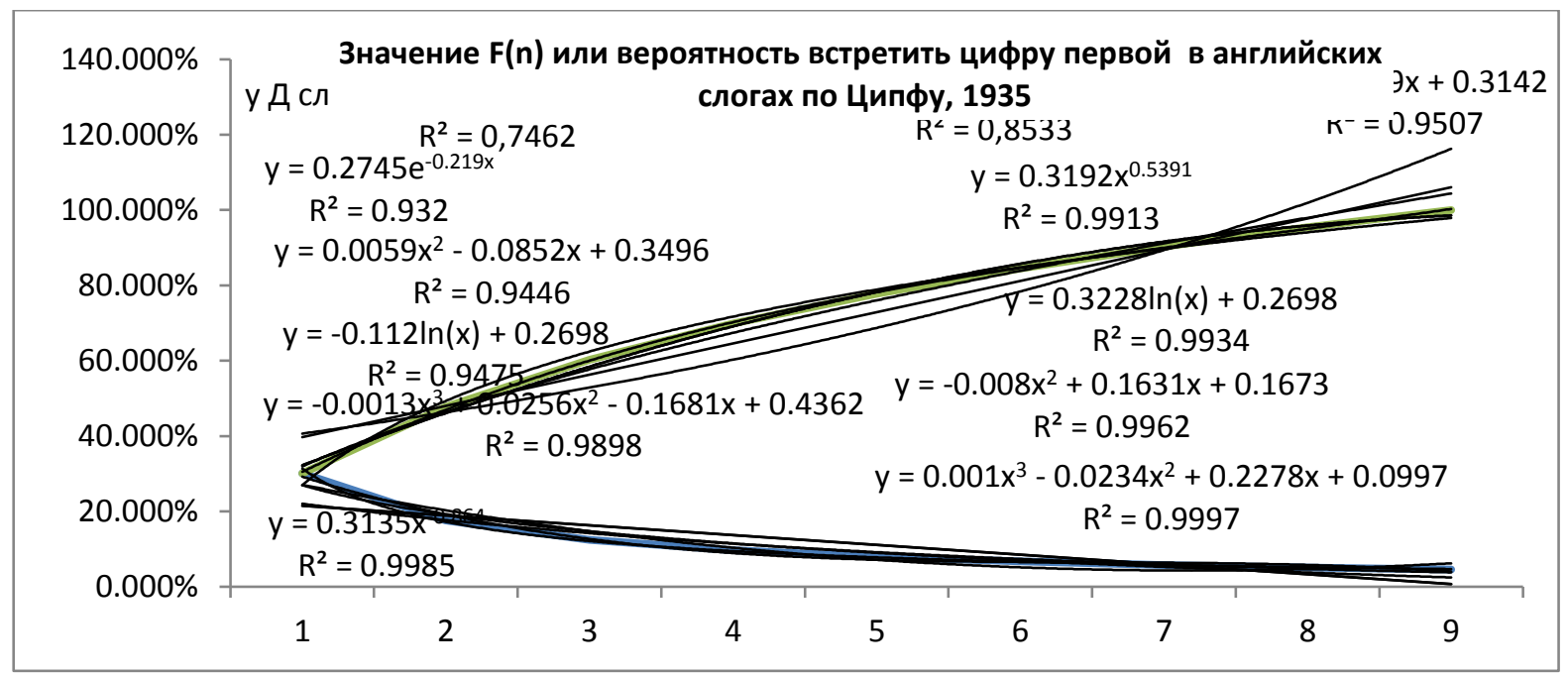

Рис.11. Значение $\mathrm{F}(\mathrm{n})$ или вероятность встретить цифру первой в английских слогах по Ципфу [6] 


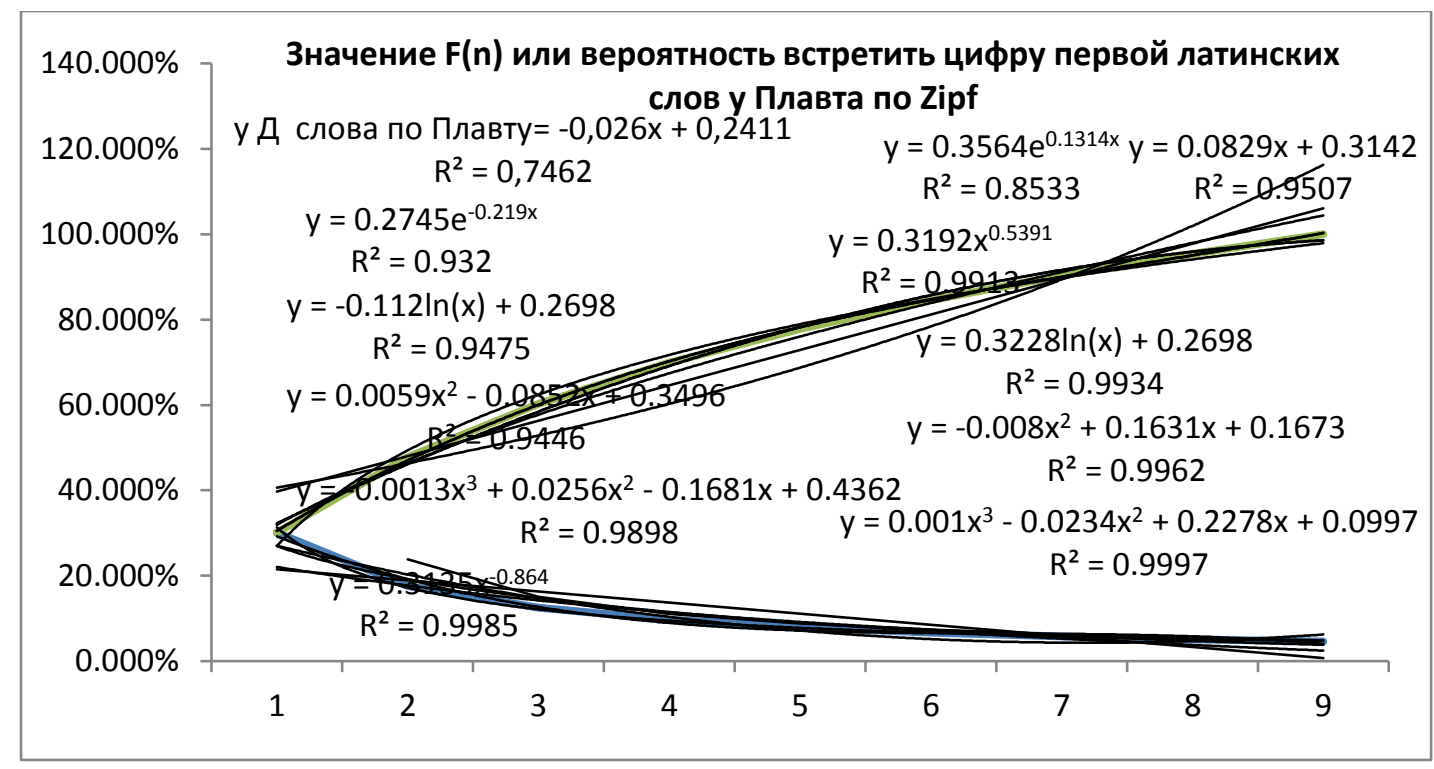

Рис.12. Динамика латинских слогов у Плавта по Ципфу [6]

Представленные простые алгебраические уравнения для всех примеров на рис. 412 динамики значений $F(n)$ имеют одинаковые значения, например, у дпнти $=-0,026 \mathrm{x}$ $+0,2411, \mathrm{R}^{2}=0,7462 ; \mathrm{y}=0,2745 \mathrm{e}^{-0,219 \mathrm{x}}, \mathrm{R}^{2}=0,932, \mathrm{y}=0,0059 \mathrm{x}^{2}-0,0852 \mathrm{x}+0,3496, \mathrm{R}^{2}=$ $0,9446, y=-0,112 \ln (x)+0,2698, R^{2}=0,9475, y=-0,0013 x^{3}+0,0256 x^{2}-0,1681 x+0,4362$, $\mathrm{R}^{2}=0,9898, \mathrm{y}=0,3135 \mathrm{x}^{-0,864}, \mathrm{R}^{2}=0,9985$ описывается с достаточной тояностью экспоненциальным уравнением полиномом второй степени, логарифмическимм уравнением, полиномом третьнй степени и степенным уравнением, а значения $F(n$ для кумуляты ПНТИ; у қ пнти $=0,3564 \mathrm{e}^{0,1314 \mathrm{x}}, \mathrm{R}^{2}=0,8533 ; \mathrm{y}=0,0829 \mathrm{x}+0,3142, \mathrm{R}^{2}=0,9507$; $\mathrm{y}=0,3192 \mathrm{x}^{0,5391,}, \mathrm{R}^{2}=0,991 ; \mathrm{y}=0,3228 \ln (\mathrm{x})+0,2698, \mathrm{R}^{2}=0,9934 ; \mathrm{y}=0,001 \mathrm{x}^{3}-0,0234 \mathrm{x}^{2}$ $+0,2278 \mathrm{x}+0,0997, \mathrm{R}^{2}=0,9997$ описывается с достаточной тосномтью линейным, степенным т лошгарифмическим уравнениями и полиномом третьей степени.,

Следует отметить, что $F(n)$ или вероятность встретить цифру первой по простым алгебраическим уравнениям имеют различные значения: для динамики $0,2745=27,45 \%$ и для кумуляты 0,3564=35,64\% (экспоненциальное уравнение), для динамики 0,3135=31,35\% и для кумуляты 0,3192=31,92 (степенное уравнение) и для динамики $0,2411=24,11 \%$ и для кумуляты 0,3142=31,42 (линейное уравнение)

Таким образом, моделирование $F(n)$ или вероятность встретить цифру первой по простым алгебраическим уравнениям подтверждает значения 30,108\% по днамике и $0,3135=31,35 \%$ и по кумуляте $0,3192=31,92 \%$ (степенное уравнение) и по кумуляте $0,3142=31,42 \%$ (линейное уравнение) и описываются с наибольшей точностью от экспоненциального уравнения до полинома третьей степени. Наилучшей моделью является полином третьей степени. 


\section{Выводы}

1 Впервые закон Бенфорда подтверждается для информатики и уточняется простыми алгебраическими уравнениями для динамики и кумулятивного числа цифр.

2 Впервые также показано по простым алгебраическим уравнениям различие динамики и кумуляты для относительной и относительной экспоненциальной скоростей изменения $F(n)$ или вероятности встретить цифру первой.

3 Закон Бенфорда по лексикологии сближается с исследованными нами квантитативными характеристиками в области информатики и другими областями знания о Вселенной, т.е. является всемирным ·

\section{References}

1. Baguzin. Zakon Benforda ili zakon pervoj cifry [Benford law or first digit law] http://baguzin.ru/wp/zakon-benforda-ili-zakon-pervoj-tsifry/

2. Mlodinov L. (Ne) sovershennaja sluchajnost'. Kak sluchaj upravljaet nashej zhizn'ju [(Not) perfect coincidence. How chance controls our lives].

URL: http://baguzin.ru/wp/leonard-mlodinov-nesovershennaya-sluch/

3. Schetnikov A. I.. Shchetnikova A. V. Teaching and Researching Seminar "Distribution of the First Significant Digits" Math. Ed., 2002, Issue 2(21), Pages 108-123 (Mi mo525)

4. Ritera - kāto |Roshia shoseki senmon mise Nauka Japan [Litera - Cart | Russian book specialty shop Nauka · Japan] URL: naukajapan.jp/detail.php?id=153315\&PHPID.

5. Klimov Ju.N. Kvantitativnaja leksikologija, korpusnaja lingvistika i kolichestvennaja informatika: monografija. [Quantitative lexicology, corpus linguistics and quantitative informatics: monograph], Moscow, OchU VO "MMA", 340 p., hard. 2016. ISBN 9785904360542 R153315

6. Zipf G. K. Human behavior and the principle of least effort. «Addison-Wesley Publishing» Cambridge, 1949. 
DOI 10.32370/2018_09_4

\title{
Children's Literature Tracks in Disney Films and Azerbaijani Children's Auditorium
}

\author{
Abdullayeva Turana Madar \\ Baku Engineering University
}

\begin{abstract}
As we know, Walt Disney, a filmmaking organization in the 20th century, has produced films that have been loved not only in his homeland, but also far from his homeland. Among these films, films produced for children have attracted more attention, and the young American children's literature, has begun to bring its effect to a small audience. The close relationship between Disney films and children literature has had an indispensable impact on the development of American children's literature. The animated films that they watched make children the desire to read literature. The parents, who have come to appreciate all of this, have drawn them to education. Walt Disney films are among the famous animated films not only in America, but also in many countries all over the world.
\end{abstract}

Keywords: cartoon, Disney film, animation, innovator

Walt Disney was born on 5 December 1901 in Chicago in a very poor family who came originally from Irish, English and German. He has been working as a cartoon artist in Kansas City since 1919. Later, he joined the Disney advertising campaign and started working with Ub Iwerks. Together they made Disney's famous heroes, drawing cartoons and creating a film called "The Laugh of Laughter." In this form, the first commercials started functioning. After that, Walt Disney created his own "Laugh O Gram", a very small personality. Like Walt Disney, almost no one has been rich in fantasy. The talented artist worked as an ambulance driver during the First World War. He died of lung cancer in 1966 [2].

In 1921, after World War I, Walt Disney returned to Kansas and started a business relationship with the animator Ub Iwerks. Walt Disney has created great talent "Red Hat", "Cat in Boots" and others. The two-part animated film "Alisa in the Land of Wonders" created an animated film. In addition, a new film, "Osvald - Happy Rabbit" was released by the company during this period. The new personality, Mickey Mouse, appeared in Disney's film which is called "Wrecked Aircraft. The new personality's name was given by Walt's wife, Lillian. Mickey Mouse was awarded the Disney "Oscar" award in 1932 for the creation of her personality. In 1939, Leon Schlesinger noted about Mickey Mouse at "Look"- "Today's animation is a great fun for young and old people, but first of all, it's fun for kids. That's why we always have to make the products fit into children's thinking" [6]. At the beginning of the 
1930s, Disney's painting techniques developed, and it had a strong impact on the psychology of the Americans. Especially children's characters created on animals became more and more objects of interest.

Ub Iwerks has had an invaluable role in the emergence of the original Disney heroes. Starting in the 1930s, Walt Disney has already had a strong status in the animation field. The company was very sensitive to this work because it takes its products for children [4]. As you can see, many of these characters were created on the basis of heroes of folk tales. The company understood very well that these tales were favorite of all children, and the animation of these subjects would lead to more children watching. Disney's film cartoon was "Snow White and the Seven Dwarfs" which film based on the German fairy tale by the Brothers Grimm, it is the first full-length animated feature film and the earliest Disney animated feature film. Disney films have appealed not only to American children's literature, but also to many oral and written children's literature in the world. Therefore Disney children's films were quite diverse.

In 1933, Disney producued the first colorful cartoon in the world. This animated film, "Three Little Pigs", was based on the motifs of English tales and Disney was awarded Oscar for the second time.

The 40's of the 20th century, it is a sensitive period in world literature like world history. Changes in society have affected one form of literature and culture. Among the middleclass Americans, the Great Depression, which started before the Second World War, continued during the war. At this period, parents' fears and feelings of insecurity have not been neglected by the children's upbringing and relationships with the community. Literary critics have tried to be careful when describing this period. For example, C. Anderson Aldrich and Mary Aldrich argued that children forced to adhere to the strict regimes of management-oriented childrearing were likely to grow into adults who were unspontaneous, efficient, and cold: "Anyone who has watched a mechanical robot perform his incredible acts of skill, has probably been conscious not only of wonder but also of a certain obscure impression of fear. The spectacle of someone acting correctly without feeling anything is so inhuman that it is vaguely unpleasant" [1].

In 1941, film-maker was paying close attention to the new this Dumbo. This film was a start to finding of children's literature among children's films. Particularly, the film focuses on issues such as the upbringing of children, the elimination of contemporary concerns about 
the proper upbringing of children, the regulation of social and cultural relations. The film "Dumbo" can be understood as part of children's literature. Here are some basic reasons to think so. First, it appears that from the day Disney was created, films are seen as potential competitors in the middle class and demonstrate selective literature on children's education and upbringing. Secondly, Hollywood has long worked for children in the context of the combination of films. When Disney started producing long-term cartoons in the late 1930s, these films included not only smaller essays like Collodi, but also from children's literature covering the classic works of the eighteenth and nineteenth centuries, from Perult and Grimm [8].

In fact, Disney films (and books, dresses and toys) were a school to create a message expressing parents' democratic desires for success in capitalist society in a centuries-old history. At the end of the 19th century, since the opening of the modern film industry, there was a sense of fear about the impact of the film on the child's developing mind, so censorship and argumentation on films appeared [3]. Therefore, state control over the newly created film industry was strong, the content of movies with melodrama, crime, and open romance scenes that had been found to be inappropriate for adults, was allegedly caused by "early premature growth" of children., these types of films could have a negative impact on their psychological status and upbringing, taking into account all of this, the company has professionally chosen the themes and heroes of the films it creates.

Overall, Disney films which were produced from the 1930's till today, have once again proved its relevance to children's literature. "Snow White", 1937, "Pinocchio", 1940, "Dumbo" 1941, "Bambi", 1942, "Song of the South", 1946, "Wind in the Willows", 1949, "Cinderella", 1950, "Alisa in Wonderland", 1951, "Peter Pen", 1953 and "Sleeping Beauty", 1959, “The Jungle Book”, 1967, “The Wild Country”,1970, “The Million Dollar Duck”, 1971, "Robin Hood" 1973, “The Many Adventures of Winnie the Pooh", 1977, "The Little Mermaid”, 1989,“All Dogs Go To Heaven”, 1989, “Lion King”, 1994 and so on are among the films that are in the hearts of children. These animated films, based on the integration of classic folk tales and works, were not only distracted by the children, but also their adults.

Walt Disney has not been left out of politics among the views expressed in his films. With a number of films, he delivers some skillful political views [9]. As an example, let's look at the film "Jungle book". "The Jungle Book" is actually reflected in the colonial policy of 
Britain in India. Even though I would say that the company wanted to show Mowgli as a Briton, and the animals what helped Mowgli as Indians. At the end of film Mowgli abandoned animals and the place where he grew up, resembled British politics after colonialism.

Like many other countries in the world, in the Republic of Azerbaijan children are also fond of Walt Disney movies. The best examples of foreign literature were studied on the basis of these films by Azerbaijani children's audiences. These films play an indispensable role in the development of children as individuals in society.

Overall, today Walt Disney is the world's number one for Oscar winner. He has won 26 Oscar in total. It is once again proved that makes the Disney films and children's literature closer to each other. All of this, in turn, affects the development of American children's literature in a positive sphere in most countries of the world.

\section{References}

1. Aldrich, C. Anderson, and Mary M. Aldrich. Babies Are Human Beings: An Interpretation of Growth. New York: Macmillan, 1938

2. Barrier, Michael. The Animated Man: The Life of Walt Disney. Berkeley: U of California P, 2007

3. Couvares, Francis G., ed. Movie Censorship and American Culture. Washington: Smithsonian Institution Press, 1996

4. Gould, Stephen Jay. The Panda's Thumb: More Reflections in Natural History. New York: Norton, 1980

5. Mitman, Gregg. Reel Nature: America's Romance with Wildlife on Film. Cambridge, MA: Harvard UP, 1993

6. Sampson, Henry. That's Enough, Folks: Cartoon Images in Animated Cartoons, 1900- 1960. London: Scarecrow Press, 1998

7. Sammond, Nicholas. Babes in Tomorrowland: Walt Disney and the Making of the American Child, 1930-1960. Durham: Duke UP, 2005

8. For a discussion of the place of the fairy tale in mass culture, see Zipes. For a discussion of Disney's marketing to children, see deCordova 1983 and 1994

9. https://www.indy100.com/article/10-political-messages-you-didnt-realise-werehidden-in-disney-movies--b17htesM9bb 
Translation of the Title, Abstract and References to the Author's Language

\title{
Следы детской литературы в фильмах Диснея и азербайджанская детская аудитория \\ Абдуллаева Турана Мадар \\ Бакинский инженерный университет
}

\begin{abstract}
Аннотация
Как мы знаем, Уолт Дисней, кинорежиссёрская организация в 20 веке, выпустила фильмы, которые были любимы не только на его родине, но и далеко от его родины. Среди этих фильмов фильмы, созданные для детей, привлекли больше внимания, а молодая американская детская литература начала приносить свой эффект небольшой аудитории. Тесная связь между фильмами Диснея и детской литературой оказала незаменимое влияние на развитие американской детской литературы. Анимированные фильмы, которые они смотрели, воодушевляли детей читать литературу. Родители, которые оценили всё это, привлекли их к образованию. Фильмы Уолта Диснея относятся к числу известных анимационных фильмов не только в Америке, но и во многих странах мира.
\end{abstract}

Ключевые слова: мультфильм, Дисней фильм, анимация, новатор 


\title{
Pedagogical Conditions of the Formation of Value Attitude to Another Person in Teenagers of Comprehensive Boarding Schools
}

\author{
Filonenko Lesia \\ ORCID: https://orcid.org/0000-0002-1969-8387 \\ Postgraduate student \\ Vinnytsia Mykhailo Kotsubynskyi State Pedagogical University (Ukraine)
}

\begin{abstract}
This article gives a theoretically substantiated pedagogical conditions of the formation of a value attitude to another person in teenagers of boarding schools such as: the development and the implementation of the content, forms and methods of the formation of a value attitude to another person in teenagers of boarding schools; the involvement of teenagers of boarding schools to humane-oriented activities; the humanisation of relations within the system «pedagogue-student», «student-student»; the enhancement of the level of the readiness of teachers of boarding schools to the formation of a value attitude to another person in teenagers. The formation of a value attitude to another person in teenagers of boarding schools includes: the expansion of boarding schools teenagers' ethic knowledge about the respect to dignity, benevolence, equal rights, self-sufficiency, reasonableness; the formation of positive motivation among teenagers of boarding schools; skills of self-readiness and the readiness to a constructive dialogue. The development and the implementation of the content, forms and methods of the formation of a value attitude to another person was done in various ways such as: conducting educative hours, philosophical classes, movie discussions, the discussion of stories and books, a training, individual consultations, quizzes, talks, drawings exhibitions.

Methods: stories, explanations, ethic talks, pedagogical demand, a public opinion, exercises, models, duties, discussions, role, imitation games, narratives, the creation of educative situations. The involvement of teenagers of boarding schools to the humane-oriented activity aiming at the formation of a value attitude to another person was done by means of student self-governance. We used such forms as campaigns, events, concerts, team work for the sake of others, a project work, etc. The process of the humanisation of relations in the system «pedagogue-student», «student-student» embraced the following: the humanisation of relations among pedagogical faculty of a boarding school; the humanisation of an educational process; the humanisation of relations between teenagers of boarding schools.

The enhancement of the degree of the readiness of teachers of boarding schools to the formation of a value attitude to another person in teenagers was done while conducting the seminar «We are forming a value attitude to another person in teenagers of boarding schools» (lectures, interactive classes).

Keywords: teenagers, pedagogical conditions, the formation of a value attitude to another person, educators, a comprehensive boarding school.
\end{abstract}

Актуальність дослідження. У зв'язку з глибинними перетвореннями в соціальноекономічному та культурному житті українського суспільства, особливої гостроти набуває проблема морального виховання молодого покоління, а відтак і формування ціннісного ставлення до іншої людини.

Проблема формування ціннісного ставлення до іншої людини у молодого 
покоління розглядається в різних аспектах: гуманістичний підхід (К. Журба, В. Киричок, К. Чорна); особливості взаємодії з іншими людьми (А. Амонашвілі, І. Бех, І. Білецька, В. Білоусова, I. Бужина, О. Докукіна, Л. Канішевська, Г. Кирмач, О. Коберник, О. Третяк, Н. Щуркова та ін.).

Однак поза увагою науковців залишився такий аспект, як формування цүіннісного ставлення до іншої людини у підлітків шкіл-інтернатів, що стало метою нашої статті.

Виклад основного матеріалу. Найважливішими завданнями шкіл-інтернатів є: створення умов, які б забезпечували їм участь у всіх сферах соціальних відносин; формування соціальних умінь; допомога в особистісному та професійному самовизначенні; підготовка вихованців до самостійного життя [2, с. 293; 6; 7; 8; 11$]$.

Аналіз психолого-педагогічної літератури, визначення стану сформованості ціннісного ставлення до іншої людини у підлітків шкіл-інтернатів дозволяє визначити педагогічні умови, які підвищують ефективність формування ціннісного ставлення до іншої людини у вищеназваного контингенту учнів та забезпечують їх реалізацію в найтіснішому взаємозв'язку.

Однією з педагогічних умов формування ціннісного ставлення до іншої людини є розроблення та впровадження змісту, форм і методів формування ціннісного ставлення до іншої людини у підлітків шкіл-інтернатів. Зміст формування ціннісного ставлення до іншої людини в підлітків шкіл-інтернатів включав: розширення етичних знань підлітків шкіл-інтернатів про повагу гідності, доброзичливість, рівноправ'я, виваженість, самодостатність; формування у підлітків шкіл-інтернатів позитивної мотивації; формування у підлітків шкіл-інтернатів навичок самопізнання та готовності до конструктивного діалогу.

Серед вербальних методів широко використовувалися етичні бесіди. Особливістю етичних бесід була їхня діалогічність, що давало змогу висловити власну думку усім учасникам. Етична бесіда також будувалася на зворотньому зв'язку та рефлексії, як показниках іï ефективності. Під час проведення етичної бесіди враховувалися моральні запити та потреби підлітків шкіл-інтернатів, проблеми, які вони намагаються вирішити, а також ті, що їх цікавлять, вікові особливості вихованців, гендерний склад. Важливо було, аби етична бесіда орієнтувала школярів на моральні цінності, спонукала до прояву ціннісного ставлення до іншої людини у реальній 
поведінці. Педагоги зважали на те, щоб тема етичної бесіди не лише була актуальною і цікавою для школярів, а й була пов'язана з життям, подіями шкільного життя, життєвим досвідом вихованців. При проведенні етичних бесід зверталася увага на логічне розкриття теми та іï практичне значення для кожного. Практика підтвердила ефективність використання елементів сократівської бесіди у 5-7-х класах та сократівської бесіди у 8-9-х класах. Застосування сократівської бесіди передбачало серію чітко сформульованих запитань, на які підлітки самостійно доходили до правильних висновків щодо необхідності проявів ціннісного ставлення до іншої людини. Так, з підлітками шкіл-інтернатів було проведено бесіди: «Як виявляти повагу до інших?», «Чи вміємо ми дружити?», «Коли піклуються про нас, коли піклуємося ми ?» (5 клас), «Вчимося виявляти співчуття і радість за інших», «Коли потрібна наша допомога?», «Будемо гуманістами» (6 клас), «Доброта зігріє світ», «Не будь байдужим», «Живемо серед людей» (7 клас), «Культура гідності сучасної молодої людини», «Спілкування і стосунки з однокласниками» (8 клас), «Ми творимо своє життя самі» (9 клас).

Свою ефективність довів також метод дискусії, який сприяв формуванню ціннісного ставлення до іншої людини у підлітків шкіл-інтернатів через виховання культури дискусії, навичок опонування, доведення своєї позиції, добір аргументів. Зокрема, з підлітками шкіл-інтернатів було проведено дискусії за наступними темами: «Бути собою чи бути як усі?», «Білі ворони» в колективі», «Хочу! Можу! Треба! Чи можливо їх узгоджувати?», «Доброта і егоїзм», «Якою має бути дружба?».

Наступною педагогічною умовою $є$ залучення підітків шкіл-інтернатів до гуманістично спрямованої діяльності з формування ціннісного ставлення до іншої людини.

Пристаємо до думки Канішевської, яка зазначає, що не кожна діяльність може бути визначена як сфера виховання. «Такими можуть вважатися лише ті їі різновиди, в яких діяльність дитини спрямовується на пізнання і перетворення навколишнього світу і самої себе, відбувається виховна взаємодія, і, як наслідок, вона оволодіває тими чи іншими елементами соціального досвіду, людської культури» [4, с. 95]. Соціальна діяльність може бути непомітною, але вона все одно залишається соціально значущою. 
Ця діяльність може здійснюватись один на один з книгою, у мріях, у розмовах і зізнаннях [3, c. 117].

У процесі дослідно-експериментальної роботи було використано такі види діяльності, спрямовані на виявлення ціннісного ставлення до іншої людини: навчальна допомога слабким учням (під час самопідготовки), залучення підлітків шкіл-інтернатів до суспільно значущих справ, а саме: допомога хворим, літнім людям, пенсіонерамодинакам, колективна праця для інших людей, участь у заходах до Дня захисту дітей, Дня інвалідів, Дня людей похилого віку; виготовлення привітань зі святами для учителівпенсіонерів, ветеранів; підготовка святкового концерту та виготовлення подарунків для молодших школярів, подарунки солдатам тощо.

Наступна педагогічна умова формування ціннісного ставлення до іншої людини у підлітків шкіл-інтернатів - гуманізащія взаємин у системі «педагог-учень», «ученьучень».

Нами було виокремлено наступні напрями гуманізації взаємин у системі «педагог-учень», «учень-учень»: гуманізація відносин у педагогічному колективі школи-інтернату, що полягала в гуманізації управління з боку керівництва закладу освіти; формування доброзичливої громадської думки; розвитку толерантних взаємин між педагогами; створення сприятливого психологічного клімату у школі-інтернаті; гуманізація освітнього процесу, яка полягала в індивідуалізації та диференціації навчання; співпраці педагогів та учнів у вирішенні питань організації життєдіяльності вихованців; залучення підлітків шкіл-інтернатів до гуманістично спрямованої діяльності; гуманізація взаємин між підлітками шкіл-інтернатів, що передбачає створення в школі-інтернаті атмосфери гуманності, взаєморозуміння; формування в особистості орієнтації на іншу людину, розуміння іiї почуттів, виявлення співчуття до іншої людини; уміння ставити інтереси іншої людини вище за свої; формування в учня здатності чинити опір власним негативним якостям.

Здійснюючи педагогічну підтримку, педагоги стимулювали у вихованців самопізнання своїх позитивних рис; формували моральні якості школяра у процесі оцінювання власної поведінки; акцентували увагу на позитивних вчинках учнів; підтримували ініціативу, активність [1, с. 219]. 
Підвищення рівня готовності вихователів шкіл-інтернатів до формування ціннісного ставлення до іншої людини у підлітків відбулося під час проведення семінару «Формуємо ціннісне ставлення до іншої людини у підлітків шкіл-інтернатів» (лекції, інтерактивні заняття).

Висновки. Одержані результати засвідчили істотне зростання кількості підлітків шкіл-інтернатів із високим і середнім рівнями сформованості ціннісного ставлення до іншої людини в експериментальній групі порівняно 3 контрольною. Динаміка рівнів сформованості ціннісного ставлення до іншої людини у підлітків шкілінтернатів для високого рівня - +11,39 \%; середнього - + 21,95\%; низького - -33,34 \% .

Через що, проведене дослідження не вичерпує багатогранності теоретичних i практичних пошуків розв'язання проблеми. Подальшого вивчення i розвитку потребують такі питання, як то питання формування ціннісного ставлення до іншої людини в учнів шкіл-інтернатів інших вікових груп (молодші школярі, старшокласники).

\section{References}

1. Kanishevska L. V. Doslidzhennia problemy vykhovannia sotsialnoi zrilosti starshoklasnykiv shkil-internativ. [The research of the problem of fostering social maturity in senior students of orphan boarding schools]. Pedahohichnyi almanakh: zb. nauk. prats. Kherson KVNZ "Khersonska akademiia neperervnoi osvity", 2012. Issue 16. P. 213-220.

2. Kanishevska L.V. Doslidzhennia problemy pidhotovky starshoklasnykiv shkilinternativ do samostiinoho zhyttia. [The research of the problem of preparing senior students of orphan boarding schools to their own life] // Teoretyko-metodychni problemy vykhovannia ditei ta uchnivskoi molodi: zb. nauk. prats. Kirovohrad: Imeks - LTD, 2013. Issue 17, Kn. 1. P. 293-299.

3. Kanishevska L. V. Orhanizatsiia sotsialno-kulturnoi diialnosti starshoklasnykiv z formuvannia sotsialnoho dosvidu. [The organisation of social and cultural activities for senior students in order to form their social experience] // Teoretyko-metodychni problemy vykhovannia ditei ta uchnivskoi molodi : zb. nauk. prats. Kirovohrad : TOV "Imeks-LTD", 2010. Issue 14. Kn. 1. P. 116-124.

4. Kanishevska L. V. Pidhotovka starshoklasnykiv shkil-internativ do zhyttiediialnosti u vidkrytomu suspilstvi (vykhidni kontseptualni polozhennia). [Preparation of senior pupils of boarding schools for living in an open society (outgoing conceptual provisions)] // Teoretykometodychni problemy vykhovannia ditei ta uchnivskoi molodi : zb. nauk. prats Issue 15 . Kn. 2 Kamianets-Podilskyi: Vydavets PP Zvoleiko D. H., 2011. P. 88-97.

5. Kanishevska L.V. Formuvannia zhyttievoi kompetentnosti pidlitkiv shkil-internativ [Formation of life skills of adolescents of boarding schools]. Novi tekhnolohii navchannia. 2006. No 44. P. 86-91. 
6. Pet'ko L.V. Vykhovnyi potentsial metodu sytuatsiinoho analizu ("Case study» method) u formuvanni profesiino oriientovanoho inshomovnoho navchalnoho seredovyshcha $v$ umovakh universytetu [Educational potential of the «Case study» method for the forming of the professionally oriented foreign language teaching environment in the conditions of university]. Naukovyi chasopys NPU imeni M.D.Drahomanova. Seriia 17. Teoriia i praktyka navchannia ta vykhovannia : zb. nauk. pr. Kyiv: Vyd-vo NPU imeni M.P.Drahomanova, 2015. Issue 27. P. 133-140.

7. Pet'ko L. V. Sotsialno-komunikatyvna aktyvnist pidlitkiv: teoriia $i$ praktyka [Monohrafiia]. [Social and communicative activity of adolescents: theory and practice [Monograph]. Kyiv: VMURoL "Ukraina", 2010. 268 p.

8. Filonenko Lesia. The peculiarities of forming value attitude to another person in teenagers of boarding schools. Intellectual Archive. - Toronto: Shiny World Corp. (Canada). 2018. (July/August). Vol. 7. No. 4. PP. 80-85. https://doi.org/10.32370/2018_07_80

9. Kanishevska L.V., Stadnik N.V. Theoretical aspects of the concept "responsibility" in works by foreign researchers. Perspectives of research and development: Collection of scientific articles. SAUL Publishing Ltd, Dublin, Ireland, 2017. P. 129-131.

10. Pet'ko Lyudmila. The "Case Study" Method as Means of Formation of a Professionally Oriented Foreign Language Teaching Environment in University Conditions. Intellectual Archive. 2015. Volume 4. Num. 4 (July). Series "Education \& Pedagogy". Toronto: Shiny World Corp. PP. 48-65.

11. Shkolna Maria. Pedagogical conditions for upbringing social maturity of students' agricultural colleges. Intellectual Archive. Toronto: Shiny World Corp. (Canada). 2017. September/October. Vol. 6. No. 5. PP. 79-85.

\section{Translation of the Title, Abstract and References to the Author's Language}

\section{УДК: 37.018.32 - 057. 87:17.022.1:316.454-043.83}

Філоненко Леся. Педагогічні умови формування ціннісного ставлення до іншої людини у підлітків загальноосвітніх шкіл-інтернатів.

У статті теоретично обгрунтовано педагогічні умови формування ціннісного ставлення до іншої людини у підлітків шкіл-інтернатів, а саме: розроблення і впровадження змісту, форм і методів формування ціннісного ставлення до іншої людини у підлітків шкіл-інтернатів; залучення підлітків шкіл-інтернатів до гуманістично спрямованої діяльності; гуманізація взаємин у системі «педагог-учень», «учень-учень»; підвищення рівня готовності вихователів шкіл-інтернатів до формування ціннісного ставлення до іншої людини у підлітків. Одержані результати засвідчили істотне зростання кількості підлітків шкіл-інтернатів із високим i середнім рівнями сформованості ціннісного ставлення до іншої людини в експериментальній групі порівняно $з$ контрольною, що свідчить про ефективність апробованих педагогічних умов.

Ключові слова: педагогічні умови, формування ціннісного ставлення до іншої людини, підлітки, вихователі, загальноосвітня школа-інтернат.

\section{Jimepamypa}


1. Канішевська Л. В. Дослідження проблеми виховання соціальної зрілості старшокласників шкіл-інтернатів. Педагогічний альманах : зб. наук. праць. Херсон КВНЗ «Херсонська академія неперервної освіти», 2012. Вип. 16. С. 213-220.

2. Канішевська Л. В. Дослідження проблеми підготовки старшокласників шкілінтернатів до самостійного життя. Теоретико-методичні проблеми виховання дітей та учнівської молоді: зб. наук. праць. Кіровоград: Імекс - ЛТД, 2013. Вип. 17, Кн. 1. C. 293-299.

3. Канішевська Л. В. Організація соціально-культурної діяльності старшокласників 3 формування соціального досвіду. Теоретико-методичні проблеми виховання дітей та учнівської молоді: зб. наук. пр. Кіровоград: ТОВ «Імекс-ЛТД», 2010. Вип. 14. Кн. 1. С. 116-124.

4. Канішевська Л. В. Підготовка старшокласників шкіл-інтернатів до життедіяльності у відкритому суспільстві (вихідні концептуальні положення). Теоретико-методичні проблеми виховання дітей та учнівської молод $i$ : зб. наук. праць Вип. 15. Кн. 2 Кам'янець-Подільський: Видавець ПП Зволейко Д. Г., 2011. С. 88-97.

5. Канішевська Л. В. Формування життєвої компетентності підлітків шкілінтернатів. Нові технологї̈ навчання. 2006. № 44. С. 86-91.

6. Петько Л.В. Виховний потенціал методу ситуаційного аналізу («Сase study» method) у формуванні професійно орієнтованого іншомовного навчального середовища в умовах університету. Науковий часопис НПУ імені М.Д.Драгоманова. Серія 17. Теорія i практика навчання та виховання : зб. наук. пр. ; за ред. академіка В.І.Бондаря. Київ: Вид-во НПУ імені М.П.Драгоманова, 2015. Вип. 27. С. 133-140.

7. Петько Л. В. Соціально-комунікативна активність підлітків: теорія і практика [Монографія]. К. : ВМУРоЛ «Україна». 2010. 268 с.

8. Filonenko Lesia. The peculiarities of forming value attitude to another person in teenagers of boarding schools. Intellectual Archive. - Toronto: Shiny World Corp. (Canada). 2018. (July/August). Vol. 7. No. 4. PP. 80-85. https://doi.org/10.32370/2018_07_80

9. Kanishevska L. V., Stadnik N. V. Theoretical aspects of the concept "responsibility" in works by foreign researchers. Perspectives of research and development: Collection of scientific articles. SAUL Publishing Ltd, Dublin, Ireland, 2017. P. 129-131.

10. Pet'ko Lyudmila. The "Case Study" Method as Means of Formation of a Professionally Oriented Foreign Language Teaching Environment in University Conditions. Intellectual Archive. 2015. Volume 4. Num. 4 (July). Series "Education \& Pedagogy". Toronto : Shiny World Corp. PP. 48-65.

11. Shkolna Maria. Pedagogical conditions for upbringing social maturity of students' agricultural colleges. Intellectual Archive. Toronto: Shiny World Corp. (Canada). 2017. September/October. Vol. 6. No. 5. PP. 79-85. 


\title{
The Specifics of Teenager's Socialisation in Orphanage "Perlynka"
}

\author{
Petrova Svitlana \\ ORCID https://orcid.org/0000-0001-8911-7448 \\ Municipal Educational Institution «Orphanage «Perlynka», director
}

\author{
PhD applicant \\ Institute of Problems on Education of the National Academy of Educational \\ Sciences of Ukraine (Ukraine, Kyiv)
}

\begin{abstract}
This articles gives a theoretical specifics of teenager's socialisation in "Perlynka". A theoretical analysis of philosophical, psychological, and pedagogical literature in this issue enables us to specify the notion "socialisation of an orphan". We think that socialisation of an orphan is the process of the formation and the development of a personality which aims at mastering the activity while being influenced by an environment. It involves learning ways of social lifestyle, a system of social links, ideas and values, behavioural standards. They develop their personal traits, form their activeness and develop their own lifestyle and obtain a social experience during the process of socialisation of a personality. The efficiency of socialisation depends on such conditions as the agreement between a social practice and the nature, aims, and sense of an educative influence on a child; the total impact of objective and subjective factors; the intensity of the education and self-education; the activeness of accompanying process such as learning and education; the intensity of the impact on "inner world" of orphans (the system of motives, needs, emotions, intelligence, will); the combination of pedagogical impact and the degree of the development of verbal and sensor processes of students; the intensity and the quality of relations (the communication between orphans).

Identified two groups of factors which directly influence on the process of the formation of an orphan's personality. Referred to the first groups the following: a social orphanage, the specifics of the fosters (the lack of self confidence, inferiority complex, the feeling of social remoteness, the lack of skills of the communication which goes beyond conventional situation, the immaturity of inner position, the loss of the interest to learning, the inclination to mental disorder, the orientation to adaptation, etc.; difficulties of socialisation (the lack of individual and social experience which is obtained while being raised in a biological family, mistakes of the upbringing and the full absence of social experience; difficulties which are linked to understanding and doing social roles which leads to the refusal from the role, misunderstanding of its social value). These factors complicate the process of the formation of a teenager's personality at an orphanage.

The second group of factors includes: the sensitivity of a teenager to the process of the personality's formation; the peculiarities of organisational and pedagogical functioning of orphan asylum "Perlynka".

Key words: the formation of a personality, the specifics of the process of the formation of a personality, social orphanage, teenagers, orphan asylum "Perlynka".

Актуальність дослідження. Реформування системи освіти на засадах особистісно орієнтованого підходу актуалізує необхідність посилення уваги науковців до формування дитини як активного суб' єкта життєдіяльності, здатного до елементарних форм відповідального самовизначення, самореалізації. У цьому контексті актуальності
\end{abstract}


набуває проблема становлення особистості підлітка в умовах дитячого будинку, оскільки більшість вихованців цих установ - соціальні сироти, які потребують особливої уваги 3 боку суспільства.

Проблема становлення особистості знайшла широке відображення в працях психологів та педагогів (І. Бех, Л. Божович, І. Зязюн, Л. Кольберг, Т. Кравченко, О. Коберник, А. Макаренко, Г. Олпорт, К. Роджерс, В. Сухомлинський, О. Сухомлинська, Е. Фромм, К. Хорні та інші).

Питання виховання учнів в закладах інтернатного типу знайшло відображення в працях вчених-педагогів: Н. Вишнівської, О. Голуб, Л. Канішевської, Б. Кобзаря, Й. Лангмейєра, 3. Матейчека, В. Мухіної, Г. Покиданова, А. Поляничко, А. Прихожан, С. Свириденко, Н. Толстих та ін.

Отже, незважаючи на широке відображення проблеми в спеціальній літературі, такий iї аспект, як специфіка становлення особистості підлітка в умовах дитячого будинку, не знайшов широкого відображення. Тому метою статті визначено специфіку соціалізації підлітка в умовах дитячого будинку.

Виклад основного матеріалу. Теоретичний аналіз філософської, психологічної, педагогічної літератури з проблеми дослідження дав змогу уточнити сутність поняття «становлення особистості дитини-сироти» як процес формування i розвитку особистості, який спрямований на опанування діяльністю під впливом соціуму, що включає засвоєння способів соціального життя, системи соціальних зв'язків, ідей і цінностей, норм поведінки. У процесі становлення особистості відбувається розвиток особистісних якостей, формується активність особистості, а також виробляється власний стиль життя та набувається соціальний досвід.

Створений І. Бехом варіант особистісно орієнтованого підходу до планомірного виховання підростаючої особистості справедливо позиціонується як нова освітньовиховна філософія. В іiі рамках вихованець із самого початку взаємодії з дорослим повинен усвідомлювати себе як особистість, опановуючи потребами, мотивами, емоціями як рушійними силами його суспільно значущої поведінки. Основою ефективного виховання $є$ наукове розуміння становлення особистості. Домінуючий орієнтир у вихованні особистості - ïi комунікативна природа: спілкування є загально психологічною основою виховання особистості [2]. 
Ефективність становлення особистості підлітка залежать від наступних умов: відповідності соціальної практики та характеру (спрямованості, змісту) виховного впливу на вихованця; сукупної дії об'єктивних та суб'єктивних чинників; інтенсивності виховання і самовиховання; активності супутніх процесів - навчання і розвитку; інтенсивності дії на «внутрішню сферу» вихованців (систему мотивів, потреб, емоцій, інтелекту, волі); поєднання педагогічної дії та рівня розвитку вербальних та сенсомоторних процесів вихованців; інтенсивності та якості взаємовідносин (спілкування між самими вихованцями).

Дослідження специфіки становлення особистості підлітка в умовах дитячого будинку «Перлинка» вимагає врахування двох груп чинників, які безпосередньо впливають на цей процес.

До першої групи належать такі чинники, як: соціальне сирітство, специфіка контингенту вихованців, труднощі соціалізації.

Слід зазначити, що у дитячих будинках зосереджено специфічний контингент дітей . Переважна більшість вихованців - це педагогічно занедбані діти з негативним життєвим досвідом, яким властиві проблеми як особистісного, так і міжособистісного характеру: невпевненість у собі, комплекс неповноцінності, почуття соціальної відчуженості, відсутність навичок позаситуативного спілкування, несформованість внутрішньої позиції, втрата інтересу до навчання, схильність до нервових розладів, орієнтація на пристосування тощо [7, с. 293; 9; 10].

До інтелектуальних, поведінкових, мотиваційних характеристик вихованців дитячого будинку додаються проблеми, пов'язані із здоров'ям дитини. Фактично здорових дітей в дитячих будинках майже немає, діти мають хронічні захворювання. Крім того, у багатьох дітей спостерігається інтелектуальна недостатність - затримка психічного розвитку.

Основними труднощами соціалізації вихованців дитячих будинків є: брак індивідуального, соціального досвіду, що обумовлений специфікою спілкування в біологічній сім’̈, помилками у вихованні або повною відсутністю соціального досвіду; труднощі, пов’язані з розумінням та виконанням соціальних ролей, що призводить до заперечення ролі, нерозуміння іiї соціальної значущості, ухиляння від соціальних ролей [8, c. $60 ; 11 ; 12 ; 13 ; 14 ; 15 ; 17 ; 19 ; 20]$. 
Дослідниця Л. Канішевська зазначає, що важливими показниками реалізації функції подолання труднощів соціалізації вихованців інтернатних закладів є: активна життєва позиція вихованця у процесі вирішення соціальних проблем, стійкість до несприйнятливих соціальних впливів, готовність до адекватного прийняття й вирішення виникаючих соціальних проблем, збереження власної індивідуальності [8, с. 60].

Отже, специфіка контингенту вихованців дитячих будинків; труднощі соціалізації суттєво ускладнюють процес становлення особистості.

Підлітковий вік - сенситивний для становлення особистості, оскільки характеризується засвоєнням суспільних норм і функцій; оволодінням соціальними ролями; моральною рефлексією; підвищеною сприятливістю до ціннісних взаємин 3 оточуючими.

У той же час слід зауважити, що прояви підліткового віку є серйозною соціальнопедагогічною проблемою.

Як зазначає I. Булах, у багатьох підлітків переживання кризи пов'язане із зовнішніми проявами негативізму й егоцентризму. Підлітковий егоцентризм, на думку вченої, являє собою неадекватно сильну сконцентрованість на власній особистості. Однак у переважної більшості учнів егоцентризм має тимчасовий характер і не досягає значної виразності [3, с. 81-81].

На думку І. Беха, підліткові властиве почуття дорослості, тобто ставлення до себе самого як до дорослого, його уявлення чи відчуття себе певною мірою дорослим. Почуття дорослості в цьому віці не є обов'язково усвідомленим. Воно виступає для підліткового віку специфічною формою самосвідомості, соціальною за своїм змістом. Дослідник доводить, що першим і основним показником цього почуття є виникнення у підлітка потреби в ставленні до нього не як до дитини, а як до дорослого. У разі ігнорування цієї потреби педагогом, підлітки виявляють образу, різні форми протесту: неслухняність, грубість, упертість, протиставлення себе дорослим чи товаришам, зіткнення й конфлікти. Другим показником почуття дорослості, зазначає І. Бех, $\epsilon$ наявність у підлітків прагнення до самостійності і бажання захистити деякі сфери свого життя від втручання дорослих. Третій показник наявності у підлітків почуття дорослості - вироблення власної лінії поведінки, іноді всупереч дорослим чи товаришам [1]. 
Важливим чинником, що впливає на становлення особистості підлітка в умовах дитячого будинку «Перлинка» $\epsilon$ особливості його організаційно-педагогічного функціонування [4].

Дитячий будинок «Перлинка» розташований у сприятливій курортній зоні міста на березі моря Одеської області; має необхідну кількість приміщень та обладнання для організації освітнього процесу, проживання та харчування вихованців, проведення позаурочної роботи, трудового навчання і виховання та забезпечення належних умов для роботи педагогічного та медичного персоналу і проведення лікувально-профілактичних заходів.

Режим дня, розклад занять складені з урахуванням тривалості перебування дітей у закладі з дотриманням педагогічних і санітарно-гігієнічних вимог, затверджені рішенням педагогічної ради закладу та погоджуються з відповідним органом управління освітою і територіальною установою державної санітарно-епідеміологічної служби. Режим роботи і розклад занять забезпечують науково-обгрунтоване співвідношення навчання, праці і відпочинку вихованців.

Архітектура будинку сприяє розвитку почуття свободи, краси і піднесення. Перший і другий поверхи комплексу розділені скляною підлогою, яка розширює простір будови і робить його єдиним простором.

Педагоги дитячого будинку «Перлинка» у своїй практичній діяльності дотримуються правил особистісно орієнтованої взаємодії з вихованцями: ставляться до дитини як до найбільшої цінності, виявляють взаємну відкритість, відвертість; «допомагають вихованцю зрозуміти власну цінність через відчуття довіри, поваги, любові, розвиток почуття власної гідності» [5, с. 377-378].

Висновки. Визначено специфіку становлення особистості підлітка в умовах дитячого будинку. Виявлено дві групи чинників, які безпосередньо впливають на процес становлення особистості дитини-сироти в умовах дитячого будинку. До першої групи чинників відносяться наступні: соціальне сирітство, специфіка контингенту вихованців; труднощі соціалізації. Ці чинники значно ускладнюють процес становлення особистості підлітка в умовах дитячого будинку. Друга група чинників включає: сенситивність підліткового віку щодо становлення особистості; особливості організаційнопедагогічного функціонування дитячого будинку «Перлинка». 
Аналіз проблеми становлення особистості підлітка в умовах дитячого будинку «Перлинка» потребує подальшого й різнопланового дослідження, зокрема, теоретичного обгрунтування та експериментальної перевірки організаційно-педагогічних умов становлення особистості підлітка в умовах дитячого будинку.

\section{References}

1. Bekh I.D. Vykhovannia osobystosti : pidruchnyk. [Personality upbringing: textbook] Kyiv: Lybid, 2008. 848 p.

2. Bekh I.D. Vykhovannia osobystosti. U 2 kn. Kn. 1. Osobystisno oriientovanyi pidkhid: teoretyko-tekhnolohichni zasady. [Upbringing of the person. 2 books Kn. 1. Personally oriented approach: theoretical and technological principles] Kyiv: Lybid, 2003. 280 p.

3. Bulakh I.S. Psykholohiia osobystisnoho zrostannia pidlitka : Monohrafiia. [The psychology of a teenager's personal growth] Kyiv: NPU im. M. P. Drahomanova, 2003. 340 p.

4. Drohan O.S., Petrova S.M. Dytiachyi budynok "Perlynka»: shkola osobystisnooriientovanoi pedahohiky (kroky poshuku, stanovlennia, rozvytku) : navchalno-metodychnyi posibnyk. [Children's home "Pearl": a school of person-oriented pedagogy (steps of search, formation, development): a teaching manual] Kyiv - Odesa - Chernivtsi: Bukrek, 2017. 184 p.

5. Kanishevska L.V. Vzaiemodiia pedahohiv i vykhovantsiv na osnovi pedahohichnoi pidtrymky yak umova vykhovannia sotsialnoi zrilosti starshoklasnykiv shkil-internativ [Interaction of teachers and pupils on the basis of pedagogical support as a condition for the education of social maturity of senior pupils of boarding schools]. Teoretyko-metodychni problemy vykhovannia ditei ta uchnivskoi molodi: zb. nauk. prats. Issue 13. Kn. 1. KamianetsPodilskyi: Vydavets Zvoleiko D.H., 2009. P. 369-379.

6. Kanishevska L.V. Doslidzhennia problemy vykhovannia sotsialnoi zrilosti starshoklasnykiv shkil-internativ. [The research of the problem of fostering social maturity in senior students of orphan boarding schools]. Pedahohichnyi almanakh: zb. nauk. prats. Kherson KVNZ "Khersonska akademiia neperervnoi osvity", 2012. Issue 16. P. 213-220.

7. Kanishevska L.V. Doslidzhennia problemy pidhotovky starshoklasnykiv shkilinternativ do samostiinoho zhyttia. [The research of the problem of preparing senior students of orphan boarding schools to their own life]. Teoretyko-metodychni problemy vykhovannia ditei ta uchnivskoi molodi: zb. nauk. prats. Kirovohrad: Imeks - LTD, 2013. Issue. 17, Kn. 1. P. 293-299.

8. Kanishevska L.V. Sotsializatsiia ta osoblyvosti yii proiavu u vykhovantsiv zahalnoosvitnikh shkil-internativ [Socialization and peculiarities of its manifestation among pupils of general boarding schools]. Teoretychni pytannia kultury, osvity ta vykhovannia: zb. nauk. prats Issue 46. Kyiv: Vyd. tsentr KNLU, 2012. P. 57-61.

9. Petrova S.M. Proekt «Model innovatsiinoho navchalnoho zakladu «Dytiachyi budynok «Perlynka» [Model of Innovative Educational Institution "Orphanage "Perlynka"] [Web site]. - 2010. - Access mode: http://perlinka.org.ua/en/zhemchuzhinka/ eksperimentalnaya-rabota-detskogo-doma/563-model-innovatsijnogo-navchalnogo-zakladu. 
10. Petrova Svitlana. Rationale for innovation orphanage model. The pedagogical process: theory and practice (series: Pedagogy) No 4 (55), 2016. P. 103-108.

11. Pet'ko L.V. Hurtok "Mandrivnyky» ta formuvannia sotsialnoi aktyvnosti molodshykh shkoliariv [The circle "Travellers" and forming social activities in primary school children]. Pedahohichnyi almanakh: zb. nauk. pr. ; redkol. V.V.Kuzmenko ta in. - Kherson: KVNZ «Khersonska akademiia neperervnoi osvity», 2018. Issue 37. P. 34-39.

12. Pet'ko L.V. Derzhavnyi standart pochatkovoi osvity u rakursi formuvannia sotsialnoi aktyvnosti dytyny [The State Standard for elementary education in the views of social activity formation in a child]. Naukovi zapysky Berdianskoho derzh. ped. un-tu. Seriia: Pedahohika: zb. nauk. pr. — Berdiansk: BDPU, 2018. - Issue 1. - P. 92-97.

13. Pet'ko L. V. Sotsialno-komunikatyvna aktyvnist pidlitkiv: teoriia $i$ praktyka [Monohrafiia] [Social and communicative activity of adolescents: theory and practice [Monograph]. Kyiv: VMURoL "Ukraina", 2010. 268 p.

14. Pet'ko L. V. Turyzm - sprava zahoplyuyucha [Tourism is a fascinating matter]. Rad. shkola. - 1990. - No 11. - P. 25-29.

15. Kanishevska Liubov. The formation of the immunity to the use of psychoactive substances by senior teenagers as the tendency of the formation of the life safety // Topical is sueso feducation: Collective monograph. - Pegasus Publishing, Lisbon, Portugal, 2018. P. 231-243.

16. Kanishevska L.V., Stadnik N.V. Theoretical aspects of the concept «responsibility» in works by foreign researchers. Perspectives of research and development: Collection of scientific articles. SAUL Publishing Ltd, Dublin, Ireland, 2017. P. 129-131.

17. Pet'ko Lyudmila. Environmental approach in the formation of social activity in primary school children. Problems of modern science: Collection of scientific articles. - Fadette editions, Namur, Belgium, 2018. - PP. 190-194.

18. Shkolna Maria. Pedagogical conditions for upbringing social maturity of students' agricultural colleges. Intellectual Archive. Toronto: Shiny World Corp. (Canada). 2017. September/October. Vol. 6. No. 5. PP. 79-85.

19. Ternopilska V.I. The role of self-government in development of leadership qualities among students. Problems of development modern science: theory and practice: Collection of scientific articles. - EDEX, Madrid, España, 2016. - P. 327-330.

20. Hlushko L., Ternopilska V. Self-confidence: theoretical analysis. Problems of the development of modern science: theory and practice: Collection of scientific articles. - EDEX, Madrid, España, 2018. P. 192-196. 


\section{Translation of the Title, Abstract and References to the Author's Language}

УДК: 37.018.32.015.31-058.862(043.5)

Петрова Світлана. Специфіка становлення особистості підлітка в умовах дитячого будинку «Перлинка».

У статті теоретично обгрунтовано специфіку становлення особистості підлітка в умовах дитячого будинку «Перлинка». Виявлено дві групи чинників, які безпосередньо впливають на цей процес. До першої групи чинників відносяться наступні: соціальне сирітство, специфіка контингенту вихованців (педагогічно занедбані діти з негативним життєвим досвідом, яким властиві проблеми як особистісного, так і міжособистісного характеру: невпевненість у собі, комплекс неповноцінності, втрата інтересу до навчання, почуття соціальної відчуженості, схильність до нервових розладів, орієнтація на пристосування тощо); труднощі соціалізації. Друга група чинників включає: сенситивність підліткового віку щодо становлення особистості; особливості організаційно-педагогічного функціонування дитячого будинку «Перлинка».

Ключові слова: становлення особистості, специфіка становлення особистості, соціальне сирітство, підлітки, дитячий будинок «Перлинка».

\section{Лimepamypa}

1. Бех І. Д. Виховання особистості : підр. Київ: Либідь, 2008. 848 с.

2. Бех І. Д. Виховання особистості. У 2 кн. Кн. 1. Особистісно орієнтований підхід: теоретико-технологічні засади. Київ: Либідь, 2003. 280 с.

3. Булах І. С. Психологія особистісного зростання підлітка : монографія. Київ: НПУ ім. М. П. Драгоманова, 2003. 340 с.

4. Дроган О. С., Петрова С. М Дитячий будинок «Перлинка»: школа особистісноорієнтованої педагогіки (кроки пошуку, становлення, розвитку) : навч.-метод. посібник. Київ - Одеса - Чернівці: Букрек, 2017. 184 с.

5. Канішевська Л. В. Взаємодія педагогів і вихованців на основі педагогічної підтримки як умова виховання соціальної зрілості старшокласників шкіл-інтернатів. Теоретико-методичні проблеми виховання дітей та учнівської молоді : зб. наук. пр. Вип. 13. Кн. 1. Кам'янець-Подільський : Видавець Зволейко Д. Г. , 2009. С. 369-379.

6. Канішевська Л.В. Дослідження проблеми виховання соціальної зрілості старшокласників шкіл-інтернатів. Педагогічний альманах : зб. наук. пр. Херсон КВНЗ «Херсонська академія неперервної освіти», 2012. Вип. 16. С. 213-220.

7. Канішевська Л.В. Дослідження проблеми підготовки старшокласників шкілінтернатів до самостійного життя. Теоретико-методичні проблеми виховання дітей та учнівської молоді: зб. наук. пр. Кіровоград: Імекс - ЛТД, 2013. Вип. 17, Кн. 1. С. 293-299.

8. Канішевська Л.В. Соціалізація та особливості ऑii прояву у вихованців загальноосвітніх шкіл-інтернатів. Теоретичні питання культури, освіти та виховання : зб. наук. праць Вип. 46. Київ: Вид. центр КНЛУ, 2012. С. 57-61.

9. Петрова С.М. Проект «Модель інноваційного навчального закладу «Дитячий будинок «Перлинка» [Електронний ресурс]. - 2010. - Режим доступу: 
http://perlinka.org.ua/en/zhemchuzhinka/eksperimentalnaya-rabota-detskogo-doma/563model-innovatsijnogo-navchalnogo-zakladu.

10. Петрова Світлана. Обгрунтування моделі інноваційного дитячого будинку. The pedagogical process: theory and practice (series: Pedagogy). № 4 (55), 2016. C. 103-108.

11. Петько Л.В. Гурток «Мандрівники» та формування соціальної активності молодших школярів. Педагогічний альманах: зб. наук. пр. ; редкол. В.В.Кузьменко та ін. Херсон: КВНЗ «Херсонська академія неперервної освіти», 2018. Вип. 37. С. 34-39.

12. Петько Л.В. Державний стандарт початкової освіти у ракурсі формування соціальної активності дитини. Наукові записки Бердянського державного педагогічного університету. Серія : Педагогіка : зб. наук. праць. Бердянськ: БДПУ, 2018. Вип. 1. С. 92-97.

13. Петько Л. В. Соціально-комунікативна активність підлітків: теорія і практика [Монографія]. К.: ВМУРоЛ «Україна». 2010. 268 с.

14. Петько Л. В. Туризм - справа захоплююча. Рад. школа. 1990. № 11. С. 25-29.

15. Kanishevska Liubov. The formation of the immunity to the use of psychoactive substances by senior teenagers as the tendency of the formation of the life safety // Topical is sueso feducation: Collective monograph. - Pegasus Publishing, Lisbon, Portugal, 2018. P. 231-243.

16. Kanishevska L.V., Stadnik N.V. Theoretical aspects of the concept «responsibility» in works by foreign researchers. Perspectives of research and development: Collection of scientific articles. SAUL Publishing Ltd, Dublin, Ireland, 2017. P. 129-131.

17. Pet'ko Lyudmila. Environmental approach in the formation of social activity in primary school children. Problems of modern science: Collection of scientific articles. - Fadette editions, Namur, Belgium, 2018. - PP. 190-194.

18. Shkolna Maria. Pedagogical conditions for upbringing social maturity of students' agricultural colleges. Intellectual Archive. Toronto: Shiny World Corp. (Canada). 2017. September/October. Vol. 6. No. 5. PP. 79-85.

19. Ternopilska V.I. The role of self-government in development of leadership qualities among students. Problems of development modern science: theory and practice: Collection of scientific articles. - EDEX, Madrid, España, 2016. - P. 327-330.

20. Hlushko L., Ternopilska V. Self-confidence: theoretical analysis. Problems of the development of modern science: theory and practice: Collection of scientific articles. - EDEX, Madrid, España, 2018. P. 192-196. 


\title{
Readiness for Stage Partnership in Vocal-Ensemble Performance as a Vector in Professional Training Music Teacher
}

\author{
Komarovska Oksana \\ ORCID https://orcid.org/0000-0002-3679-9673 \\ Doctor of Sciences in Pedagogy \\ Head of Aesthetic and Art Education Laboratory of the Institute of Problems \\ on Education of the National Academy of Educational Sciences of Ukraine
}

\author{
Huang Hanjie \\ ORCID http://orcid.org/0000-0003-3466-1539 \\ Postgraduate student (China) \\ Dragomanov National Pedagogical University (Ukraine, Kyiv)
}

\begin{abstract}
The article presents a theoretical analysis of the phenomenon "stage partnership" in the way of its understanding as social and artistic phenomena. The component structure of readiness for it as integral personal quality of students-musicians (axiological, cognitive-reflexive, activity-operational, motivational-volitional and communicative components) is revealed. The phenomenon of readiness is studied in the context of vocalensemble performance. The pedagogical potential of vocal-ensemble music making in a small cast of participants (duets) is described.

The authors substantiate the methodology of forming readiness for stage partnership (a complex of forms and methods that show their effectiveness at various stages of the educational process - motivation and informative saturation, practical-implementation, reflexive-strategic. The hierarchy of pedagogical conditions for the effective implementation of the methodology is determined. The main pedagogical condition is marked the creation of an entire musical-communicative educational environment subordinated to a complex of local microenvironments that provide the implementation of the main. The experimental data of studying readiness for stage partnership in future Music teachers is presented.

Key words: stage partnership, readiness for stage partnership, vocal-ensemble performance, future Music teacher, methodology of formation.

Актуальность исследования. Глобализация и информатизация всех сфер жизни, кроме позитива, имеют и негативные последствия. Это проявляется в отторжении человека от общения с другими людьми, в ограничении его возможности вести диалог. В то же время, каждая национальная культура и общество в целом нуждаются в профессионалах, способных творить эту культуру именно через диалог и взаимопонимание (о чем идет речь во многих документах ЮНЕСКО). В основе культуры всегда стояло искусство. Среди его видов музыка выделяется способом
\end{abstract}


воздействия на личность, благодаря процессуально-интонационной природе и способности моделировать эмоциональные процессы человека (Б. Асафьев, М. Каган, Б. Яворский). Диалог в обществе, насыщенном противоречиями, обостряет проблемы толерантности и взаимопонимания. Возрастает внимание к партнерству через искусство.

В связи с этим, в музыкальном творчестве на первый план выходит ансамблевое исполнительство как публичное действие, в котором у исполнителей интенсивно формируется готовность к сценическому партнерству. Ансамбль актуализирует достижение художественного результата партнерами в поисках интерпретации музыкальных образов и полноценном донесении их до слушателя-зрителя.

Цель статьи - обозначить теоретические предпосылки и методические позиции формирования готовности к сценическому партнерству у музыкантов.

Изложсене основного материала. Понятие партнерства и готовности к нему в любой профессиональной сфере все активнее привлекает внимание ученых (Е. Афонина, С. Гончаренко, С. Оруджева, А. Солодкая, В. Цвих). Профессиональная подготовка музыканта-педагога также освещается в исследованиях (Т. Бодрова, Вей Чунг, А. Козырь, Г. Падалка, О. Реброва, У Ифан, Чжан Яньфен, О. Щолокова и др.). Bсе больше привлекает вокальная подготовка студентов-музыкантов (В. Антонюк, Л. Василенко, Н. Гребенюк, А. Менабени, Цзинь Нань и др.). Как самодостаточный художественно-педагогический феномен рассматривается вокально-ансамблевое исполнительство (Т. Ланина, С. Черникова, Н. Фоломеева и др.). Партнерство исследуется преимущественно как составляющая мастерства актера драматического театра. Относительно музыканта-вокалиста более детально изучается актерское мастерство певца (Е. Ерошенко, С. Гмырина, Н. Гребенюк О. Оганезова-Григоренко), что соприкасается со сценическим партнерством. Но эти понятия не тождественны; дефиниция партнерства концентрирует внимание на совместной деятельности, способности со-творить в команде.

Сценическое партнерство в музыкальном искусстве - это синтез коммуникации и исполнительства, который охватывает восприятие произведений и их анализинтерпретацию с последующей сценической презентацией на субъект-субъектной основе. Таким образом, сценическое партнёрство определяем как систему 
многогранных взаимодействий субъектов творческого процесса, отраженных в балаансе решений художественного образа кааждым партнёром, которые принимают его как личностную ценность, т.е. сценическое партнёрство состоит из трёх фаз: подготовительной, собственно выступления, осмысления результата. Следовательно, готовность к сценическому партнерству - это интегральное личностное качество музыканта - ансамблевого исполнителя, которое охватывает его ценности в музыкальном искусстве и в ансамблевом исполнительстве, мотивацию к творческому взаимодействию, волю к реализации замысла, опыт исполнительской деятельности в ансамблях.

Наиболее действенным видом ансамблей является вокальный ансамбль, в котором «музыкальным инструментом» предстает певческий голос; голос наиболее тесно связан с процессуальностью выражения чувств и потому мгновенно реагирует на самые тонкие изменения в эмоциональном состоянии человека $[3 ; 4 ; 12]$, воплощает замысел как непосредственное интонирование смыслов [1]. Для формирования готовности к сценическому партнерству эффективно вокальное музицирование в небольших составах - дуэтах, трио. Они дают возможность полнее проявить индивидуальность на фоне воплощения общей концепции. Интерпретация небольшим составом опирается на диалог участников - в отличие от преимущественной монолитности ансамблей с большим числом исполнителей или хорового коллектива. Во время публичного выступления одновременно вводятся в действие певческие умения параллельно с навыками сценической презентации образа $[2 ; 9 ; 10 ; 11 ; 12 ; 13 ; 14]$.

Таким образом, сценическое партнерство охватывает психологическую готовность партнеров к выступлению и взаимодействию во время выступления, на этапе подготовки к нему и его осмысления; умение анализировать музыку; специфические вокальные умения; умение применять элементы сценического партнерства в педагогической практике. Структуру готовности составляют аксиологический, когнитивно-рефлексивный, деятельностно-операционный, мотивационно-волевой и коммуникативний компоненты.

Содержание сценического партнерства позволяет определить диагностический инструментарий для мониторинга этого качества у музыканта, базирующийся на 
ценностно-мотивационном, когнитивно-креативном, операционно-волевом и рефлексивном критериях [7].

Пилотный експеримент (182 студента) показал, что до 80 \% из них никогда не концентрировали внимание на ансамблевых формах в процессе обучения, хотя каждый участвовал в ансамбле; из оставшихся 20 \% опрошенных только некоторые проявили понимание значимости ансамблевого музицирования для профессионального роста. Но практически все опрошенные, даже участвуя в ансамблях, не задумывались именно о партнерской интерпретации музыкального образа.

Более детальное исследование (анкетирование, изучение мотивации, учебной успешности, количественный анализ ансамблевого репертуара и его сценических презентаций, поведения в ситуациях сценического выступления, самооценки студентов и др.) реальной готовности к сценическому партнерству у студентов-музыкантов выявили проблемные зоны и общие тенденции: наиболее полноценно такая готовность проявилась в аксиологическом и мотивационно-волевом компонентах (учитываем, что во время эксперимента студенты ознакомились з проблемой, обратили внимание на репертуар, что в большинстве случаев уже стало толчком мотивации к погружению в проблему); наименее полноценно у студентов изначально был представлен когнитивнорефлексивный компонент готовности.

Непосредственные действия по формированию готовности студентовмузыкантов к сценическому партнерству нацеливались на совершенствование каждого компонента через актуализацию потенциала вокально-ансамблевого исполнительства, а именно на обогащение художественного познания (восприятия, навыков анализа произведений вместе с развитием вокальных способностей и умений); тренинг партнерства (работа над сценической пластикой и мимикой, сценическим движением, невербальным общением, художественной и личностной эмпатией, речевым интонированием, пространственной ориентированностью в мизансценах, остротой и чуткостью реагирования на импровизацию партнера, что придает целостность музыкальному образу); потребность в выступлениях, в частности, преодоление деструктивного сценического волнения на основе специфического общения с публикой; рефлексию значимости сценического партнерства для будущей педагогической деятельности и собственного участия в нем. 
Понятно, что применение конкретных форм и методов работы проходит ряд этапов: мотивирования и информативного насыщения, практико-внедряющий, рефлексивно-стратегический. На этапе мотивирования и информативного насыщения - это занятия по определению самооценки, анонимная игра «Мои партнеры - кто они?», упражнения-моделирования (предвидение) сценического образа, и соответственно методы театрализации, создание игровых ситуаций, межхудожественные ассоциации, тренинг эмоционального слуха. Ha практико-внедряющем этапе - это театрализованные демонстрации, подготовка видеопрезентаций, «режиссерские репетиции», «диалогические инсценизации», актерские этюды (с использованием методов дискуссии, моделирования ситуаций репетиций, тренинг ансамблевого самочувствия). На этапе рефлексивно-стратегическом -экспресс-рефлексии, написание эссе, в применении которых действенными оказались методы неоконченных предложений, прогнозирования трудностей.

Кроме того, для эффективности методики необходимо реализовать педагогические условия как систему, которая охватывает, такие дисциплины, как класс вокала и хорового дирижирования, курсы истории музыки, сольфеджио, психология музыкального творчества и др., а также внеаудиторную концертную деятельность учащихся. Такими условиями предстают как взаимосвязанные стержневое условие (создание целостной музыкально-коммуникативной образовательной среды) и подчиненные ему локальные микросреды, обеспечивающие реализацию стержневого (мотивирования к поиску репертуара, последовательного накопления опыта вокальноансамблевого исполнительства, полихудожественного подхода к созданию вокальноансамблевого сценического образа) [8].

В результате обозначилась положительная, хотя и неоднородная динамика. Наиболее яркие изменения отслежены в развитии инициативности интерпретационной деятельности (продуцирование оригинальных решений, обоснованность предложений); в более полном осмыслении студентами ценности диалога как такового и партнерства музыкантского; в расширении репертуара и устойчивых представлениях о специфике вокально-ансамблевого исполнительства, в техническом мастерстве; саморефлексии и адекватной самооценке, в образовании устойчивых ансамблевых коллективов по 
инициативе студентов. Трудности касались недостаточной самостоятельности и оригинальности художественного мышления и сценического самоконтроля.

Выводы. Проблема сценического партнерства должна быть актуализирована в профессиональном становлении музыканта, а особенно педагога музыканта, поскольку сам феномен содержит важнейшие аспекты как собственно художественной, так и социальной значимости. Однако, ее изучение в отношении будущих учителей музыки пока недостаточно. Обозначенные в статье теоретические и методические векторы на основе привлечения студентов к вокальным ансамблям должны быть дополнены изучением и реализацией потенциала других форм ансамблевого музицирования (инструментального, инструментально-вокального), уточнением психологических особенностей различных количественных составов исполнителей, содержательного обогащения курсов профессиональной подготовки. Все это очерчивает перспективу дальнейших исследований.

\section{References}

1. Asafiev B.V. Muzykalnaia forma kak protsess [Musical form as a process]. Leningrad: Musica, 1971. 376 p.

2. Hmyrina S.V. Stsenichne perevtilennia studenta-vokalista yak pedahohichna problema [Scenic reincarnation of a student-vocalist as a pedagogical problem.]. Naukovyi chasopys NPU imeni M. P. Drahomanova. Seriia № 14. Teoriia i metodyka mystetskoi osvity. Issue 14 (19). Part 1. P. 46-50.

3. Hrebeniuk N.Ye. Vokalno-vykonavska tvorchist: psykholoho-pedahohichnyi ta mystetstvoznavchyi aspekty [Vocal and performing arts: psycho-pedagogical and art-study aspects]: [monohrafiia]. Kyiv: NMAU im. P.I. Chaikovskoho, 1999. 269 p.

4. Komarovska O.A. Mystetska osvita: peredchuttia zmin ta hotovnist uchytelia do $n y k h$ [Artistic education: a premonition of change and a teacher's readiness for them.]. Mystetstvo ta osvita. 2017. No 3. P. 10-15.

5. Komarovska O.A. Stsenichne perevtilennia studenta-vokalista yak pedahohichna problema [Artistic-intonational space of life as a source of values of personality's developing: psychological and pedagogical aspects] // Topical issues of education: Collective monograph. - Pegasus Publishing, Lisbon, Portugal, 2018. - P. 260-280.

6. Komarovska O.A. Khudozhnii obraz tvoru yak proiav obdarovanosti myttsi [Artistic image of the work as a display of gifted past master]. Mystetstvo ta osvita. 2009. No 4. P. 2-6.

7. Khuan Khantsze. Diahnostuvannia hotovnosti maibutnoho vchytelia muzyky do stsenichnoho partnerstva [Diagnostic of the readiness of the future Music teacher to the stage partnership]. Problemy pidhotovky suchasnoho vchytelia: zb. nauk. pr. Umanskoho derzh. ped. un-tu imeni Pavla Tychyny / [red..kol. : Bezliudnyi O.I. ta in.]. Uman: VPTs Vizavi, 2017. Issue 16. P. 184-190. 
8. Khuan Khantsze. Pedahohichni umovy formuvannia hotovnosti maibutnoho vchytelia muzyky do stsenichnoho partnerstva [Pedagogical conditions for forming the readiness of the future Music teacher of to the stage partnership]. Mystetska osvita ta rozvytok tvorchoi osobystosti: zb. nauk. pr. / In-t mystetstvoznavstva, folklorystyky ta etnolohii im..M.T.Rylskoho NAN Ukrainy, Uniwersytet Rzeszowski wydzial Muzyki, Rivnenskyi derzh.humant.un-t. Rivne: Volynski oberehy, 2018. Issue 4. P. 138-144.

9. Petko L.V. Robota nad pisneiu $v$ kursi anhliiskoi movy yak odyn iz zasobiv profesiinoi pidhotovky studentiv humanitarnykh spetsialnostei VNZ [The song in English course as a means of training humanities majors university students']. Inozemni movy. 2011. No. 1. P. 44-48.

10. Petko L.V. Formuvannia profesiino oriientovanoho inshomovnoho navchalnoho seredovyshcha v umovakh universytetu dlia studentiv spetsialnosti «Muzychne mystetstvo» (na prykladi virsha Meri Khovitt «Pavuk i Mukha») [Formation of professionally oriented foreign language teaching environment in the terms of university for students of Music Art specialty (on illustration of a poem "The Spider and the Fly» by Mary Howitt)]. Naukovi zapysky Berdianskoho derzh ped. un-tu. Pedahohichni nauky: zb. nauk. pr. Vyp. 1. Berdiansk: FO-P Tkachuk O.V., 2016. P. 184-190.

11. Pet'ko L.V. Shljahy formuvannja inshomovnoi' sociokul'turnoi' kompetencii' studentiv mystec'kyh special'nostej VNZ u procesi fahovoi' pidgotovky [The Ways of Formation of Foreign Language Socio-Cultural Competence of Students of Music-Pedagogical Specialties in High School in the Process of Professional Teaching]/ Problemy pidgotovky suchasnogo vchytelja: zb. nauk. pr. Umans'kogo derzhavnogo pedagogichnogo universytetu imeni Pavla Tychyny / [red. kol.: Pobirchenko N.S. (gol.red) ta in.]. Uman' : PP Zhovtyj O.O., 2012. Issue 6. Part 3. Ch. 3. P. 57-62.

12. Komarovska O. Art Pedagogics in the Context of Civilizational Change: On the Problems of Teacher Training / Professional Artistic Education and Culture within Modern Global Transformations ; ed. by O.Oleksiuk. Cambridge: Cambridge Scholars Publishing. 2018. PP. 79-85.

13. Pet'ko L.V. Formation of professionally oriented foreign language teaching environment in the conditions of university for students of art specialties. Economics, management, law: problems of establishing and transformation: Collection of scientific articles. - Al-Ghurair Printing \& Publishing LLC, Dubai, UAE, 2016. P. 395-398.

14. Shcholokova O.P. Art and pedagogical designing as a means of improvement of music teacher's professional preparing. Economics, management, law: socio-economical aspects of development: Collection of scientific articles. Volum 2. Edizioni Magi - Roma, Italy. 2016. P. 265-268. 


\section{Translation of the Title, Abstract and References to the Author's Language}

\section{УДК [792.05:005.56]:[784:785]:377:78-071.2}

Комаровська О., Хуан Ханьцзе. Готовність до сценічного партнерства у вокально-ансамблевому виконавстві як вектор професійної підготовки педагогівмузикантів.

У статті подано теоретичний аналіз феномену сценічного партнерства, компонентної структури готовності до нього як інтегральної особистісної якості студентів-музикантів педагогічних університетів. Досліджуваний феномен розглядається в контексті вокально-ансамблевого виконавства. Автори обгрунтовують методику формування готовності до сценічного партнерства (комплекс форм та методів, які виявляють свою дієвість на різних етапах освітнього процесу) визначають ієрархію педагогічних умов іiі ефективного впровадження. Наведено експериментальні дані щодо вивчення готовності до сценічного партнерства у майбутніх учителів музики.

Ключові слова: сценічне партнерство, готовність до сценічного партнерства. Вокально-ансамблеве виконавство, майбутній учитель музики, методика формування.

\section{Комаровская О., Хуан Ханьцзе. Готовность к сценическому партнерству в вокально-ансамблевом исполнительстве как вектор профессиональной подготовки педагогов-музыкантов.}

В статье представлен теоретический анализ феномена сценического партнерства, компонентной структуры готовности к нему как интегрального личностного качества студентов-музыкантов педагогических университетов. Исследуемый феномен рассматривается в контексте вокально-ансамблевого исполнительства. Авторы обосновывают методику формирования готовности к сценическому партнерству (формы и методы, действенные на разных этапах образовательного процесса), определяют иерархию педагогических условий ее эффективного внедрения. Приведены экспериментальные данные изучения готовности к сценическому партнерству у будущих учителей музыки.

Ключевые слова: сценическое партнерство, готовность к сценическому партнерству, вокально-ансамблевое исполнительство, будущий учитель музыки, методика формирования.

\section{Литература}

1. Асафьев Б. В. Музыкальная форма как процесс. Ленинград: Музыка, 1971. $376 \mathrm{c}$.

2. Гмиріна С. В. Сценічне перевтілення студента-вокаліста як педагогічна проблема. Науковий часопис НПУ імені М. П. Драгоманова. Серія № 14. Теорія і методика мистецької освіти. Вип. 14 (19). Ч. 1. С. 46-50.

3. Гребенюк Н. С. Вокально-виконавська творчість: психолого-педагогічний та мистецтвознавчий аспекти: [монографія]. Київ: НМАУ ім. П.І. Чайковського, 1999. 269 c.

4. Комаровська О.А. Мистецька освіта: передчуття змін та готовність учителя до них. Мистецтвво та освіта. 2017. № 3. С. 10-15. 
5. Комаровська О.А. Художньо-інтонаційний простір життя як джерело цінностей підростаючої особистості // Topical issues of education: Collective monograph. - Pegasus Publishing, Lisbon, Portugal, 2018. - P. 260-280.

6. Комаровська О.А. Художній образ твору як прояв обдарованості митця. Мистеитво та освіта. 2009. № 4. С. 2-6.

7. Хуан Ханьцзе. Діагностування готовності майбутнього вчителя музики до сценічного партнерства. Проблеми підготовки сучасного вчителя: зб. наук. пр. Уманського держ. пед. ун-ту імені Павла Тичини / [ред..кол. : Безлюдний O.I. та ін.]. Умань: ВПЦ Візаві, 2017. Вип. 16. С. 184-190.

8. Хуан Ханьцзе. Педагогічні умови формування готовності майбутнього вчителя музики до сценічного партнерства. Мистецька освіта та розвиток творчої особистості: зб. наук. пр. / Ін-т мистецтвознавства, фольклористики та етнології ім..М.Т.Рильського НАН України, Uniwersytet Rzeszowski wydzial Muzyki, Рівненський держ.гумант.ун-т. Рівне: Волинські обереги, 2018. Вип. 4. С. 138-144.

9. Петько Л.В. Робота над піснею в курсі англійської мови як один із засобів професійної підготовки студентів гуманітарних спеціальностей ВНЗ. Іноземні мови. 2011. № 1. С. 44-48.

10. Петько Л.В. Формування професійно орієнтованого іншомовного навчального середовища в умовах університету для студентів спеціальності «Музичне мистецтво» (на прикладі вірша Мері Ховітт «Павук і Муха»). Наукові записки Бердянського держ пед. ун-ту. Педагогічні науки: зб. наук. пр. Вип. 1. Бердянськ: ФОП Ткачук О.В., 2016. С. 184-190.

11. Петько Л.В. Шляхи формування іншомовної соціокультурної компетенції студентів мистецьких спеціальностей ВНЗ у процесі фахової підготовки. Проблеми підготовки сучасного вчителя: зб. наук. пр. Уманського державного педагогічного університету імені Павла Тичини / [ред. кол.: Побірченко Н.С. (гол.ред) та ін.]. - Умань : ПП Жовтий О.О., 2012. Випуск 6. Частина 3. - С. 57-62.

12. Komarovska O. Art Pedagogics in the Context of Civilizational Change: On the Problems of Teacher Training / Professional Artistic Education and Culture within Modern Global Transformations ; ed. by O.Oleksiuk. Cambridge: Cambridge Scholars Publishing. 2018. PP. 79-85.

13. Pet'ko L.V. Formation of professionally oriented foreign language teaching environment in the conditions of university for students of art specialties. Economics, management, law: problems of establishing and transformation: Collection of scientific articles. - Al-Ghurair Printing \& Publishing LLC, Dubai, UAE, 2016. P. 395-398.

14. Shcholokova O.P. Art and pedagogical designing as a means of improvement of music teacher's professional preparing. Economics, management, law: socio-economical aspects of development: Collection of scientific articles. Volum 2. Edizioni Magi - Roma, Italy. 2016. P. 265-268 
DOI 10.32370/2018_09_8

\title{
Establishing Patterns of Formation and Distribution of Primes to Infinity (Riemann Hypothesis)
}

\author{
Rustem Mustafaev
}

\begin{abstract}
The work analyzed the formation of prime numbers in connection with complex odd numbers, a formula for determining primes to infinity was established.

Prime numbers, the location of which they tried to explain with the help of the asymptotic distribution law of primes, are important in cryptography, navigation, and simulation, that is, their definition is of practical importance.

Keywords: Pr (prime); S - (complex number); A - group; S "5"; Z - group; D - group; forming residue; absolute vector I $\vec{a} \mathrm{I}$; the foundation; - ; root; square root; in function Pr; subgroup S "33"; set of X; square odd; $\mathrm{n}$ orders; Pr function "13"; complex squares; increment $(\Delta \mathrm{n})$; Q - values; $\Delta \mathrm{n}=\mathrm{n}_{2}-\mathrm{n}_{1} ; \mathrm{n}$ - even degree; combining number; $\mathrm{S}[\mathrm{L}]$; intermediate complex; identification; increments of squares; interval; from "81"; the amount of increments; exclude; $\{\mathrm{P} \mathrm{r} \rightarrow \infty$.
\end{abstract}

Гипотеза Римана о распределении нулей дзета - функции Римана была сформулирована Бернхардом Риманом в 1859 году.

В то время, как никто не видел какой - либо закономерности, описывающей распределение простых чисел, Риман обнаружил некоторую закономерность.... «Основным свойством простых чисел есть невозможность деления на любое иное число ( кроме 1) без остатка. Простое число, назовем Pr, не образуется функцией умножения разных чисел (нечетных), возведением нечетных чисел в степень. Например, 3; 5; 7; 11; 13; 17; 19; 23; 29, и далее, до бесконечности ( $\{\mathrm{P} \mathrm{r} \rightarrow \infty-$ множество простых чисел стремится к бесконечности), - невозможно разделить никакое число так, чтобы получить целое число (кроме себя и «1»).

Это $1 ; 3 ; 5 ; 7 ; 11 ; 13 ; 17 ; 19 ; 23 ; 29 ; 31 ; 37 ; 41 ; 43 ; 47 ; 53 ; 59 ; 61 ; 67 ; 71 ; 73 ; 79 ; 83 ; 89$; $97 ; 101 ; 103 ; 107 ; 109$ и далее до бесконечности.

Значения $15 ; 25 ; 35 ; 45 ; 55 ; 65 ; 75 ; 85 ; 95 ; 105 ; 115$, и далее все, оканчивающиеся на «5» и образованные суммой «Х»- пятизначений, увеличением «5» в n- количество раз, являются цельноделимыми на «5», и являются сложными нечетными числами... 15:5=3; 25:5=5; 35:5=7; 45:5=9; 55:5=11; 65:5=13; 75:5=15; 85:5=17..и далее до $\infty$ по условной формуле: $\mathrm{A}=5 \mathrm{xn}, \mathrm{n}$ - порядковый номер числа сложных $\mathbf{A}$ группы.

Примечание: в формулах: $\mathrm{A}=5 \mathrm{xn} ; \mathrm{A}=5+10 \mathrm{xn}$ и подобных, символ «х» обозначает умножение. 
Также эти числа можно определить в закономерности: $\mathbf{A = 5 + 1 0 x n , ~ г д е ~ « 5 » ~ я в л я е т с я ~}$ точкой отсчета, при $\mathrm{n}=0 \ldots$

A - группу обозначим $\mathbf{S}$ « 5 », $\mathbf{S}$ - сложные числа. Значит, все простые числа $\mathrm{Pr}$, в конце могут иметь (оканчиваться) значения $1 ; 3 ; 7 ; 9 \ldots$

Первым числом в ряду $\operatorname{Pr}$ есть «1»; первым нечетным числом, дающим при делении результат, отличный от числителя, есть «3».

Рассмотрим деление начальных простых чисел на «3».. 5:3=1,6666.. 7:3=2,6666...; $11: 3=3,6666 \ldots ; 13: 3=4.3333 \ldots ; 17: 3=5.6666 \ldots ; 19: 3=6.3333 \ldots ; 23: 3=7.6666 \ldots$; $29: 3=9,6666 \ldots ; 31: 3=10,3333 \ldots ; 37: 3=12.3333 \ldots ; 41: 3=13,6666 ; 43: 3=14,3333 \ldots$; $47: 3=17,6666 \ldots$ Всегда при делении на 3 образуется остаток, 0,3333... или 0,6666...

Узнаем значения чисел при делении которых на «8»; «18»; «28»; «38», любые четные числа с окончанием на «8» и остатке 0,3333 и $0,6666 \ldots$ - образуется значение «3».

$\mathrm{X}: 8,3333 \ldots=3 ; \mathrm{X}=24,999998 \approx 25 ; \mathrm{X}: 8,6666 \ldots=3 ; \mathrm{X} \approx 26 ; \mathrm{X}: 18,3333 \ldots=3 ; \mathrm{X} \approx 55$; $\mathrm{X}: 18,6666 \ldots=3 ; \mathrm{X} \approx 56 ; \mathrm{X}: 28,3333 \ldots=3 ; \mathrm{X} \approx 85 ; \mathrm{X}: 28,666 \ldots=3 ; \mathrm{X} \approx 86 \ldots$ в данных

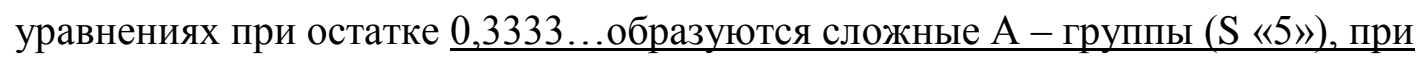
остатке $0,6666 \ldots$ - четные числа. Значение остатка влияет на образование числа, остаток является «образующим», и обозначается как «І $\overrightarrow{\mathrm{I}}$ » (абсолютный $\alpha$ вектор»)... Все простые числа должны содержать определенное количество минимальных простых чисел и остаток как целое число, отличное от этих минимальных значений (назовем его «Х»).

Эти минимальные простые значения являются основой простых чисел, их корнями. Если корень обозначить как - , то $\operatorname{Pr}=-\mathbf{x} \mathbf{n}+\mathbf{X}$, где $\mathbf{n}-$ количество корней, $\mathbf{X}-$ остаток.

Множество простых чисел образуется способом: $\operatorname{Pr}=3 \mathrm{xn}+\mathrm{X} ; \operatorname{Pr}=5 \mathrm{xn}+\mathrm{X} ; \mathrm{Pr}=7 \mathrm{xn}+\mathrm{X}$; $\operatorname{Pr}=11 \mathrm{xn}+\mathrm{X} ; \operatorname{Pr}=13 \mathrm{xn}+\mathrm{X} ; \operatorname{Pr}=17 \mathrm{xn}+\mathrm{X} ; \mathrm{Pr}=19 \mathrm{xn}+\mathrm{X} ; \ldots$ и далее, аналогично, до бесконечности... Возведение в квадратную (вторую) степень (Y= $\operatorname{Pr}$ х $\operatorname{Pr}$ ) любого простого числа (кроме»5») образует нечетное значение с окончанием на «1» или «9»: $11^{2}=121 ; 13^{2}=169 ; 17^{2}=289 ; 19^{2}=361 ; 23^{2}=529 ; 29^{2}=841 ; 31^{2}=961 ; 37^{2}=1369 \ldots$

Рассмотрим деление на «3» небольших значений квадратов простых чисел.

$121: 3=40,3333 \ldots ; 169: 3=56,3333 \ldots ; 289: 3=96,3333 \ldots ; 361: 3=120,3333 \ldots$;

$529: 3=176,3333 \ldots ; 841: 3=440,3333 \ldots ; 961: 3=320,3333 \ldots ; 1369: 3=456,3333 \ldots$

Если начальные значения квадратов делятся на «3» с образованием четных чисел с остатком «I $\overrightarrow{\boldsymbol{a}} \mathbf{I} »=0,3333 \ldots$, тогда верно, что множество простых чисел можно образовать произведением «3» на четные числа в сумме с остатком 0,3333 ... ( \{ 


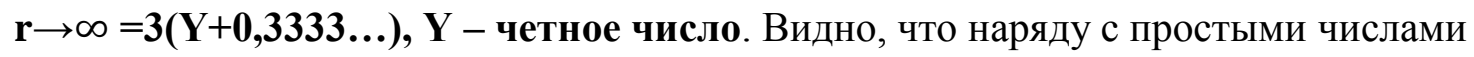
образуются сложные при некоторых значениях «Ү». При Y=16; 40; 56; 96; 120; 176,образуются сложные, как квадраты простых чисел: 49; 121; 169; 289; 361; 529 и другие $: \sqrt{49}=7 ; \sqrt{121}=11 ; \sqrt{169}=13 ; \sqrt{289}=17 ; \sqrt{361}=19 ; \sqrt{529}=23$.

Вывод: для исключения образованного числа в функции $\operatorname{Pr}=3(\mathrm{Y}+0,3333 \ldots)$, Где Y четные числа из ряда ожидаемых простых чисел (Pr), нужно получить корень квадратный из всех образованных чисел и исключить те числа, значение корня квадратного есть целое (при небольших значениях простое число) без остатка......эти числа сложные, как квадраты (вторая степень), простые в большей степени...можно это утверждение отобразить так:

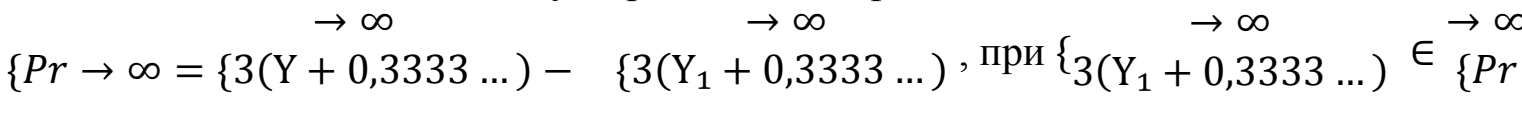

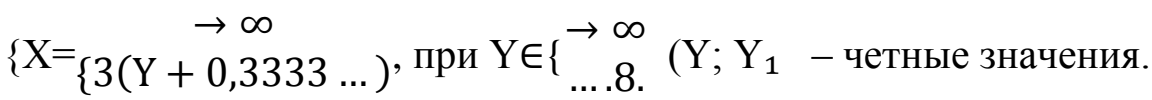

Значения «Ү», оканчивающиеся на «8», образуют сложные «А» группы, поэтому не используются для получения простых чисел. Обозначено как множество $\left\{\begin{array}{l}\rightarrow \infty \\ . . .8 .\end{array}\right.$ Как сложные, не квадратичные числа (квадраты и большие степени простых), образованы следующие: 91; 133; 187; 217; 247; 259; 301; 367; 403; 409; 427; 451; 469; $481 ; 493 ; 511 ; 517, \ldots$.

Рассмотрим образование чисел.

$$
\begin{aligned}
& 3(2+0,3333 \ldots)=7 ; 3(4+0,3333 \ldots)=13 ; 3(6+0,3333 \ldots)=19 ; 3(8+0,3333 \ldots)=\underline{25 \in A} ; \\
& 3((10+0,3333 \ldots)=31 ; 3(12=0,3333 \ldots)=37 ; 3(14+0,3333 \ldots)=53 ; 3(16+0,3333 \ldots)=49 \text {; } \\
& 3(20+0,3333 \ldots)=61 ; 3(22+0,3333 \ldots)=67 ; 3(24+0,3333 \ldots)=73 ; 3(26+0,3333 \ldots)=79 \text {; } \\
& \underline{3(30+0,3333 \ldots)=81} ; 3(32+0,3333 \ldots)=103 ; 3(36+0,3333 \ldots)=109 ; \underline{3(40+0,3333 \ldots)=121} \text {; } \\
& 3(42+0,3333 \ldots)=127 ; 3(44+0,3333 \ldots)=133 ; 3(46+0,3333 \ldots)=149 ; 3(50+0,3333 \ldots)=151 \text {; } \\
& 3(52+0,3333 \ldots)=157 ; 3(54+0,3333 \ldots)=163 ; \underline{3(56+0,3333 \ldots)=169} ; 3(60+0,3333 \ldots) 181 \text {; } \\
& 3(62+0,3333 \ldots)=187 ; 3(64+0,3333 \ldots)=193 ; 3(66+0,3333 \ldots)=199 ; 3(70+0,3333 \ldots)=211 \text {; } \\
& \underline{3(72+0,3333 \ldots)=217} ; 3(74+0,3333 \ldots)=223 ; 3(76+0,3333 \ldots)=229 ; 3(80+0,3333 \ldots)=241 \text {; } \\
& \underline{3(82+0.3333 \ldots)=247} ; 3(84+0,3333 \ldots)=253 ; \underline{3(86+0,3333 \ldots)=259} ; 3(90+0,3333 \ldots)=271 \text {; } \\
& 3(92+0,3333 \ldots)=277 ; 3(94+0,3333 \ldots)=283 ; 3(96+0,3333 \ldots)=289 ; 3(100+0,3333 \ldots)=301 \text {; } \\
& 3(102+0,3333 \ldots)=307 ; 3(104+0,3333 \ldots)=313 ; 3(106+0,3333 \ldots)=319 \ldots \\
& 3(112+0,3333 \ldots)=337 ; 3(114+0,3333 \ldots)=343 ; 3(116+0,3333 \ldots)=349 \text {; }
\end{aligned}
$$

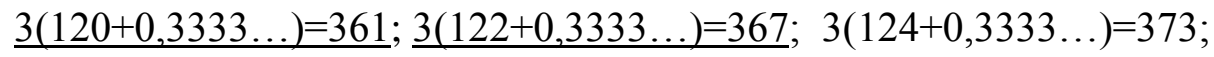

$$
\begin{aligned}
& 3(126+0,3333 \ldots)=379 ; 3(130+0,3333 \ldots)=391 ; 3(132+0,3333 \ldots)=397 \text {; } \\
& \underline{3(134+0,3333 \ldots)=403} ; \underline{3(136+0,3333 \ldots)=409} ; 3(140+0,3333 \ldots)=421 \text {; }
\end{aligned}
$$


$3(142+0,3333 \ldots)=427 ; 3(144+0,3333 \ldots)=433 ; 3(146+0,3333 \ldots)=439$;

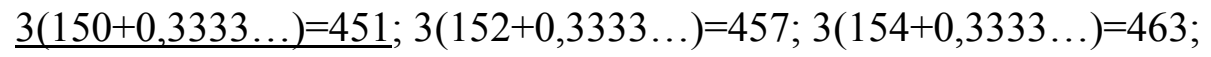

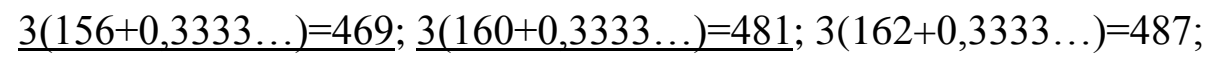

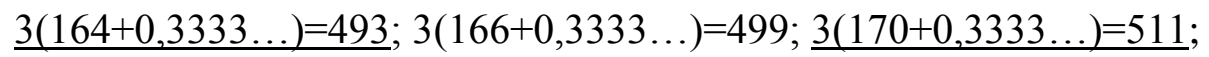

$\underline{3(172+0,3333 \ldots)}=517$

Проверим некоторые значения на деление, принадлежность к сложным...511:7=73;

517:11=47 (образованы произведением простых).

$3(174+0,3333 \ldots)=523 ; \underline{3(176+0.3333 \ldots)=529 ;} \sqrt{529}=23 ; 3(180+0,3333 \ldots)=541 ;$

$3(182+0,3333 \ldots)=547$.

Как сложные, не квадратичные числа, образованы следующие: 91; 133; 187; 217; 247; $259 ; 301 ; 367 ; 403 ; 409 ; 427 ; 451 ; 469 ; 481 ; 493 ; 511 ; 517 \ldots$ Видна закономерность: в функции $\operatorname{Pr}=3(\mathrm{Y}+0,3333 \ldots)$, при значениях «Y», оканчивающихся на «0», образуются числа, оканчивающиеся на «1». Среди них могут быть и квадраты простых чисел.

При значениях «Ү», оканчивающихся на «6», образуются числа, оканчивающиеся на «9». Среди них также могут быть квадраты простых чисел $\left(\mathbf{P r}^{2}\right)$.

Простые числа может образовывать также функция $\mathrm{Pr}=5(\mathrm{Y}+0,6666 \ldots)$ при $\mathrm{Y}-$ четных. В этой функции «образующим» остатком $\mathrm{I} \overrightarrow{\mathrm{a}} \mathrm{I}$ есть $0,6666 \ldots$ К примеру: $5(2+0,6666 \ldots) \approx 13 ; 5(4+0,6666 \ldots) \approx 23 ; 5(6+0,6666 \ldots) \approx 33$ (сложное); $5(8+0,6666 \ldots)$ $\approx 43 ; 5(10+0,6666 \ldots) \approx 53 ; 5(12+0,6666 \ldots) \approx 63 ;$ (сложное, условно « $\mathbf{S} ; ; 5(14+0,6666 \ldots)$ $\approx 73 ; 5(16+0,6666 \ldots) \approx 83 ; 5(18+0.6666 \ldots) \approx 93(\in » \mathrm{~S} \gg$ - принадлежит к сложным). $5(20+0,6666 \ldots) \approx 103 ; 5(22+0,6666 \ldots) \approx 133 ; 5(24+0,6666 \ldots) \approx 123(\mathrm{~S}) ; 5(26+0,6666 \ldots$ )$\approx 133 ;(\mathrm{S}) ; 5(28+0,6666 \ldots) \approx 143 ;(\mathrm{S}) .5(30+0,6666 \ldots) \approx 153 ;(\mathrm{S}) .5(32+0,6666 \ldots)=163$; $5(34+0,6666 \ldots) \approx 173 ; 5(36+0,6666 \ldots) \approx 183 ;(S) .5(38+0,6666 \ldots) \approx 193$; $5(40+0,6666 \ldots) \approx 203 ;(\mathrm{S}) .5(42+0,6666 \ldots) \approx 213 ;(\mathrm{S}) .5(44+0,6666 \ldots) \approx 223$; $5(46+0,6666 \ldots) \approx 233 ; 5(48+0,6666 \ldots) \approx 243 ;(\mathrm{S}) .5(50+0,6666 \ldots) \approx 253$; $5(52+0.6666 \ldots) \approx 263 ; 5(54+0,6666 \ldots) \approx 273 ;(S) .5(56+0,6666 \ldots) \approx 283 ; 5(58+$ $0,6666 \ldots) \approx 293 ; 5(60+0,6666 \ldots) \approx 303 ;(\mathrm{S}) .5(62+0,6666 \ldots) \approx 313 ; 5(64+0,6666 \ldots) \approx$ $323 ; 5(66+0,6666 \ldots) \approx 333 ;(\mathrm{S}), 5(68+0,6666 \ldots) \approx 343 ; 5(70+0,6666 \ldots) \approx 353$; $5(72+0,6666 \ldots) \approx 363 ; 5(74+0,6666 \ldots) \approx 373 ; 5(76+0,6666 \ldots) \approx 383 ; 5(78+0,6666 \ldots) \approx$

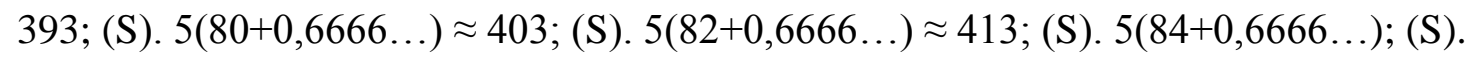
$5(86+0,6666 \ldots) \approx 433 ; 5(88+0,6666 \ldots) \approx 443 ; 5(90+0,6666 \ldots) \approx 453 ;(\mathrm{S})$. $5(92+0,6666 \ldots) \approx 463 ; 5(94+0,6666 \ldots) \approx 473 ;(\mathrm{S}) .5(96+0,6666 \ldots) \approx 483 ;(\mathrm{S})$.

В функции $\operatorname{Pr}=5(\mathrm{Y}+0,6666 \ldots)$ при $\mathrm{Y}=6 ; 12 ; 18 ; 24 ; 30 ; 36 ; 42 ; 48 ; 54 ; 60 ; 66 ; 72 ; 78$; 84; 90; 96 (и других значениях «Ү»), - вместо ожидаемых простых чисел образуются сложные, то есть это смешанная функция числообразования... сложные нечетные числа, в зависимости от числового корня, их образующего, условно можно разделить 
на много групп (и подгрупп). Основные группы с минимальными корнями это: S»3» (корнем является «3», умноженное на нечетное определенное число. Включает подгруппу $\mathrm{S»33»} \mathrm{(образование} \mathrm{сложных} \mathrm{чисел} \mathrm{рассматривается} \mathrm{от} \mathrm{«33»...} \mathrm{далее}$ следуют группы $\mathrm{S} » s »($ или группа $\mathrm{A}$ - группа); $\mathrm{S} » 7 » ; \mathrm{S} » 11 » ; \mathrm{S}$ »13» и другие, о которых будет указано.

При указанных значениях «Ү» от 6 до 96 образуются сложные числа подгруппы $\mathrm{S} » 33 »=33+30 \mathrm{xn}$ (входит в группу $\mathrm{S} » 3 »)$. Все эти числа делятся на «3». 33:3=11 $\in \mathrm{Pr}$; $63: 3=21(\mathrm{~S}) ; 93: 3=31 \in \operatorname{Pr} ; 123: 3=41 \in \operatorname{Pr} ; 153: 3=51 \in \mathrm{S} » 3 » ; 183: 3=61 \in \operatorname{Pr} ; 213: 3=71 \in \operatorname{Pr}$; 243:3=81(S); 273:3=91(S); 303:3=101 $\in \operatorname{Pr} ; 333: 3=111(\mathrm{~S}) ; 363: 3=121(\mathrm{~S}) ; 393: 3=131(\mathrm{Pr})$; 423:3=141(S); 453:3=151(Pr).

Деление на «3» чисел $\mathrm{S}$ «33» образует простые и сложные числа: квадраты простых чисел $\left(121=11^{2}\right)$; сложные $S \ll 7 »-$ группы: $S \ll 7 »=7+14 x n:(91=7+14 x 6)$; $231=7+14 x 16 \ldots$ Числа при $\mathrm{Y}=6 \mathrm{xn}(\mathrm{n} \rightarrow \infty)$, цельноделимые на «3», в функции $\operatorname{Pr}=5(\mathrm{Y}+0,6666 \ldots)$ для нахождения простых чисел исключаются, как и другие сложные...

Рассмотрим далее способы идентификации и исключения сложных чисел для определения простых чисел... Одним из способов определения простых чисел есть идентификация через группу сложных $\mathrm{S} \ll 7 »=7+14 \mathrm{xn} ; \mathrm{n}=0 \rightarrow 7 \ldots$ В группе образуются числа: $21(\mathrm{n}=1) ; 35(\mathrm{n}=2) ; 49\left(\mathrm{n}=3 ; 49=7^{2}\right) .63 ; 77 ; 91 ; 105 ; 119 ; 133 ; 147 ; 161 ; 175 ; 189$; $203 ; 217 ; 231 ; 245 ; 259 ; 273 ; 287 ; 301 ; 315 ; 329 \ldots$

Разделим значения образуемых чисел в группе на «7», получим: $1 ; 3 ; 5 ; 7 ; 9 ; 11 ; 13$; $\underline{15} ; 17 ; 19 ; \underline{21} ; 23 ; \underline{25} ; 27 ; 29 ; 31 ; \underline{33} ; \underline{35} ; 37 ; 39 ; \ldots$ то есть ряд всех нечетных чисел функции $\mathrm{Y}=3+2 \mathrm{xn}(\mathrm{n}=0 \rightarrow 3 ; \mathrm{n}=1 \rightarrow 5)$; «1» образуется при $\mathrm{n}=-1$, поэтому не учитывается... Сложные подчеркнуты.

Таким образом, в функции $S$ «3»=9+6xn, - образуются только сложные нечетные числа...

Если значение функции (S «7»=7+14xn) - разделить на «7» и исключить из множества образованных чисел значения чисел функции $S \ll 3 »=9+6 \mathrm{xn}$, получим огромное множество простых чисел до бесконечности. При этом надо исключить и все сложные функции $S \ll 7 »=7+14 \times n$ (n> 0).

Вывод: $\left\{\operatorname{Pr} \rightarrow \infty=\left\{\rightarrow \infty \frac{7+14 x n}{7}-\{\rightarrow \infty 7+14 \times n,(n>0)-\{\rightarrow 9+6 n\right.\right.$;

Или коротко: : $\left\{\boldsymbol{P r} \rightarrow \infty=\left\{\rightarrow \infty \frac{S \text { "7" }}{7}-\{\rightarrow \infty S\right.\right.$ "7" - $\{\rightarrow \infty S$ "3". Это первый вариант определения простых. 
Символ $\{\rightarrow \infty \mathrm{X}$ - означает , что множество «Х» стремится к бесконечности...

Рассмотрим деление и образование результата для значения функции $\mathrm{S} \ll 3 » .9: 3=3$; $15: 3=5 ; 21: 3=7 ; \ldots .1 ; 3 ; 5 ; 7 \in \operatorname{Pr}$ (простые числа). 27:3=9; 33:3=11; 39:3=13; 45:3=15; $51: 3=17 ; 57: 3=19 ; 63: 3=21 ; 69: 3=23 ; 75: 3=25 ; 81: 3=27 ; 87: 3=29 ; 93: 3=31 ; 99: 3=33$; $105: 3=35 ; 111: 3=37 ; 117: 3=39 ; .11 ; 13 ; 17 ; 19 ; 23 ; 29 ; 31 ; 37$, - простые числа; 15; 45; 25; 75; 105, - сложные одновременно двух групп - S «3» и $\mathrm{S} « 5 »$ (А - группа.) 33; 99 $\in \mathrm{S}$ «3» и $\mathrm{Z}$ - гомогенной группе (такие числа во всех значениях одинаковы. $K$ примеру: 1111; 333; 5555; 7777). Всегда сложные, без остатка, делятся на «11».

Числа, образуемые одновременно в двух группах, называются объединяющими или

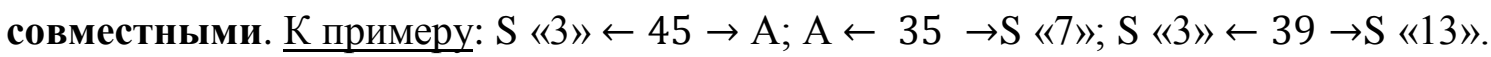
Учитывая, что при делении на «3» чисел $\mathrm{S} « 3 »-$ группы образуется множество простых чисел, их можно определять так:

$\left\{\rightarrow \infty \operatorname{Pr}\right.$ или $\left\{\operatorname{Pr} \rightarrow \infty=\left\{\frac{S " 3 "}{3} \rightarrow \infty-\{\mathrm{S} \ll 3 » \rightarrow \infty-\mathrm{A}-\mathrm{Z}\right.\right.$ (определение А и Z групп не представляет проблемы).

Это второй способ определения простых чисел до бесконечности. Рассмотрим деление сложных $\mathrm{S}$ «3» - группы по возрастающей...

$123: 3=41 ; 129: 3=43 ; 135: 3=45 ; 141: 3=47 ; 147: 3=49 ; 153: 3=51 ; 159: 3=53 ; 165: 3=55$; $171: 3=57.41 ; 43 ; 53 \in \operatorname{Pr} ; 49=7^{2} \in S \ll 7 » ; 45 ; 51 ; 57 \in \mathrm{S} \ll 3 »$. Видно, что в значении (S «3»:3) кроме простых чисел и сложных $S \ll 3 »$ образовалось и сложное $S \ll 7 », 7^{2}=49$. Квадраты простых чисел образуются и в больших значениях (S «3»:3) до

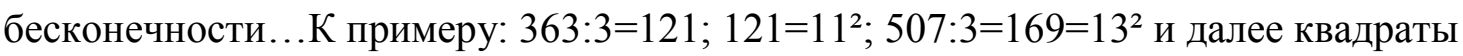
всех простых чисел, до бесконечности. В значениях ( $\mathrm{S} « 3 »: 3)$ образуются сложные нечетные числа больших порядков, по возрастающей. К примеру: 663:3=221; $221=13 \times 7 ; \in \mathrm{S} « 13 » \ldots$ От числа $187=11 \times 17$ (сложное $\mathrm{S} » 11 ») ; 561: 3=187,-$ можно составить закономерность: $\quad \mathrm{Y}=\mathrm{X} \pm 22 \mathrm{xn} \rightarrow \mathrm{S} \ll 11 »$ (образуются сложные, делимые на «11»). При уменьшении на «22» образуются числа: 187-22=165; далее образуются $143 ; 121\left(11^{2}\right) ; 99 ; 77 ; 55 ; 33 ; 11$. При увеличении на «22» от «187» образуются числа: $187+22=209 ; 231 ; 253 \in \operatorname{Pr} ; 275 ; 297 ; 319 \in \operatorname{Pr} ; 341 ; 363 ; 385 ; 407 \in \operatorname{Pr}$; $413 ; 435 ; 457 \in \operatorname{Pr} .$. В группе $\mathrm{S} « 11 »$ образуются объединяющие числа: $\mathrm{A} \leftarrow 55 \rightarrow S$ «11»; А $\leftarrow 165 \rightarrow S « 11 » ;$ образуются и простые числа. Значит, функция $\mathbf{Y = 1 1 + 2 2 x n}$ есть функцией смешанных чисел... Tаким образом, в функции $\mathrm{S}$ « $3 / 3 »=(9+6 \mathrm{xn}): 3=3+2 \mathrm{n}(\mathrm{n} \rightarrow \infty)$ образуются простые числа методом исключения из образованных чисел значений функции $\mathrm{Y}=9+6 \mathrm{xn}$ (сложные), $\mathrm{A}-$ группы ( $\mathrm{S}$ «»)), Z группы (гомогенные числа), а также новые значения, не образованные в функции $\mathrm{Y}=7+14 \mathrm{xn}$ и $\mathrm{Y}=9+6 \mathrm{xn}$.

Не определяются таким способом такие простые, как 253; 319; 407; 457 и другие. Но он есть более полный, чем второй, учитывая исключение D - чисел (числа, не 
образованные как сложные в группах $\mathrm{S}$ «3» и $\mathrm{S}$ «7»; A и Z, образовавшиеся в $\mathrm{Y}=3+2 \mathrm{xn})$.

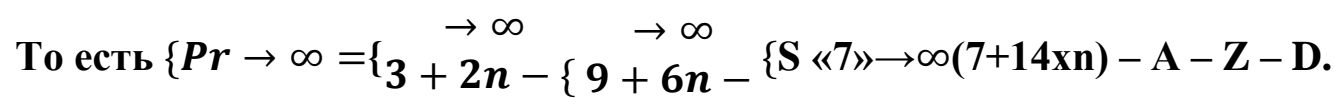

Ряд всех нечетных чисел, начиная с «1» обозначим $\mathbf{Q}_{\mathbf{1}}$; от значения первого сложного числа «9»- $\mathbf{Q}_{2}$. В ряду $\mathrm{Q}_{1}$ значения всех чисел вычисляются по формуле $\mathrm{X}=2 \mathrm{n}_{1}-1$; в ряду $\mathrm{Q}_{2}$ по формуле $\mathrm{X}=7+2 \mathrm{xn}_{2} ;\left(\mathrm{n}_{2}=1 \rightarrow 9 ; \mathrm{n}_{2}=2 \rightarrow 11 ; \mathrm{n}_{2}=3 \rightarrow 13\right.$; $\mathrm{n}_{2}=4 \rightarrow 15 ; \mathrm{n}_{2}=5 \rightarrow 17 ; \mathrm{n}_{2}=6 \rightarrow 19 ; \mathrm{n}_{2}=7 \rightarrow 21 ; \mathrm{n}_{2}=8 \rightarrow 23$ и далее до $\left.\infty\right)$.

Значения «X» на «+8» больше в функции $\mathrm{X}=7+2 \mathrm{xn}_{2}$, чем в функции $\mathrm{X}=2 \mathrm{n}_{1}-1$, при $\mathrm{n}_{2}=\mathrm{n}_{1}$. В функции $\mathrm{Q}_{2}$, начиная с «11», образуется множество простых чисел с промежуточными сложными , увеличиваясь от «11» на «+2xn» значений...

Рассмотрим образование квадратов нечетных чисел в функции $\mathrm{X}=7+2 \mathrm{xn}_{2}, \mathrm{c}$ «11»... $\mathrm{X}=7+2 \mathrm{xn}_{2}=(11+2 \mathrm{xn})^{2} ; 7+2 \mathrm{xn}_{2}=121+44 \mathrm{xn}+4 \mathrm{xn}^{2} ; 2 \mathrm{n}_{2}=121+44 \mathrm{xn}+4 \mathrm{n}^{2}-7$; $\mathrm{n}_{2}=57+22 \mathrm{xn}+2 \mathrm{xn}^{2}$; заменим $\mathrm{n} 2$ на «Y».. Y=57+22xn+2xn ${ }^{2}$. При $\mathrm{n}=1 \rightarrow 57+22+2=57+24=81.81=9^{2}=3^{4} \ldots 3 \in \operatorname{Pr} \ldots \ll 57 »-$ му порядку в ряду $\mathrm{Q}_{2}$ соответствует $121=11^{2} ; 11 \in \operatorname{Pr} . .24$-му порядку в $\mathrm{Q}_{2}$ соответствует сложное А-группы «55», - (всем n порядкам в функции квадратов нечетных, с окончанием на ....4, отвечают сложные А-группы. 81-му порядку отвечает $169=13^{2} ; 13 \in \operatorname{Pr}(81 \rightarrow 169)$. Значения $\mathrm{Y}=57+22 \mathrm{xn}+2 \mathrm{n}^{2}$ и $\mathrm{Y}_{1}=22 \mathrm{n}+2 \mathrm{n}^{2}$, - определяют $\mathrm{n}-$ порядки сложных чисел в функции $\mathrm{Q}_{2}=7+2 \mathrm{xn}_{2} \ldots \mathrm{n}-$ порядки в функции квадратов также с окончанием на «...9 9 », как и «....4», - образуют в $\mathrm{Q}_{2}$ числа $\mathrm{A}$ - группы. При $\mathrm{n}=2 \rightarrow 57+44+8=57+52=109 ; \mathrm{n}_{2}=52 \rightarrow 111 \in S$ "3"; $109 \rightarrow 325 \in \mathrm{A} ; 109 \in \operatorname{Pr} ;$ при $\mathrm{n}=3 \rightarrow 57+66+18=57+84=141 ; \mathrm{n}_{2}=84 \rightarrow 7+2 \times 84=175 \in \mathrm{A} ; \mathrm{n}_{2}=175 \rightarrow 357 \in \in \mathrm{S} \ll 3 » ; \in \mathrm{S} \ll 7 »$ (совместное число). $\mathbf{S} « \mathbf{3} » \leftarrow \mathbf{3 5 7} \rightarrow \mathbf{S} « 7 » \ldots \mathrm{n}_{2}=141 \rightarrow 289=17^{2}(17 \in \mathrm{Pr})$

$\mathrm{n}_{2}=289 \rightarrow 7+2 \times 289=7+578=585 \in \mathrm{A}$; $\mathrm{n}=4 \rightarrow 57+22 \times 4+2 \times 16=57+120=177 \ldots \mathrm{n}_{2}=120 \rightarrow 7+240=247(247: 13=19)$; $\mathrm{n}_{2}=177 \rightarrow 361=19^{2} ; \mathrm{n}_{2}=361 \rightarrow 729=27^{2}$.

$\mathrm{n}_{2}=729 \rightarrow 1465 \in \mathrm{A} ; \mathrm{n}_{2}=1465 \rightarrow 2937 \in \mathrm{S} \ll 3 »(2937: 3=979) ; \mathrm{n}=5$ $\rightarrow 57+110+50=57+160=217 ; \mathrm{n}_{2}=160 \rightarrow 7+2 \times 160=327 \in \mathrm{S} \mathrm{S} \ll 3 » . \mathrm{n}_{2}=217 \rightarrow 441=21^{2}$; $\mathrm{n}=6 \rightarrow 57+132+72=57+204=261 ; \mathrm{n}_{2}=204 \rightarrow 415 \in \mathrm{A} ; \mathrm{n}_{2}=261 \rightarrow 529=23^{2} ; 23 \in$ $\operatorname{Pr} ; \mathrm{n}=7 \rightarrow 57+154+98=57+252=309 ; \mathrm{n}_{2}=252 \rightarrow 511 \in S \ll 7 \gg(511: 7=73) ; \mathrm{n}_{2}=309 \rightarrow 625=25^{2} \in$ А... Функция порядков сложных значений $\mathrm{Y}=57+22 \mathrm{xn}+2 \mathrm{xn}^{2}$, - позволяет определить $\mathrm{n}$ - порядки сложных чисел в функции $Q_{2}=7+2 \mathrm{xn}_{2} \ldots$

Существует закономерность: половина значения квадратов нечетных чисел с окончанием «....1,» округленных до целых значений, чаще есть простые числа... 
$81: 2=40,5 \approx 41 \in \operatorname{Pr} ; 121: 2=60,5 \approx 61 \in \operatorname{Pr} ; 441: 2=220,5 \approx 221=11^{2}$ ( или квадраты, четные степени простых чисел, $\operatorname{Pr}^{\mathrm{n}},{ }^{\mathrm{n}}-$ четное число).

Учитывая функцию образования порядков сложных чисел, можно расширить

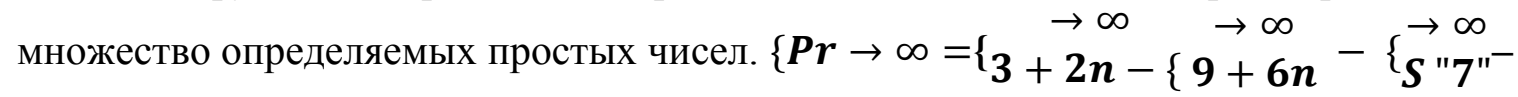
$A-Z-D-\left(\right.$ сложные в $Q_{2}=7+2 x_{2}$, где $\left.n_{2}=57+22 x n+2 x^{2} ; n_{2}=22 x n+2 n^{2}\right) \ldots$ Частично простые числа определяются делением, половиной значения квадратов нечетных.

Образование простых чисел в группе простых

$\operatorname{Pr} \ll 13 »=13+10 \times n$ $(\mathbf{n}=\mathbf{0} \rightarrow \mathbf{1 3} ; \mathbf{n} \rightarrow \infty)$. Интервал между образуемыми ближайшими числами есть «10»: 13, $23 ; \underline{33} ; 43 ; 53 ; 63 ; 73 ; 83 ; \underline{93} ; 103 ; 113 ; \underline{123} ; 133 ; \underline{143} ;(143: 11=13) ; 153 ; 163$;

$173 \ldots$ (сложные подчеркнуты)... В данной группе образуются и сложные подгруппы $\mathrm{S} « 33 »=33+30 \mathrm{xn}, \in S$ "3"(входит в группу сложных $S$ "3)...

В функции $\operatorname{Pr} « 13 »$ образуются такие же числа, как и в функции $\operatorname{Pr}=\mathbf{5}(\mathbf{Y}+\mathbf{0 , 6 6 6 6 . . . )})$ Значит, $5(\mathrm{Y}+0,6666 \ldots)=13+10 \mathrm{xn}$ (но в функции $5(\mathrm{Y}+0,6666 \ldots)$ простых других значений образуется больше. Это числа: $5 ; 11 ; 17 ; 23 ; 29 ; \underline{35} ; 41 ; 47 ; 53 ; 59 ; \underline{65} ; 71 ; \underline{77}$; $83 ; 89 ; \underline{95} ; 101 ; 107 ; 113 ; \underline{119} ; \underline{125 ; 131, \ldots+6 x n . . . ~ П о д ч е р к н у т ы ~ с л о ж н ы е ~ А ~-~ г р у п п ы, ~}$ $\mathrm{Z}$ - группы (77); S «7» (119)... Далее идут: 137; 143(сложное, 143:11=13) 149; 155; 161; $\in$ S "7"; 167 ; 173; 179; 185; 191; 197; 203; $209 \in S$ "11"; 215; 221; (112; $221=13 \times 17$; сложное); 227; 233,... Аналогично можно определить простые числа от «7» в функции $\mathbf{P r}=\mathbf{7 + 6 x n}$, где «7» соответствует n= 0. Это числа: 7; 13; 19; 25; 31; 37; $43 ; \underline{49} ; \underline{55} ; 61 ; 67 ; 73 ; 79 ; \underline{85} ; \underline{91} ; 97 ; 103 ; 109 ; \underline{115} ; \underline{121} ; 127 ; \underline{133} ; 139 ; \underline{145} ; 151 ; 157$;

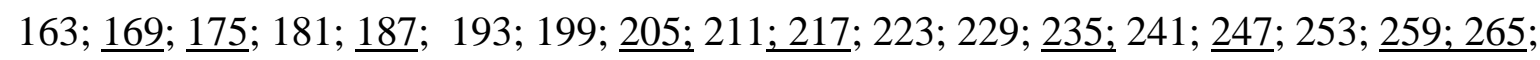
$271 ; 277 ; 283 ; \underline{289}, \ldots$ (сложные подчеркнуты)...

В функции $\operatorname{Pr}$ «7» образуются и сложные числа, в частности, квадраты простых чисел: $121=11^{2} ; 169=13^{2} ; 289=17^{2} \ldots$ Рассмотрим, квадраты каких чисел образуются в функции $\operatorname{Pr} \ll 7 »=7+6 x n$ n $\rightarrow \infty$.

Применим простые и сложные нечетные числа для получения их квадратов...

Квадраты простых чисел: $23^{2}=529 ; 31^{2}=961 ; 29^{2}=841 ; 37^{2}=1369 ; 41^{2}=1681 ; 43^{2}=1849$; $47^{2}=2209 ; 53^{2}=2809 ; 59^{2}=3841 ; 61^{2}=3721 ; 67^{2}=4489 \ldots$

Рассмотрим их образование в функции $\operatorname{Pr} « 7 »=7+6 x n . . .7+6 \mathrm{n}=529 ; \mathrm{n}=87 ; \operatorname{Pr} « 7 »=961$; $\mathrm{n}=159 ; \quad \operatorname{Pr} \ll 7 »=841 ; \mathrm{n}=139 ; \operatorname{Pr} \ll 7 »=1369 ; \mathrm{n}=227 ; \operatorname{Pr} \ll 7 »=1681 ; \mathrm{n}=279 ; \operatorname{Pr}$ $\langle 4 »=1849 \rightarrow \mathrm{n}=307 ; \operatorname{Pr}\langle 7 »=2209 \rightarrow \mathrm{n}=367 ; \operatorname{Pr}\langle 4 »=2809 \rightarrow \mathrm{n}=467 ; \operatorname{Pr}\langle 7 »=3481 \rightarrow \mathrm{n} 579 ; \operatorname{Pr}$ $« 7 »=3721 \rightarrow \mathrm{n}=619 ; \operatorname{Pr} \ll 7 »=4489 \rightarrow \mathrm{n}=747 \ldots$

Вывод: образуются целые n - значения (порядки), значит, в функции Pr «7»= 7+6xn n $\rightarrow \infty$, квадраты простых чисел образуются... Применим сложные нечетные 
числа для образования квадратов...21 $21^{2}=441 ; 27^{2}=729 ; 25^{2}=625 ; 33^{2}=1089 ; 35^{2}=1225$; $39^{2}=1521 ; 45^{2}=2025 ; 49^{2}=2401 ; 51^{2}=2601 ; 55^{2}=3025 ; 57^{2}=3249 ; 63^{2}=3969 ; 65^{2}=4225 \ldots$

Определим их $\mathrm{n}-$ значения в функции $\operatorname{Pr} « 7 » . \operatorname{Pr} « 7 »=7+6 \mathrm{xn}=21^{2}=441 ; \mathrm{n}=72,3333 \ldots$ Pr $\langle 7 »=625 \rightarrow \mathrm{n}=103 ; \operatorname{Pr}\langle 7 »=729 \rightarrow \mathrm{n}=120,3333 \ldots ; \operatorname{Pr}\langle 7 »=1089 \rightarrow \mathrm{n}=180,3333 \ldots \operatorname{Pr} \ll 7 »=$ $1225 \rightarrow \mathrm{n}=203 ; \quad \operatorname{Pr} \ll 7 »=1521 \rightarrow \mathrm{n}=252,3333 \ldots ; \operatorname{Pr} \ll 7 »=2401 \rightarrow \mathrm{n}=339 ;\left(2401=49^{2}=7^{4}\right)$; $\operatorname{Pr} \ll 7 »=2601 \rightarrow \mathrm{n}=432,3333 \ldots ; \quad \operatorname{Pr} \ll 7 »=3025 \rightarrow \mathrm{n}=503 ; \operatorname{Pr}$ $\ll 7 »=3249 \rightarrow \mathrm{n}=540,3333 \ldots ; \operatorname{Pr} \ll 7 »=3969 \rightarrow \mathrm{n}=660,3333 \ldots ; \operatorname{Pr} \ll 7 »=4225 \rightarrow \mathrm{n}=703 \ldots$

Видно, что все $\mathrm{n}$ - порядки с окончанием «...3», - в функции $\operatorname{Pr} « 7 »$ образуют сложные A - группы. На примере $\operatorname{Pr} « 7 »=2401 \rightarrow \mathrm{n}=339 ;\left(2401=49^{2}=7^{4}\right)$ видно, что целые n - порядки квадратов сложных чисел в функции Pr «7»=7+6xn (смешанной) образуются в том случае, если само сложное число образовано минимальным значением, как квадратом простого $\left(49=7^{2}\right)$; то есть целый n порядок возможен при значении $\operatorname{Pr}$ «7», как четной степени простого числа. $\left(2401=49^{2}=7^{4}\right) \ldots$

Первым этапом определения простых чисел является исключение сложных А -

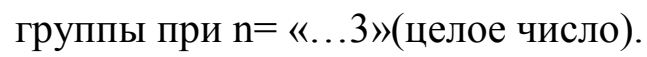

Вторым этапом есть извлечение корней квадратных из образуемых в функции $\operatorname{Pr}$ “7” чисел, от меньших значений к большим...целые числа получатся при извлечении корней квадратных.

Корней квадратных из чисел, образованных возведением простых в степени: 2; 4; 6; $8 ; 10 ; 12 ; 14 ; 16 \ldots$ - в четную $2 \mathrm{xn}-$ степень. Значит, $\operatorname{Pr}=\sqrt[2 n]{\mathrm{Y}}=\mathbf{X}$ - целое число... Числа, образовавшиеся с остатком при получении $\sqrt[2 n]{S}$, - говорят о том, что в значении $\mathbf{S}$ находится нечетная степень простого числа... При небольших относительно Y - значениях определяются корни, простые числа, образующие сложные возведением простых в степени $2 \mathrm{xn} . .$.

Правило проверки числа, полученного как корень квадратный из числа «Ү», - к принадлежности к простым числам. Число «Х», как предполагаемое Рт (простое), следует проверить, как «Ү» в функции $\mathrm{Y}=7+6 \mathrm{xn} . .$. Если образуется целый порядок «n», тогда число или простое в любой степени (сложное), то есть из «Ү» надо также извлечь корень квадратный (для уверенности, что значение есть простым)... Числа «Y», не образованные как степени квадратные, - могут образовываться в «Рr», как нечетные степени простых.

\section{Поэтому простыми числами есть те, из которых в данной функции}

\section{1. Извлекается корень с остатком.}

2. В функции $\mathrm{Y}=7+6 \mathrm{xn}$, - образуется целый «n» порядок. $\oint \operatorname{Pr} \rightarrow \sqrt{\operatorname{Pr}}=\mathrm{X}, \ldots ; \operatorname{Pr}=$ $7+6 \mathrm{xn}, \mathrm{n}-$ целое. Данная закономерность проявляется для чисел, образуемых в 
функции $\operatorname{Pr} « 7 »=7+6 x n$ (n - порядки, равные 7xn, где $\mathrm{n}$ - четное число, образуют сложные числа).

Для определения множества простых чисел из более крупных $\mathrm{Y}=7+6 \mathrm{xn}$, следует извлекать $\sqrt[4]{\mathrm{Y}} ; \sqrt[6]{\mathrm{Y}} ; \sqrt[8]{\mathrm{Y}}$ и далее по возрастающей, (корни четвертой степени от $100,-$ для исключения сложных; параллельно проверять $\mathrm{n}-$ значения в $\operatorname{Pr}$ «7» значений четных корней... Образование значений четных корней с остатком при «n» целых порядках в Y = 7+6xn, - указывает на простое число в значениях $\mathrm{Pr}=\mathrm{X}=$ $\sqrt[a]{7+6 \times n} 4 ; a-$ четная степень; $X=7+6 x n$ (n - целое число). Примеры: $\mathrm{n}=1 \rightarrow 7$ $=6 \times n=13 ; \sqrt{13}=3,60555 \ldots ; 13 \in \operatorname{Pr} ; \mathrm{n}=2 \rightarrow 7+6 \times 2=19 ; \sqrt{19}=4,358898 \ldots ; 19 \in \operatorname{Pr} ; \mathrm{n}=$ $3 \rightarrow 7+6 \times 3=25 ; \quad \sqrt{25}=5 \in \mathrm{A}$; все $\mathrm{n}-$ порядки с окончанием на «...3» образуют сложные числа в $-\mathrm{Y}=7+6 \mathrm{xn} ; \mathrm{n}=23 \rightarrow 7+6 \times 23=145 \ldots$ образуется $\mathrm{A}-$ группа. $\mathrm{n}=27$ $\rightarrow 7+6 \times 27=169 ; \sqrt{169}=13 ; \mathrm{n}=47 \rightarrow 7+6 \times 47=289 ; \sqrt{289}=17$.

Меньшие значения $\sqrt{\mathrm{Y}}=\mathrm{X}, \ldots$ полученные с остатком в фнкции $\mathrm{Y}=7+6 \mathrm{xn},-$ подтверждают, что значение $\mathrm{Y}_{1}=\mathrm{Y}$, образовавшиеся как корни квадратные из больших значений $\mathrm{Y}_{2} ; \mathrm{Y}_{1}=\sqrt{\mathrm{Y}_{2}},-$ есть простые числа, извлеченные из их квадратов, при целых n-порядках значений $\mathrm{Y}_{2}$ в функции $\mathrm{Y}=7+6 \mathrm{xn}$. Если целому числу $\mathrm{Y}_{1}$ соответствует целый $\mathrm{n}_{2}$-порядок в зависимости $\mathbf{Y}_{\mathbf{1}}=\sqrt[a]{\mathrm{Y}_{2}}$, тогда $\mathrm{Y}_{2}$ - значение четной степени $\mathrm{Y}_{1} \ldots$ Простые числа, большинство их, можно определить по формуле:

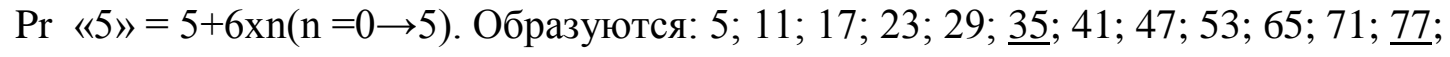
(гомогенное Z число); 83; 89; 95; 101; 107; 113; 119; $125 ; 131 ; 137 ; \underline{143} ; 149 ; \underline{155} ; 161$;

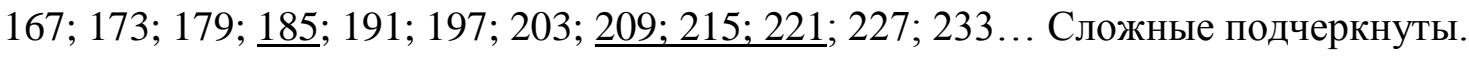

Многие значения не образуемые в $\mathrm{Y}=7+6 \mathrm{xn}$, образуются в функции $\mathrm{Y}=5+6 \mathrm{xn},-17$; $23 ; 41 ; 47$ и другие. Однако в Y = 7+6хn образуются квадраты не образованных простых чисел при целых n-порядках в функции $\operatorname{Pr} « 7 »$. Значит, простые числа из функции $\mathrm{Y}=5+6 \mathrm{xn}$, - подтверждают, что образованные значения $\sqrt{7+6 \mathrm{xn}}=\mathrm{X}-$ целое, $\in \mathrm{Pr}$, если число «Х» входит, образуется функцией $\mathrm{Y}=5+6 \mathrm{xn}$, как $\mathrm{Pr} . . . \mathrm{B}$ функции $Y=7+6 x n$ могут образовываться квадраты сложных трех - и (более) значных чисел, образованные как трех (и более) - значные в функции Y = $5+6 \times n$.

К примеру: $119^{2}=4161 ; \mathrm{Y}=7+6 \mathrm{xn}=14161 ; \mathrm{n}=2359 ; 143^{2}=20449 ; 7+6 \mathrm{n}=20449 ; \mathrm{n}=$ 3407.

Если при целом «n» в функции $\mathrm{Y}=7+6 \mathrm{xn}$, из значения $\mathbf{Y}=\mathbf{X}^{\mathbf{n}}, \mathrm{n}-$ четная степень, не извлекается корень квадратный до получения целого двухзначного $(\sqrt{289}=17$; $\sqrt{361}=19$ ит.д), то квадрат числа, вероятно, образован сложным числом из других функций... К примеру: $\sqrt{143}=11,95826 \ldots ; 143^{2}=20449$, при $n=3407$ в функции $\operatorname{Pr}$ 
«7» или квадрат образован от трехзначного простого числа функции, отличной от Y $=7+6 \times n$.

$137^{2}=18769 ; \mathrm{n}=3127 ; 137 \in \operatorname{Pr} ; \mathrm{n}=21,6666 \ldots 143 \rightarrow \mathrm{n}=22,6666 \ldots \mathbf{n}$ - порядки чисел, образовавших квадраты в значениях функции $Y=7+6 x n$, - как образованных простых и сложных (не квадратичных) чисел в функции $\mathbf{Y}=\mathbf{5 + 6 x n}$. (137ePr; 143 $=11 \times 13)$, в $\mathrm{n}-$ значениях функции $\mathbf{Y}=\mathbf{7 + 6 x n}$, - образуют остаток $0,6666 \ldots$, в отличие от сложных функции $\mathrm{Y}=7+6 \mathrm{xn}$, при которых $\mathrm{n}$ - порядок - целое число... значит, при получении $\mathrm{Y}=\sqrt{7+6 \mathrm{xn}}$, следует проверять $\mathrm{n}-$ порядок образовавшегося числа «Y», для установления происхождения числа в той или другой функции... $\mathbf{n}$ порядки квадратов простых чисел в $Y=7+6 \times n$, образующиеся как целые числа, - основа определения Pr...

Рассмотрим образование квадратов нечетных чисел от «9».

$9^{+16} 25^{+24} 49^{+32} 81^{+40} 121^{+48} 169^{+56} 225^{+64} 289^{+72} 361^{+80} \quad 441^{+88} \quad 529 \ldots$.

Видна закономерность, - интервал между квадратами нечетных чисел увеличивается на «+8». Если точкой отсчета квадратов нечетных чисел принять «9» $\left(3^{2}\right)$, то каждое следующее значение квадрата нечетного числа, назовем Q, можно определить по формуле $\mathbf{Q}=\mathbf{9 + 8 x n}(\mathrm{n}=2 \rightarrow 25 ; \mathrm{n}=5 \rightarrow 49 ; \mathrm{n}=9 \rightarrow 81 ; \mathrm{n}=20 \rightarrow 169)$. В $\mathbf{Q}$ - значениях наблюдается рост $\mathbf{n}-$ порядков: $2^{+3} 5^{+4} 9^{+5} 14^{+6} 20 \ldots$

Если принять $\mathrm{n}_{1}=2 \rightarrow 25 ; \mathrm{n}_{2}=5 \rightarrow 49$, то $\Delta \mathbf{n}=\mathbf{n}_{\mathbf{2}}-\mathbf{n}_{\mathbf{1}}$ (приращение порядка равно: $5-2$ $=3 ; 9-5=4 ;(4-3=1) ; 20-14=6 ;(6-5=1)$. Приращение $(\Delta \mathrm{n})$ порядка при каждом значении $\mathrm{Q}$ увеличивается на «+1»...

Если $\Delta \mathrm{n}=4$,то $\mathrm{n}_{3}=\mathrm{n}_{2}+\Delta \mathrm{n}=5+4=9 \rightarrow 81$.

$\Delta \mathrm{n}=5 \rightarrow 9+5=14 ; \mathrm{n}_{4}=14 ; \Delta \mathrm{n}=6 \rightarrow 6+14=20 ; \mathrm{n}_{5}=20 ; \Delta \mathrm{n}=7 ; \mathrm{n}_{6}=20+7=27 ;$

$\Delta \mathrm{n}=8 \rightarrow 27+8=35 \ldots$

$\Delta \mathrm{n}=9 \rightarrow 35+9=44 ; \Delta \mathrm{n}=10 \rightarrow 44+10=54 ; \Delta \mathrm{n}=11 \rightarrow 54+11=65 ; \Delta \mathrm{n}=12 \rightarrow 65+12=77 ; \Delta \mathrm{n}$ $=13 \rightarrow 77+13=90 ; \Delta \mathrm{n}=14 \rightarrow 90+14=101 ; \Delta \mathrm{n}=15 \rightarrow 101+15=119$. Значит, порядок квадратов определяется: $\mathrm{n}_{2}=\mathrm{n}_{1}+\Delta \mathrm{n}_{2} \cdot\left(\Delta \mathbf{n}_{2}=\Delta \mathbf{n}_{1}+1\right.$; приращение каждого $\mathbf{n}-$ значения большего соседнего квадрата нечетного числа увеличивается на «+1».

Можно составить таблицу «n» - порядков квадратов чисел $\mathrm{Q}$, начиная с $9=3^{2} \ldots$ Значения $\mathrm{n}-$ порядков Q: $\mathrm{n}=0 \rightarrow 9 ; \mathrm{n}=2 \rightarrow 25 ; \mathrm{n}=5 \rightarrow 49 ; \mathrm{n}=9 \rightarrow 81 ; 14 \rightarrow 121 ; 20 \rightarrow 169$; $27 \rightarrow 225 ; 35 \rightarrow 289 ; 44 \rightarrow 361 ; 54 \rightarrow 441 ; 65 \rightarrow 529 ; 77 \rightarrow 625 ; 90 \rightarrow 729 ; 104 \rightarrow 841 ;$ $119 \rightarrow 961 ; 135 \rightarrow 1089 ; 152 \rightarrow 1225 ; 179 \rightarrow 1369 ; 189 \rightarrow 1521 ; 209 \rightarrow 1681 ; 230 \rightarrow 1849$; $252 \rightarrow 2025 ; 275 \rightarrow 2209 ; 299 \rightarrow 2401$. 
n=324 $\rightarrow 2601 \ldots$ n - порядки сложных чисел, цельноделимых на «3»,- образуют квадраты сложных нечетных чисел, цельноделимых на «3»... n=90 $\rightarrow 729=$ $27^{2}(90: 3=30 ; 27: 3=9) ; \mathrm{n}=189 \rightarrow 1521=39^{2}(189: 3=39 ; 39: 3=13)$ $\mathrm{n}=324 \rightarrow 2601=51^{2}(324: 3=108 ; 51: 3=17)$.

Еще раз рассмотрим образование квадратов нечетных чисел от «9»...

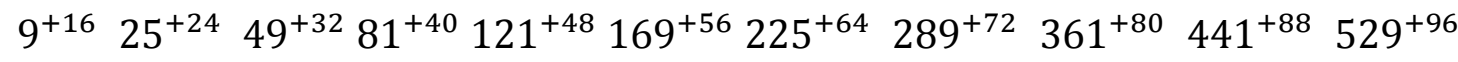
$625^{+104} 729^{\rightarrow \infty}$

$\Delta \mathrm{Q}=104 \rightarrow 729 ; \sqrt{729}=27($ сложное $\mathrm{S} \ll 3 ») ; \Delta \mathrm{Q}=128 \rightarrow 1089 ; \sqrt{1089}=33 \in \mathrm{S} \ll 3 »$.

Увеличение приращения квадрата ближайшего сложного «33» (к 27²) составляет «+24»: $128-104=24$.

От 729 ряд Q следует так: $729^{+112} 841^{+120} 961^{+128} 1089^{+136} 1225 \ldots$

Проверим $\Delta \mathrm{Q}=152 \rightarrow 1521 ; \sqrt{1521}=39 \in \mathrm{S} \ll 3 » ; \Delta \mathrm{Q}=144 \rightarrow 1369 ; \sqrt{1369}=37 ; 1521^{+160}$ $1681(\sqrt{1681}=41)$ От 1681 следуют: $1681^{+168} 1849(\sqrt{1849}=43)^{+176}$

$2025(\sqrt{2025}=45 \in \mathrm{A} \in \mathrm{S} \ll 3 » ; \mathrm{A} \leftarrow 45 \rightarrow \mathrm{S} \ll 3 »$. (число, объединяющее две группы сложных). 176-152=24; 152 $\rightarrow 1521=392 ; 39 \in \mathrm{S} \ll 3 » ;$ от 2025 следуют: $\quad 2025^{+184} 2209$ $(\sqrt{2209}=47)^{+192}-2401\left(\sqrt{2401}=49 ; 49=7^{2}-\text { квадрат простого числа }\right)^{+200} 2601(\sqrt{2601}$ $=51 \in \mathrm{A} \in \mathrm{S} \ll 3 ») \ldots{ }^{+208} 2809\left(\sqrt{2809}=53^{+216} 3025\left((\sqrt{3025}=55 \in \mathrm{A}){ }^{+224}\right.\right.$ $3249(\sqrt{3249}=57 \in S \ll 3 » ; 57: 3=19)$ разница приращений $224-200=24 \ldots 3249^{+232} 3481$ $(\sqrt{3481}=59)^{+240} 3721(\sqrt{3721}=61) 3721^{+248} 3969(\sqrt{3969}=63 \in \in \mathrm{S} \ll 3 » \in \mathrm{S} \ll 33 »)$ Разница приращений: $248-224=24^{+256} 4225 \quad 4489(\sqrt{4489}=67)^{+272} \quad 4761(\sqrt{4761}=$ $69 \in \mathrm{S} « 3 »)$ Разница приращений: 272-248=24) $)^{+280} 5041(\sqrt{5041}=71)^{+288}$ $5329(\sqrt{5329}=73)^{+296}-5625(\sqrt{5625}=75)^{+304} 5929(\sqrt{5929}=77 \in Z)^{\in \mathrm{A}+312}$ $6241(\sqrt{6241}=79)^{+320} 6561\left(\sqrt{6561}=81=9^{2}=27 \times 3 ; \in S \ll 3 »\right) \ldots$

Зная приращение до ближайшего (наименьшего) квадрата сложного нечетного числа,-от «49» до «81»,- «32»,- можно определить все приращения квадратов сложных нечетных чисел и узнать значения этих чисел (для последующего извлечения корней квадратных и исключения их значений из ряда определяемых простых чисел). Приращение квадратов сложных от «81» равны: 32; 56; 80; 104; $128 ; 152 ; 176 ; 200 ; 224 ; 248 ; 272 ; 296 ; 320 ; 344 ; 368 ; 392 ; 416 ; 440 ; 464 ; 488 \ldots$ и далее до бесконечности по формуле: $\underline{\Delta S^{2}=32+24 x X} ; n=0 \rightarrow 81=9^{2}=49+32=7^{2}+32 \ldots n=1 \rightarrow 225$.

Выводы: 
1. n-порядки квадратов сложных нечетных чисел, четные и нечетные, в функции $\mathbf{Q = 9 + 8 n}$, цельноделимые на «3»,- подтверждают, что в значениях $\mathbf{Q}$ образованы квадраты сложных, делимых на «3». Числа этих порядков при определении простых,исключаются...(n=90 $\left.\rightarrow 729=27^{2} ; 27: 3=9 ; n=324 \rightarrow 2601=51^{2} ; 51: 3=17\right) ; \mathrm{Q}=\mathrm{S}^{2}$, при n:3=X - целое,- исключаются...

2.Исключаются числа А-группы (делимые на «5», как сложные)... Исключаются $Z^{2}$ числа, образованные из гомогенной $\mathrm{Z}$ группы...

3.Исключаются сложные нечетные, как корни квадратные, определенные по формуле роста приращений квадратов сложных чисел, от 81: $\Delta S^{2}=32+24 x X$, где

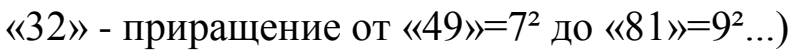

4.Исключаются промежуточные сложные (не квадраты) группы $\mathrm{S}$ «7» (119; 91 и другие (сами не квадраты, но образуют квадраты сложных).

5.Исключаются числа (возможно из других групп), образованные как корни квадратные из квадратов больших порядков; и значений в интервалах, образуемых функцией $\Delta \mathbf{S}^{2}=\mathbf{3 2}+\mathbf{2 4 x} \mathbf{X}, \mathbf{X} \neq \mathbf{0}, \mathbf{X} \rightarrow \infty \ldots$ Идентфикация производится использованием функций $\mathrm{Y}=5+6 \mathrm{xn},(\mathrm{n} \rightarrow \infty)$ и $\mathrm{Y}=5+7 \mathrm{xn}(\mathrm{n} \rightarrow \infty) \ldots$. Вероятно, простые числа, как промежуточные в функции $\mathrm{Y}=9+8 \times \mathrm{xn}(\mathrm{n} \rightarrow \infty),-$ должны в $\operatorname{Pr}$ «5» и $\quad \operatorname{Pr}$ «7» образовывать целые $\mathrm{n}$ - порядки...проверим это: $91=7+6 \mathrm{xn} ; \mathrm{n}=14 ; 91=5+6 \mathrm{xn} ; \mathrm{n}=14,3333 \ldots ; 119=7+6 \mathrm{xn} ; \mathrm{n}=18,6666 \ldots ; 119=5+6 \mathrm{xn}$; $n=114: 6=19 ; 5+6 x n=35 ; n=5 ; 7+6 x n=35 ; n=4,6666 \ldots$ Видно, что ни одно промежуточное значение $\sqrt{\mathrm{X}^{2}}=\sqrt{9+8 n}$ (при определенных «n»), - не образовало целые n - порядки в обеих функциях...Промежуточные сложные, как 91; 119; исключаются как $\mathrm{Y}=\sqrt{9+8 \mathrm{xn}}$, при 9+8xn=91; 119 $\rightarrow \mathrm{n}=1034 ; 1769 \ldots$ Учитывая, что промежуточные (между квадратами сложных) приращения квадратов не четных чисел увеличиваются в каждом значении на «+8» и известны значения приращений квадратов сложных не четных чисел: $\Delta \mathrm{S}^{2}=32+24 \mathrm{X} X$, - можно узнать значения промежуточных приращений, обозначим как $\Delta \mathbf{P r}$... Рассмотрим интервалы [32; 56] ; [56; 80]. В первом интервале образуются $\Delta \operatorname{Pr}: 32+8=40 ; 40+8=48$;

$\Delta \mathrm{Pr}=40 \rightarrow 81+40=121=11^{2} ; 11 \in \operatorname{Pr} ; \Delta \operatorname{Pr}=48 \rightarrow 121+48=169=13^{2} ; 13 \in \operatorname{Pr} ; 169+56=225=15^{2} \in$ А; во втором интервале: $\Delta \mathrm{Pr}=56+8=64 ; \rightarrow 225+64=289=17^{2} ; 17 \in \mathrm{Pr}$; $\Delta \mathrm{Pr}=64+8=72 \rightarrow 289+72=361=19^{2} ; \quad 19 \in \operatorname{Pr}$. Тогда верно: $\operatorname{Pr}^{2}{ }_{1}=\mathrm{S}^{2}+\Delta \operatorname{Pr}^{2}{ }_{1} ; \operatorname{Pr}^{2}{ }_{2}=$

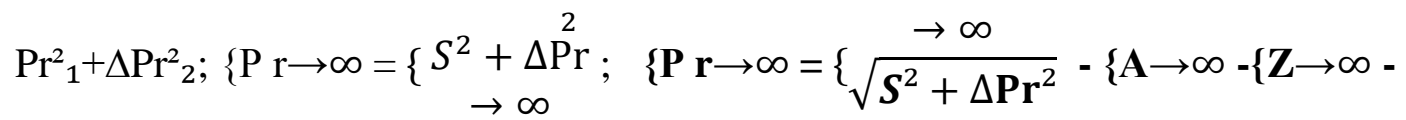
$\left\{\sqrt{S^{2}[\downarrow]} \rightarrow \infty\right.$ (промежуточные сложные, $\sqrt{S^{2}[\downarrow]}=\sqrt{9+8 n} \nleftarrow\left\{\begin{array}{l}\operatorname{Pr} " 5 " \\ \operatorname{Pr} " 7 "\end{array}\right.$

Обозначения: $[\downarrow]$ - означает значения внутри интервалов; $\{\rightarrow \infty$ - множество, 
стремящееся до бесконечности; $\nleftarrow\left\{\begin{array}{l}\operatorname{Pr} " 5 " \\ \operatorname{Pr} " 7 "\end{array}\right.$ квадратные, из значений внутри интервалов, - не образуются совместно в функциях Pr «5»=5+6xn и Pr «7»=7+6xn, - в какой - либо функции образуется $\mathrm{n}$ - порядок с остатком; как корни квадратные промежуточные сложные определяются в $\mathrm{Y}=9+8 \mathrm{xn}$ при больших порядках... От «81» квадрат сложного числа можно определить так: $\mathbf{Q}=\mathbf{8 1}+(32+24 \times \mathbf{X})+\sum \Delta S^{2}[\downarrow]$, где $\sum \Delta S^{2}[\downarrow]$ - сумма приращений промежуточных квадратов нечетных, $S^{2}$ - предполагаемый квадрат простого числа (но, вероятно, $\mathbf{S}$ - сложные возможны)... X=1 $\rightarrow 81+(32+24)+40+48=225 ; \sqrt{225}=15 ; \mathrm{A} \leftarrow$ $15 \rightarrow S " 3 "$.

$\mathrm{X}=2 \rightarrow 81+40+48+56+64+72+80=441 ;(\sqrt{441}=21 \in \mathrm{S} « 3 " . \ll 80 »$ образуется как $32+24 \times 2=80$. Находим промежуточные числа между $\Delta \ll 81 »=32$ и 80,- (+8) -40; 48; 56; 64» 72; суммируем. Промежуточные сложные, как 91; 119; $\in \mathrm{S} « 7 "$; и другие, образованные при меньших $\mathrm{n}$ - порядках в функции $\mathrm{Y}=9+8 \mathrm{xn},-$ при приращениях, которые по предположению, должны были образовать простые числа, исключаются как $\sqrt{\boldsymbol{S}^{2}[\downarrow]}$ (промежуточные сложные), при появлении их при больших $\mathrm{n}-$ порядках в функции $\mathrm{Y}=9+8 \mathrm{xn}$, как образующих квадраты сложных чисел, образующихся при приращениях $\Delta \mathrm{S}^{2}=32+24 \mathrm{x} \mathrm{X}$, что отвечает интервалам приращений: [32; 56; ]; [56; 80; ]; [80; 104; ]; [104; 128; ]; [128; 152; ]; [152; 176; ] и далее, до $\infty$, с ростом «+24хX.». Значит, простые числа - значения, если $P \mathbf{r}=\sqrt{\mathbf{S}^{2}+\Delta \mathbf{P r}^{2}} \rightarrow X, \ldots$ (с остатком; с исключением $\mathrm{A} ; \mathrm{Z}$; и $\boldsymbol{S}[\downarrow]$ (промежуточных сложных). Если существует предполагаемая закономерность образования $\mathrm{n}$ - порядков простых чисел в функции $\quad \operatorname{Pr}=9+8 x n$, изложено ранее), - приращение $\Delta \mathrm{n}-$ порядка при каждом значении числа увеличивается на $«+1 »(2 \stackrel{+3}{\rightarrow} 5 ; 5 \stackrel{+4}{\rightarrow} ; 9 \stackrel{+5}{\rightarrow} ; 14 \stackrel{+6}{\rightarrow} ; 20 \stackrel{+7}{\rightarrow} ; 27 \stackrel{+8}{\rightarrow}$; $35 \stackrel{+9}{\rightarrow} ; 44 \stackrel{+10}{\longrightarrow} ; 54 \stackrel{+11}{\longrightarrow} ; 65 \stackrel{+12}{\longrightarrow} ; 77 \stackrel{+13}{\longrightarrow} ; 90 \stackrel{+14}{\longrightarrow} ; 104 \stackrel{+15}{\longrightarrow} ; 119 \stackrel{+16}{\longrightarrow} ; 135 \stackrel{+17}{\longrightarrow} ; 152 \stackrel{+18}{\longrightarrow} ; 170 \stackrel{+19}{\longrightarrow}$; $189 \stackrel{+20}{\longrightarrow} 209,-$ можно построить график квадратов (их корней) простых чисел до бесконечности. Рассмотрим образование простых чисел в функции $\operatorname{Pr}=\sqrt{9+8 n}(\mathrm{n}-$ порядок числа) 


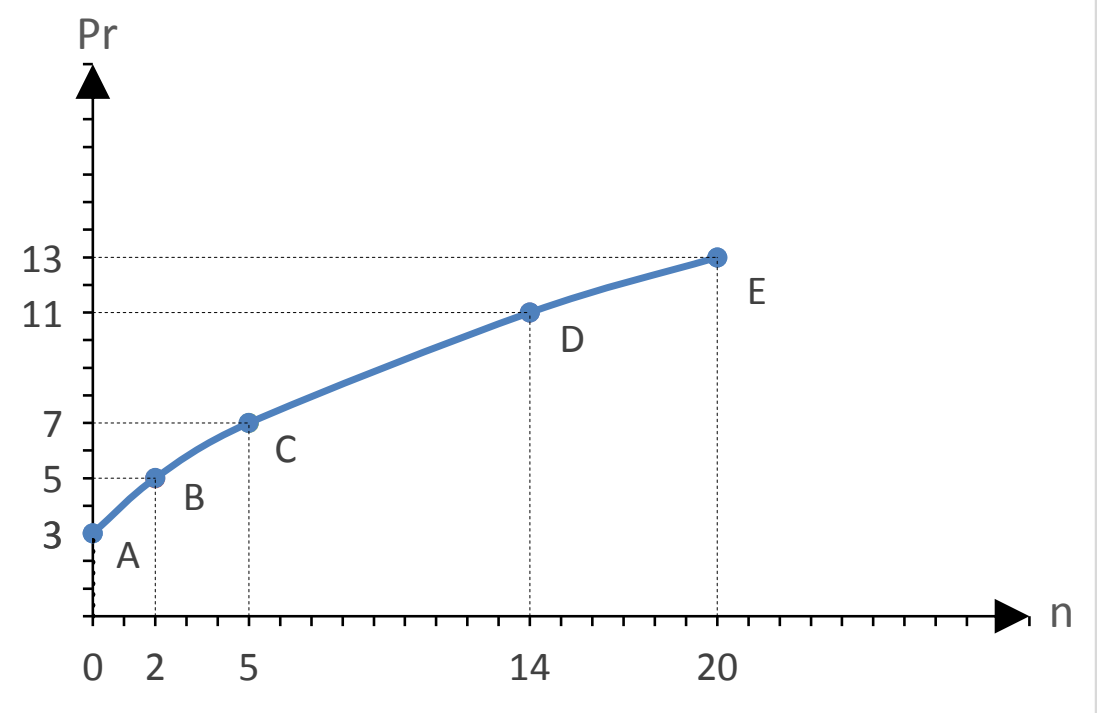

Рис.1. Зависимость значений простых чисел от их n - порядков

Образуется параболическая кривая зависимости значений простых чисел от их $\mathrm{n}-$ порядков функции $\operatorname{Pr}=\sqrt{9+8 n} \mathrm{n}=0 \rightarrow 3 ; \mathrm{A}(0 ; 3) ; \mathrm{n}=2 \rightarrow 5 ; \mathrm{B}(2 ; 5) . \mathrm{n}=5 \rightarrow 7 ; \mathrm{C}(5 ; 7)$; $\mathrm{n}=14 \rightarrow 11 ; \mathrm{D}=20 \rightarrow 13 ; \mathrm{E}(20 ; 13)$.

Если считать простые числа корнями квадратными из их квадратов, образуются точки графика $\mathrm{Y}=\mathrm{Pr}^{2}$. Точки графика : A(3;9); В(5;25); C(7;49); D(11;121); E(13;169). Образуется мало искривленная линия, под наклоном к оси $\mathrm{X}(\mathrm{Pr})$, близким к вертикальному, как предполагал Риман...

Итак, $\left\{\operatorname{Pr}^{a} \sqrt{S^{2}+\Delta} \operatorname{Pr}^{2}(=X-\right.$ нечетное число с остатком, при целых $\mathbf{n}$ - порядках $\operatorname{Pr}^{2}($ в $Y=9+8 x n(a-$ четное значение; стремится от $\infty$ ко второй степени для определения простого числа. $\{\boldsymbol{a}(\infty \rightarrow 2)$.

Построим график функции $\mathrm{Y}=\operatorname{Pr}^{2}(\mathrm{X})$. C увеличением значений «X» наклон к оси абсцисс уменьшается, кривая приобретает вид вертикальной прямой. Именно вертикальная прямая, как предполагал Риман, показывает образование простых чисел из их квадратов. 


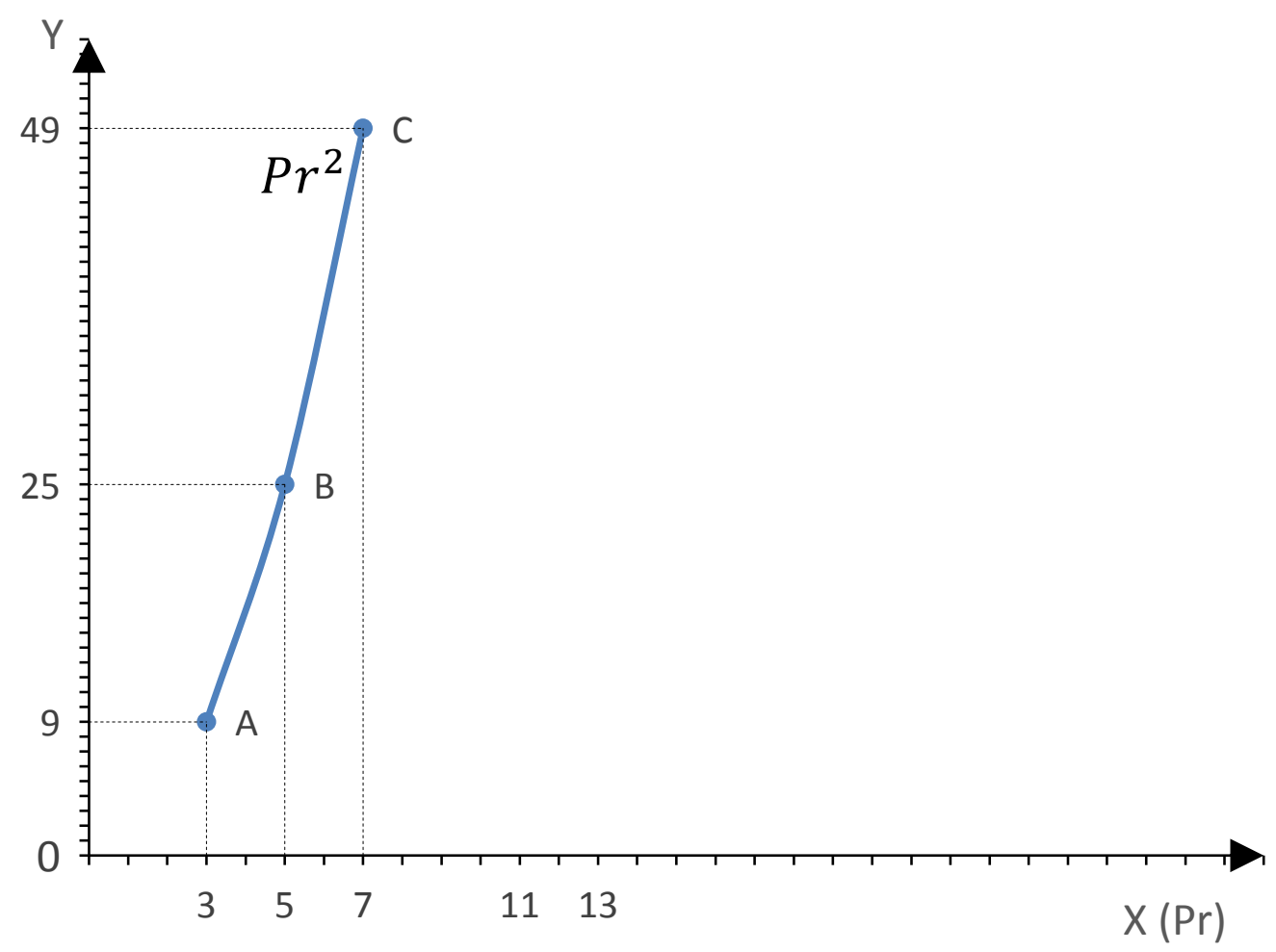

Рис.2. График функции $\mathrm{Y}=\operatorname{Pr}^{2}(\mathrm{X})$

В Y $=\sqrt{9+8 \mathrm{xn}}$ образуются и простые, и сложные нечетные числа...

$\mathrm{n}=27 \rightarrow \sqrt{225}=15 ; \mathrm{n}=35 \rightarrow \sqrt{289}=17 ; \mathrm{n}=44 \rightarrow \sqrt{361}=19 ; \mathrm{n}=54 \rightarrow \sqrt{441}=21$;

$\mathrm{n}=65 \rightarrow \sqrt{529}=23 ; \mathrm{n}=77 \rightarrow \sqrt{625}=25 ; \mathrm{n}=90 \rightarrow \sqrt{729}=27 ; \mathrm{n}=104 \rightarrow \sqrt{841}=29 \ldots$ и далее, до $\infty \ldots$

Задача произвести идентификацию простых чисел... С другой стороны известно, как от $81=9^{2}$ (квадрат первого сложного нечетного числа) - определять квадраты сложных нечетных ...Формула квадратов сложных нечетных чисел: $\mathrm{Q}=\mathbf{8 1}+(32+24 \mathrm{XX})++\sum \Delta \boldsymbol{S}^{2}[\downarrow]$, где $\sum \Delta \boldsymbol{S}^{2}[\downarrow]$ - сумма приращений промежуточных квадратов нечетных чисел (квадратов простых, $\mathrm{Pr}^{2}$ ), -отображено выше.

Учитывая это, все квадраты сложных нечетных чисел для формирования группы квадратов простых нечетных чисел следует исключить.

Таким образом, чтобы получить простые числа, следует из множества чисел функции $\mathrm{Y}=\sqrt{9+8 \mathrm{xn}}$, где способ определения $\mathrm{n}$ - порядков (по таблице, способ ее составления указан выше), -нужно исключить множество квадратов сложных нечетных чисел начиная от «81». Если множество обозначается как $\{\rightarrow \infty$, то 
множество Рг определяется так: $\{\mathbf{P} \mathbf{r} \rightarrow \infty=\{\rightarrow \infty \sqrt{\mathbf{9 + 8 \times n}}-\{\rightarrow \mathbf{8 1}+(\mathbf{3 2}+\mathbf{2 4 x} \mathbf{X})+$ $\sum \Delta \boldsymbol{S}^{2}[\downarrow]$. (Подчеркнуто единое множество).

Следует исключить также значения корней квадратных (извлеченные из $\left\{\rightarrow 81+(32+24 \mathrm{xX})+\sum \Delta S^{2}[\downarrow]\right.$ и сложные нечетные, образуемые в $\mathrm{Y}=\sqrt{9+8 \mathrm{xn}}$

До «81», - $15 ; 21 ; 25 ; 27 ; 33 ; 35 ; 39 ; 45 ; 49 ; 51 ; 55 ; 57 ; 63 ; 65 ; 69 ; 75 ; 77$. Группу этих сложных обозначим как интервал [15 ${ }^{\leftarrow S \rightarrow 77]}$ (S - сложные).

Тогда верно: (множество простых чисел до бесконечности определяется:

$\left\{\mathbf{P} \mathbf{r} \rightarrow \infty=\left\{\sqrt{\mathbf{9}+\mathbf{8} \times \mathbf{n}, \rightarrow \infty}-\left\{\rightarrow \mathbf{8 1}+(\mathbf{3 2}+\mathbf{2 4 x X})+\sum \Delta S^{2}[\downarrow], \rightarrow \infty-\right.\right.\right.$

$-\left\{\sqrt{\rightarrow \mathbf{8 1}+(32+24 \mathrm{xX})+\sum \Delta S^{2}[\downarrow], \rightarrow \infty}-\left[15^{\leftarrow S \rightarrow 77]}\right.\right.$.

Образование $\mathrm{n}$ - значений рассмотрено ранее, по схеме: $2 \stackrel{+3}{\rightarrow} 5 ; 5 \stackrel{+4}{\rightarrow} ; 9 \stackrel{+5}{\rightarrow} ; 14 \stackrel{+6}{\rightarrow} ; 20 \stackrel{+7}{\rightarrow}$; $27 \stackrel{+8}{\rightarrow} ; 35 \stackrel{+9}{\rightarrow} \ldots$, по формуле $\{\mathbf{n} \rightarrow \infty=\mathbf{2}+\{\Delta \mathbf{n} «+\mathbf{1} » \rightarrow \infty$ в каждом следующем $\mathbf{n}-$ значении. $\{\Delta \mathrm{n}$ «+ $1 » \rightarrow \infty,-$ множество приращений $\mathbf{n}-$ значений (от «2», при увеличении каждого $\Delta \mathbf{n}-$ последующего на «+1» $\sum \Delta S^{2}[\downarrow]$ сумма приращений промежуточных квадратов нечетных чисел, квадратов простых чисел.(рассмотрено ранее)...

$\left\{\sqrt{\rightarrow \mathbf{8 1}+(32+24 \mathrm{XX})+\sum \Delta \boldsymbol{S}^{2}[\downarrow], \rightarrow \infty}\right.$, - множество целых чисел, определяемое для получения и исключения минимальных значений квадратов сложных чисел. По факту значения $\left\{\rightarrow 81+(32+24 \mathrm{xX})+\sum \Delta S^{2}[\downarrow], \rightarrow \infty\right.$ и $\sqrt{\rightarrow 81+(32+24 \mathrm{xX})+\sum \Delta S^{2}[\downarrow], \rightarrow \infty}$ - должны совпадать, быть одинаковыми.

Ранее был сделан вывод, что промежуточные (между квадратами сложных нечетных), приращения квадратов нечетных (предполагаемых простых), увеличиваются в каждом значении на «+8», и известны приращения квадратов сложных нечетных чисел, что определяются по формуле: $\Delta \mathrm{S}^{2}=32+24 \mathrm{xX}$ (от «81=92»)). Значит, можно узнать значения приращений ожидаемых квадратов простых, $\Delta \operatorname{Pr}^{2}$.

Рассмотрим интервалы при различных «Х-значениях»: [32; 56; ]; [56; 80; ]..в первом образуются , $\Delta \mathrm{Pr}^{2}: 32+8=40 ; 40+8=48 ;, \Delta \operatorname{Pr}^{2} .=40 \rightarrow 81+40=121=11^{2} ; 11 \in \mathrm{Pr}$, $\Delta \operatorname{Pr}^{2}=48 \rightarrow 121+48=169=13^{2} ; 13 \in \operatorname{Pr}$. Во втором интервале образуются:

$\Delta \operatorname{Pr}^{2}=56+8=64 \rightarrow 225+64=289=17^{2} ; 17 \in \operatorname{Pr}$. (Примечание: крайним значениям интервалов в зависимости $\Delta \mathbf{S}^{2}=\mathbf{3 2}+\mathbf{2 4 x} \mathrm{X}$, - соответствуют квадраты сложных нечетных чисел, как $56 \rightarrow 225=15^{2}(169+56=225) \ldots \Delta \operatorname{Pr}^{2}=64+8=72 \rightarrow 289+72=361=19^{2}$; $19 \in \operatorname{Pr} \ldots$ 
То есть зная, что при $\mathrm{X}=0, \Delta \mathrm{S}^{2}=32$ образуется «81=92»), можно рассчитать все квадраты сложных $\left(\operatorname{Pr}^{2}\right)$ до бесконечности. Логично что $\mathbf{P r}^{2}=\mathbf{S}^{\mathbf{2}}+\Delta \mathbf{P r}^{\mathbf{2}}$ в заданном интервале $\left[\Delta \mathbf{S}_{\mathbf{1}}{ }^{2} ; \Delta \mathbf{S}^{2}\right]$

Примечание! В формуле выше в значении $\sum \Delta \boldsymbol{S}^{2}[\downarrow]$ - сумма приращений квадратов простых чисел использован символ $\mathbf{S}$, как показывающий, что сумма приращений квадратов простых чисел с позади стоящим квадратом сложного числа, -образует квадрат сложного числа в крайних значениях интервалов. К примеру:

$81+40+48+56=225=15^{2} ; 40+48=96-$ есть значение $\sum \Delta \boldsymbol{S}^{2}[\downarrow]$.

Зная приращения квадратов простых чисел и квадраты простых, им соответствующие, можно построить график зависимости $\operatorname{Pr}^{2} \rightleftarrows \Delta \operatorname{Pr}^{2}$

Возьмем минимальные значения $\Delta \operatorname{Pr}^{2}: 40 ; 48 ; 64 ; 72$. Им соответствуют значения $\operatorname{Pr}^{2}: 121 ; 169 ; 289 ; 361$.

Видно, что кривая зависимости $\operatorname{Pr}^{2} \rightleftarrows \Delta \operatorname{Pr}^{2}$ постепенно, с увеличением $\Delta \operatorname{Pr}^{2}$ выпрямляется вертикально к оси абсцисс « $\Delta \operatorname{Pr}^{2} »$, что предполагал Риман.

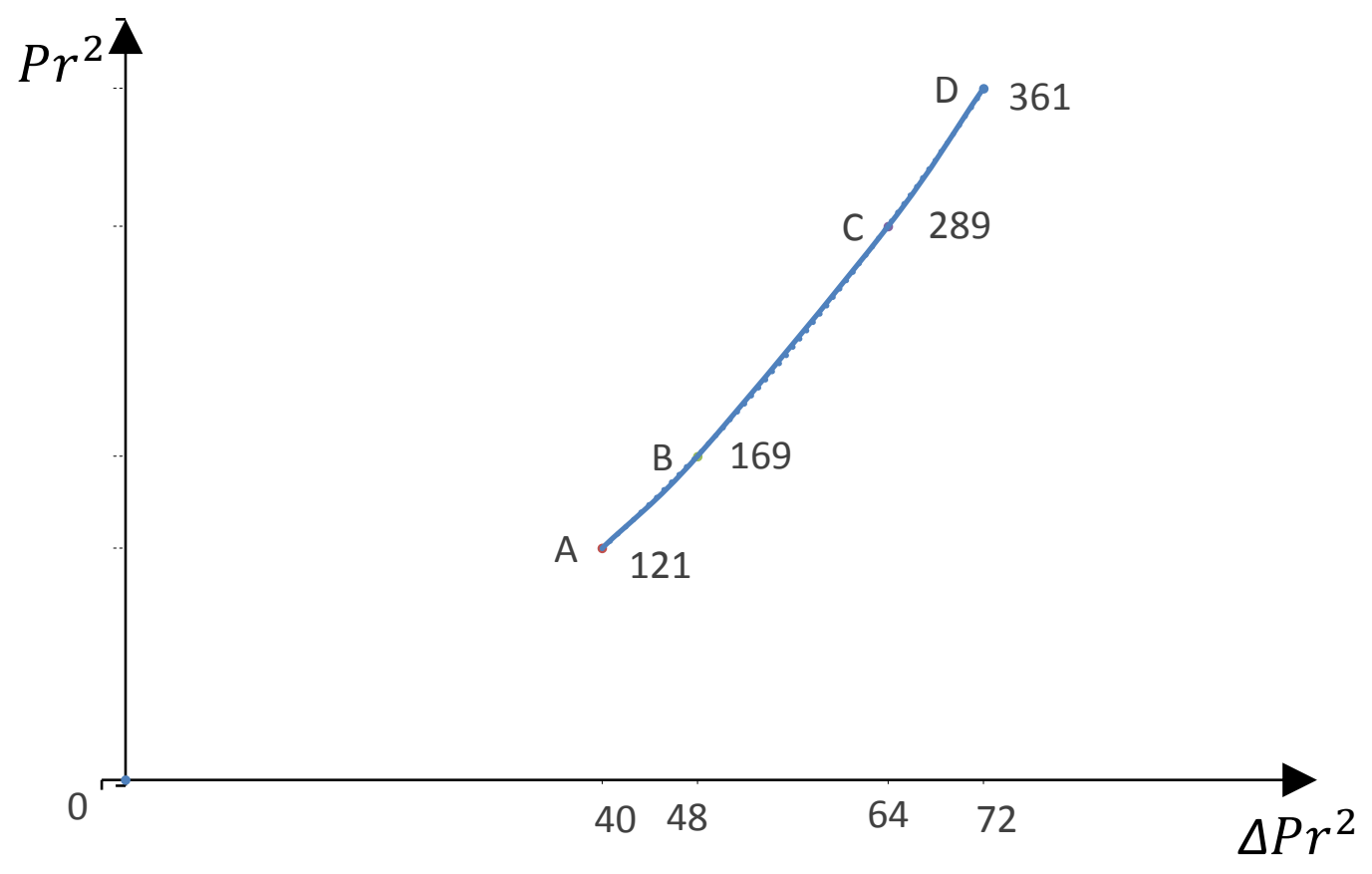

Рис.3. Кривая зависимости $\operatorname{Pr}^{2} \rightleftarrows \Delta \operatorname{Pr}^{2}$ 
Как определять значения простых чисел до бесконечности, показывают выведенные формулы выше... Можно сделать общие выводы о простых числах.

1. $\left\{\mathrm{P} \mathrm{r} \rightarrow \infty=\mathrm{Q}\right.$ (все нечетные) - $\left\{\mathrm{P} \mathrm{r}^{\mathrm{n}} \rightarrow \infty\right.$, где $\mathrm{n}$ - четная степень простых чисел, начиная от квадратной (второй) $-\{\mathrm{S}[\downarrow] \rightarrow \infty$ (множество промежуточных сложных нечетных чисел, не образованных четной степенью числа.

$2 \cdot \sqrt[n]{\{\mathrm{S}[\downarrow]} \rightarrow \infty=\mathrm{X}, \ldots-$ из множества промежуточных сложных чисел при $\mathrm{n}-$ четной степени получаются числа с остатком.

3. $\sqrt[n]{\{\mathrm{S}[\downarrow]} \rightarrow \infty=\mathrm{X}$ - целые значения корней из промежуточных сложных могут образовываться при нечетных $\mathrm{n}-$ значениях, к прмеру: $\sqrt[3]{27}=3 ; \sqrt[3]{343}=7 ; \sqrt[3]{243}=3$.

\section{4. Промежуточные сложные числа (не четные), образуются произведением}

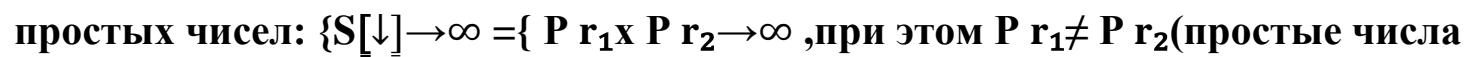
разные).

К примеру: $11 \times 13=143 ; 11 \times 17=187 ; 3 \times 73=219 ; 17 \times 67=1139$. Соответственно, общий вывод:

1.Следует дополнить, что промежуточные сложные, $\{\mathrm{S}[\downarrow] \rightarrow \infty \infty,-$ это не только значения нечетных степеней простых чисел (как 27), но и числа, образованные произведением простых...

Это можно отобразить так:

\section{1. $\left\{\mathbf{P} \mathbf{r}_{1} \times \mathbf{P} \mathbf{r}_{2} \rightarrow \infty\left(\mathbf{P} \mathbf{r}_{1} \neq \mathbf{P} \mathbf{r}_{2}\right)\right.$}

\section{2. $\left\{\mathbf{P} \mathbf{r}^{\mathrm{n}} \rightarrow \infty, \mathbf{n}-\right.$ нечетное число $\in\{\mathbf{S}[\downarrow] \rightarrow \infty$}

1-е и 2-е множества исключаются из ряда Q всех нечетных при определении простых чисел.

Решение гипотезы Римана имеет значение для современных вычислительных, компьютерных технологий...

Решение ее позволяет определить все простые числа до бесконечности...

Рассмотрим связь предположений Римана с образованием простых чисел, их квадратов... Если Z - функция Римана функция, которая любому действительному числу $\mathbf{S}$ ставит в соответствие сумму значений ряда, $\mathbf{S}=\mathbf{6}+\mathbf{i t}, \mathbf{и л и} \mathbf{S}=\mathbf{a}+\mathbf{b} \mathbf{i}$, где i мнимое (предполагаемое число); б; $\mathrm{t}$ или a; b - действительные числа, то вероятно, что есть числа, образующие (участвующие в образовании) простые, их квадраты, квадраты сложных нечетных, - по принципу этих формул(лы), применяющемся 
значении it. Такие числа называются комплексными, образующимися функцией комплексного переменного.С - комплексное число, имеет действительную и мнимую часть...Модуль (абсолютное значение) комплексного числа равен $\mathrm{Z}=\sqrt{a^{2}+b^{2}} \ldots$ Ранее указывалось, что для определения простых чисел до бесконечности надо вычислить квадраты простых чисел (до бесконечности), зная приращения квадратов простых «если простые числа считать комплексными, то их модуль равен: $\mid\left\{\boldsymbol{P r} \rightarrow \infty|=|\left\{\sqrt{\boldsymbol{S}^{2}+\Delta \boldsymbol{P r}^{2}} \mid\right.\right.$, где $\boldsymbol{S}^{2}$ - квадрат сложного нечетного числа; $\Delta P r^{2}$ - приращение квадрата простого, впереди стоящего числа. Расчет $\Delta P r^{2}$ начинаем от «32» (с увеличением каждого впереди стоящего приращения квадрата на «8»). Можно составить таблицу приращений квадратов простых чисел: 32+8=40; 40+8=48; 56; 64; 72; 80; 88; 96; 104,...и далее до бесконечности, с увеличением на «+8». Видно, что модуль комплексного числа и простые числа, исходя из возможности определять их квадраты до бесконечности, определяются принципиально одинаково. Тогда любое простое число можно считать комплексным, состоящим из двух действительных чисел, суммируемых между собой и являющихся квадратом сложного и квадратом приращения простого. Из их суммы извлекается корень второй степени... Вероятно, приращение квадрата простого можно представить как комплексное число, имеющее мнимую часть, что и дает предположение о комплексности простых чисел... Сложные нечетные числа определяются как корни квадратные из их квадратов, начиная от $81=9^{2}(9-$ первое сложное в ряду нечетных Q)... Зная, как образуются приращения квадратов сложных:

$\Delta S^{2}=32+24 \times X(32$ соответствует 81, квадрату первого сложного нечетного, 9), можно узнать значения квадратов всех сложных нечетных до бесконечности). Для этого надо суммировать приращения квадратов нечетных (в том числе и простых) до (включительно) приращения квадрата искомого сложного нечетного числа, соответствующего определенному значению $\mathbf{X}$ в формуле $\Delta \mathbf{S}^{\mathbf{2}}=\mathbf{3 2}+\mathbf{2 4} \mathbf{x} X$. При $\mathrm{X}=0 \rightarrow 81$ (первый квадрат минимального сложного,9)... Возьмем $\mathrm{X}=5$, образуется: $32+24 \times 5=152 \ldots$ Промежуточные приращения квадратов: $32+8=40 ; 48 ; 56 ; 64 ; 72 ; 80$; $88 ; 96 ; 104 ; 112 ; 120 ; 128 ; 136 ; 144 \ldots$ то есть: $S^{2}=81+\sum$ выше перечисленных чисел $+152=1521 ; \sqrt{1521}=39 ;(39: 3=13)$. Зная приращения квадратов простых и сложных нечетных чисел, можно составить таблицу приращений квадратов нечетных (сложных и простых до бесконечности, начиная от 32 $\rightarrow$ 81)... Подчеркнуты

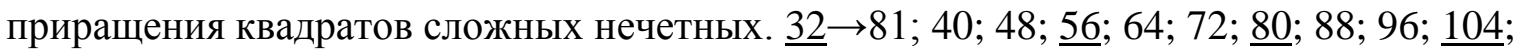
$112 ; 120 ; \underline{128} ; 136 ; 144 ; \underline{152} ; 160 ; 168 ; \underline{176} ; 184 ; 192 ; \underline{200} ; 208 ; 216 ; \underline{224} ; 232 ; 240 ; \underline{248}$; $256 ; 264 ; 272 ; 280 \ldots$ и далее до бесконечности. Видно, что любому квадрату сложного и простого числа соответствует сумма определенных значений приращений квадратов нечетных (назовем ряд Z), начиная (условно) с $32 \rightarrow 81=9^{2}$. Дзета - функция Римана об этом и говорит. Как найти нули дзета - функции? Дзета функция, - функция комплексного переменного... Говоря о ней, следует вспомнить о 
производной... Производная, - основное понятие дифференциального исчисления , характеризует скорость изменения функции... Определяется как предел отношения прироста функции к приросту ее аргумента при стремлении прироста аргумента к «О», если такой предел существует...их образование бесконечно... Производная равна: $\oint^{\prime}(\mathrm{X})=\frac{\Delta \oint}{\Delta \mathrm{X}}$,

Дзета - функция Римана является аналитической и функция зависимости приращений квадратов (простых и сложных), должна быть у них тождественна, то есть выполняется условие Коши - Римана: $\frac{\Delta \mathrm{Y}_{1}}{\Delta \mathrm{X}_{1} r}=\frac{\Delta \mathrm{Y}_{2}}{\Delta \mathrm{X}_{2} r} ;: \frac{\Delta \mathrm{Y}_{1}}{\Delta \mathrm{X}_{2} r}=-\frac{\Delta \mathrm{Y}_{2}}{\Delta \mathrm{X}_{1} r}$, где $\Delta \mathrm{Y}_{1}$ приращения (разница между квадратами сложных нечетных $\Delta \mathrm{X}_{1} r$ - разница между приращениями квадратов сложных нечетных. $\Delta \mathrm{Y}_{2}$ - разница между квадратами простых. $\Delta \mathrm{X}_{2} r$ - разница между приращениями квадратов простых... Проверим это равенство...

$32 \rightarrow 81 ; 56 \rightarrow 225$ (для сложных); 40 $\rightarrow 121 ; 48 \rightarrow 169$ (для простых); 225-81=144; 56$32=24 ; \Delta \mathrm{Y}_{1}=144 ; \Delta \mathrm{X}_{1}=24 ; 144: 24=6 ; 169-121=48 ; 48-40=8 ; 48: 8=6 ;$ возьмем $21^{2}=441 ; \rightarrow \Delta \mathrm{X}_{1}=80 ; \Delta \mathrm{X}_{2}=72 \rightarrow 361=19^{2} ; 441-225=216 ; 80-56=24 ; 216: 24=9$. Разницу между квадратами сложных и их приращениями, результат деления определили. Теперь то же сделаем с квадратами простых, расположенных между 225 и 441, то есть $289=17^{2}$ и $361=19^{2} .72-64=8\left(\Delta \mathrm{X}_{2} r-\right.$ разница между приращениями квадратов простых, $\Delta \mathrm{X}_{2}=72$ и $\Delta \mathrm{X}_{2}=64$, -равна 8). $361-289=72 ; 72: 8=9$. Такой же результат деления, 9, образуется и при рассмотрении крайних значений интервала [225; 289 ;

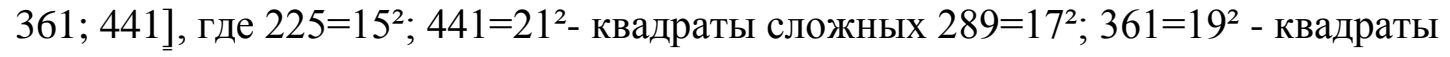
простых чисел.

Вывод: в бесконечном ряду квадратов нечетных чисел (сложных и простых) наблюдается закономерность - внутри интервалов с двумя крайними значениями квадратами сложных и двумя между, квадратами простых, - соотношения разницы квадратов к разнице соответствующих им приращений равны, соотношения для сложных равны соотношениям для простых, то есть выполняется условие Коши Римана.

$\frac{\Delta \mathrm{Y}_{1}}{\Delta \mathrm{X}_{1} r}-\frac{\Delta \mathrm{Y}_{2}}{\Delta \mathrm{X}_{2} r}=\mathbf{0}$

Этим равенством объясняется расположение «нулей дзета - функции Римана». Они образуются согласно данному условию в интервалах связи роста значений квадратов простых и сложных от их приращений, их разницы. $\left[32 \rightarrow 81=9^{2}\right.$; $\left.40 \rightarrow 121=11^{2} ; 48 \rightarrow 169=13^{2} ; 56 \rightarrow 225=15^{2}\right],\left[56 \rightarrow 225=15^{2} ; 64 \rightarrow 289=17^{2} ; 72 \rightarrow 361=19^{2} ;\right.$ $\left.80 \rightarrow \mathbf{4 4 1}=\mathbf{2 1 ^ { 2 }}\right]$, аналогично, до бесконечности. Если значениями аргумента считать значения $\mathrm{X}=\frac{\Delta \mathrm{Y}_{1}}{\Delta \mathrm{X}_{1} r}-\frac{\Delta \mathrm{Y}_{2}}{\Delta \mathrm{X} 2 r}$ внутри интервалов связи, то на оси абсцисс все значения $\mathbf{X}$ будут соответствовать «0». На оси Y приращениям будут соответствовать квадраты 
нечетных чисел (начинаем от $81=9^{2}$ согласно предыдущим расчетам. Данную функцию Z следует считать комплексной, выразив совокупностью:

$$
f(Z)=\left\{\begin{array}{l}
\mathrm{X}=\frac{\Delta Y 1}{\Delta X 1 r}-\frac{\Delta Y 2}{\Delta X 2 r} ; \\
\mathrm{Y}=\text { от } 81 \rightarrow \infty ; \mathrm{S}^{2} ; \mathrm{Pr}^{2}
\end{array}\right.
$$

Значение $81=9^{2}$ можно считать константой, постоянной величиной от которой происходит рост квадратов (сложных и простых)...

Видно, что образуется вертикальная прямая, соответствующая оси Ү,как предполагал Б.Риман.

Значению $81=9^{2}$ соответствует $\Delta \mathrm{X}_{1}=32 \ldots$ Величину «32», от которой узнаем приращения, следует считать const, от которой происходит рост по принципу комплексного числа: Z=a+bi, где a - действительная часть, соответствует const; b мнимая часть, соответствует приращению квадрата нечетного числа. $32+8=40 \stackrel{\text { образует }}{\longrightarrow}$ $81+40=121=11^{2} ; 11 \in \operatorname{Pr} .32+8+8=48 \stackrel{\text { образует }}{\longrightarrow} 81+40+48=169=13^{2} ; 13 \in \operatorname{Pr} .32+8+8+8=56$

$\stackrel{\text { образует }}{\longrightarrow} 81+40+48+56=225=15^{2} ; 15 \in$ А.(сложное A - группы). Мнимая часть (предполагаемая ) - величина не постоянная, в качестве приращения зависит от величины значений квадратов нечетных чисел, то есть переменная, образуемая комплексом (суммой) приращений от 32 на $+8 \mathrm{xn}-$ значений. Значение «8xn» есть мнимая часть, от него зависит (от n), значение функции комплексной переменной (величина приращения).

Среднее значение суммы приращений в интервалах $[32 ; 56]$; [56; 80]; [80; 104]; [104; $128]$ и далее до бесконечности, (сумма крайних значений, для сложных), не равно приращениям квадратов простых во всех интервалах, приращения квадратов простых отклоняются от середины. В интервалах $\left[\Delta \mathbf{S}_{1}{ }^{2} ; \Delta \operatorname{Pr}_{1}{ }^{2} ; \Delta \operatorname{Pr}_{2}{ }^{2} ; \Delta \mathbf{S}_{2}{ }^{2}\right]$ это выражается так: $\frac{\Delta \mathrm{S}_{1}{ }^{2}+\Delta \mathrm{S}_{2}{ }^{2}}{2} \neq \Delta \operatorname{Pr}_{1}{ }^{2} ; \Delta \operatorname{Pr}_{2}{ }^{2}$ (отсутствие равенства, о чем утверждал Риман)

Примеры: 32+56=88; 88:2=44. Приращения квадратов простых внутри данного интервала 40; 48. В интервале [56;80] среднее значение $(56+80): 2=68$; приращение квадратов простых 64; 72. В [104; 128] среднее значение 116; приращения квадратов простых 112; 120. В [128;152] среднее значение 140; приращения $\operatorname{Pr}_{1}^{2} ; \operatorname{Pr}_{2}^{2}$ равны $136 ; 144 ; \mathrm{B}[152 ; 176]$ среднее значение $164 ; \Delta \operatorname{Pr}_{1}{ }^{2}=160 ; \Delta \operatorname{Pr}_{2}{ }^{2}=168$. Видно, что приращения квадратов простых чисел в интервалах связи квадратов (их 
приращений) нечетных чисел, - отличаются от среднего арифметического значения суммы крайних значений на $\mp 4$. Эту зависимость назовем равноудаленностью приращений квадратов простых чисел. $\Delta \operatorname{Pr}_{1}{ }^{2}=\frac{\Delta S_{1}{ }^{2}+\Delta S_{2}{ }^{2}}{2}-4 . \Delta \operatorname{Pr}_{2}{ }^{2}=\frac{\Delta S_{1}{ }^{2}+\Delta S_{2}{ }^{2}}{2}+4$. Равноудаленность приращений обеспечивает упорядоченное образование простых чисел...

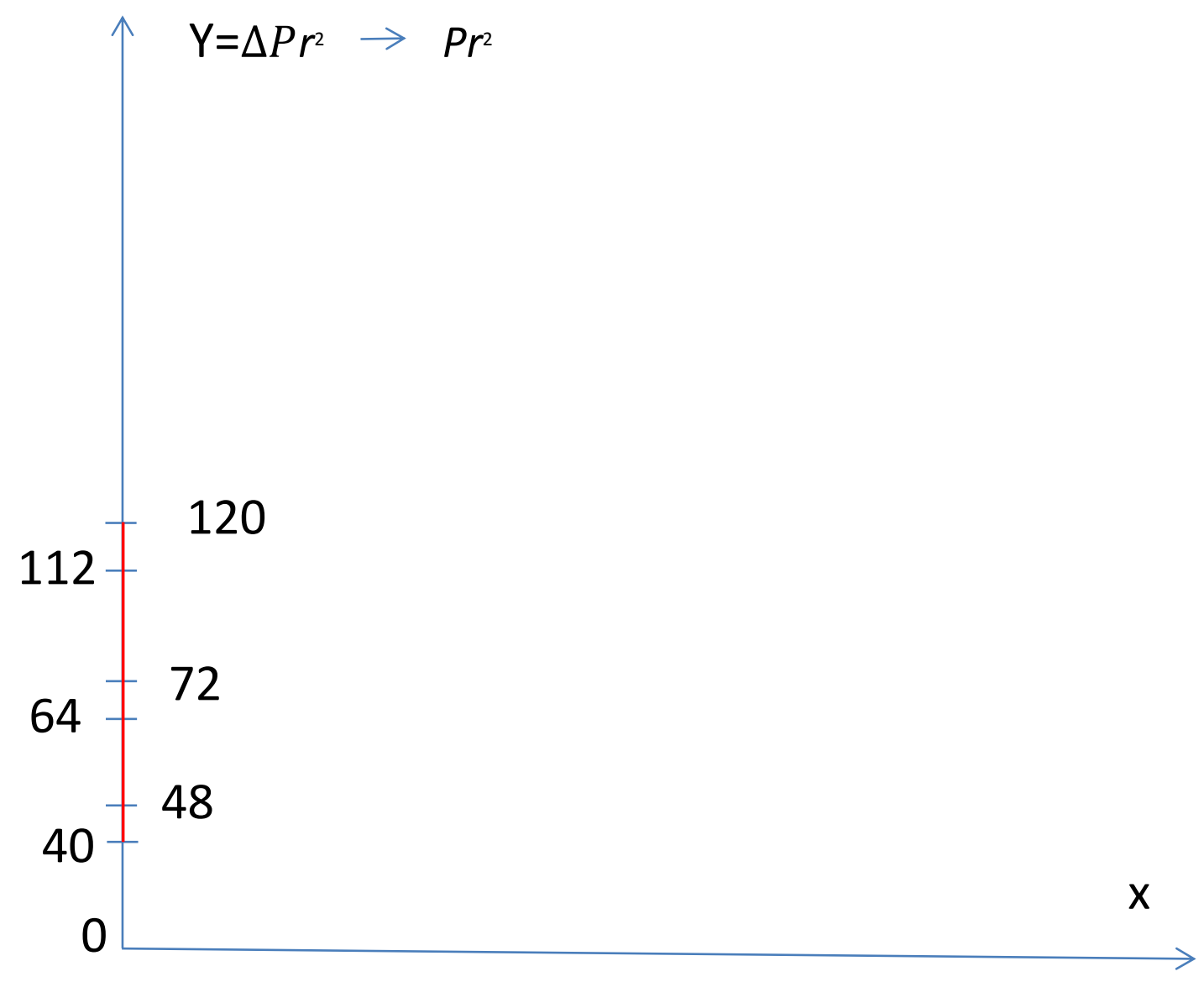

Функция Римана, Z-функция комплексного переменного, где все нули - значения «Х» (условие Коши-Римана). $\mathrm{y}_{1} ; \mathrm{y}_{2}$ - приращения квадратов простых чисел, начиная от $121=11^{2}\left(\Delta \operatorname{Pr}^{2}=40\right)$. 
Значения $\left\{\mathrm{y}_{1} ; \mathrm{y}_{2} \rightarrow \infty\right\}=\{40 ; 48 ; 64 ; 72 ; 112 ; 120 ; 136 ; 144$, и далее, до бесконечности $\}$.

Значениями $\Delta \operatorname{Pr}_{1}^{2}$ и $\Delta \operatorname{Pr}_{2}^{2}$ есть $\frac{1}{2}$ комплексного переменного, $\left(\Delta \mathrm{S}_{1}{ }^{2}+\Delta \mathrm{S}_{2}^{2}\right) \pm 4$, отклоняющегося от среднего значения на \pm 4 .

$f(Z)=\left\{\begin{array}{l}\mathrm{X}=\frac{\Delta Y 1}{\Delta X 1 r}-\frac{\Delta Y 2}{\Delta X 2 r} ;(0) . \\ \mathrm{y}_{1}=\Delta \operatorname{Pr}_{1}{ }^{2}=\frac{\Delta \mathrm{S} 12+\Delta \mathrm{S} 22}{2}-4 ;\left(\mathrm{S}_{1} \text { и } \mathrm{S}_{2} \text { в квадрате }\right) \\ \mathrm{y}_{2}=\Delta \operatorname{Pr}_{2}{ }^{2}=\frac{\Delta \mathrm{S} 12+\Delta \mathrm{S} 22}{2}+4 ;\left(\mathrm{S}_{1} \text { и } \mathrm{S}_{2} \text { в квадрате }\right)\end{array}\right.$

Примечание: выражение функции Римана в виде

$f(Z)=\left\{\begin{array}{l}\mathrm{X}=\frac{\Delta Y 1}{\Delta X 1 r}-\frac{\Delta Y 2}{\Delta X 2 r} ; \\ \mathrm{Y}=\left\{\text { от } 81 \rightarrow \infty ; \mathrm{S}^{2} ; \mathrm{Pr}^{2} .\right.\end{array}\right.$

указывает на зависимость образования квадратов нечетных чисел от их приращений.

Учитывая, что все х-значения в Z-функции Римана, согласно выполнению условия КошиРимана, всегда равны «0», а приращения квадратов простых чисел отклоняются от среднего значения приращений квадратов сложных (в установленных интервалах) на \pm 4 , получим краткую формулу Z-функции Римана:

$f(Z)=\mathrm{X}+\Delta \operatorname{Pr}_{1}^{2} ; \Delta \operatorname{Pr}_{2}^{2}$ или, $(\mathrm{X}=0)$

$f(Z)=\frac{\Delta \mathrm{S} 12+\Delta \mathrm{S} 22}{2} \pm 4-$ функция полусуммы значений аргумента с отклонением для $\Delta \operatorname{Pr}_{1}^{2}$ на «- 4»; для $\Delta \operatorname{Pr}_{2}^{2}$ на «+4» от среднего, как предполагал Риман.

\section{References}

1. Vilenkin, Schwarzburd. "Matematicheskij analiz” ["Mathematical analysis"], 1969.

Translation of the Title, Abstract and References to the Author's Language

\section{Установление закономерности образования и распределения простых чисел до бесконечности (гипотеза Римана)}




\section{Мустафаев Рустем Эйвасович}

\section{Аннотация}

В работе проанализировано образование простых чисел в связи со сложными нечетными числами, установлена формула для определения простых чисел до бесконечности.

Простые числа, расположение которых пытались объяснить с помощью асимптотического закона распределения простых чисел, важны в криптографии, навигации, имитационном моделировании, то есть их определение имеет практическое значение.

Ключевые слова: $\operatorname{Pr}$ (простое число); S - (сложное число); A - группа; S «5»; Z - группа; D - группа; образующий остаток; абсолютный вектор I $\overrightarrow{\mathrm{I}} \mathrm{I}$; основа; -; корень; корень квадратный; в функции Рr; подгруппа $\mathrm{S}$ «33»; множество X; квадрат нечетных; $\mathrm{n}$ - порядки; функция $\operatorname{Pr}$ «13»; квадраты сложных; приращение $(\Delta \mathrm{n}) ; \mathrm{Q}$ - значения; $\Delta \mathrm{n}=\mathrm{n}_{2}-\mathrm{n}_{1} ; \mathrm{n}$ - четная степень; объединяющее число; $\mathrm{S}[\downarrow]$ промежуточные сложные; идентификация; приращения квадратов; интервал; от «81»; сумма приращений; исключить; $\{\mathrm{P} \mathrm{r} \rightarrow \infty$.

\section{Лuтература}

1. Виленкин, Шварцбурд «Математический анализ», 1969. 
DOI 10.32370/2018_09_9

\title{
STOE replaces relativity and quantum mechanics
}

\author{
J.C. Hodge ${ }^{1 *}$ \\ ${ }^{1}$ Retired, 477 Mincey Rd., Franklin, NC, 28734 \\ jchodge@frontier.com
}

\begin{abstract}
BOOk Summary: Available amazon.com, morebooks.de Paperback, 416 pages ISBN-10: 6139914655 ISBN-13: 9785139914654

The need for a paradigm shift is growing. Many ad hoc models and outlandish speculations abound to model many unexplained observations. The Scalar Theory Of Everything (STOE) audacious claim of a new paradigm is supported by corresponding to relativity and quantum mechanics; by explaining many problematical observations; and by making and fulfilling several predictions. It posits 2 components of the universe emerge to form everything. It models the universe as composed of cells with Sources (spiral galaxies) and Sinks (elliptical galaxies and matter). It forms the Universal Equations, one equation to define the potential at all points and one equation that uses the potential to exert forces on matter. These equations are applied the microwave background temperature, rotation curves, asymmetric rotation curves, galaxy redshift and discrete redshift, the pioneer anomaly, light interference, etc. The wave model of light is rejected by 2 experiments predicted by the STOE. Maxwell's Equations are modified. Life and society application of the STOE principles is suggested.
\end{abstract}

keywords: diffraction, interference, light, Afshar Experiment, STOE, TOE.

*E-mail: jchodge@frontier.com 


\section{STOE REPLACES}

relativity and quantum mechanics

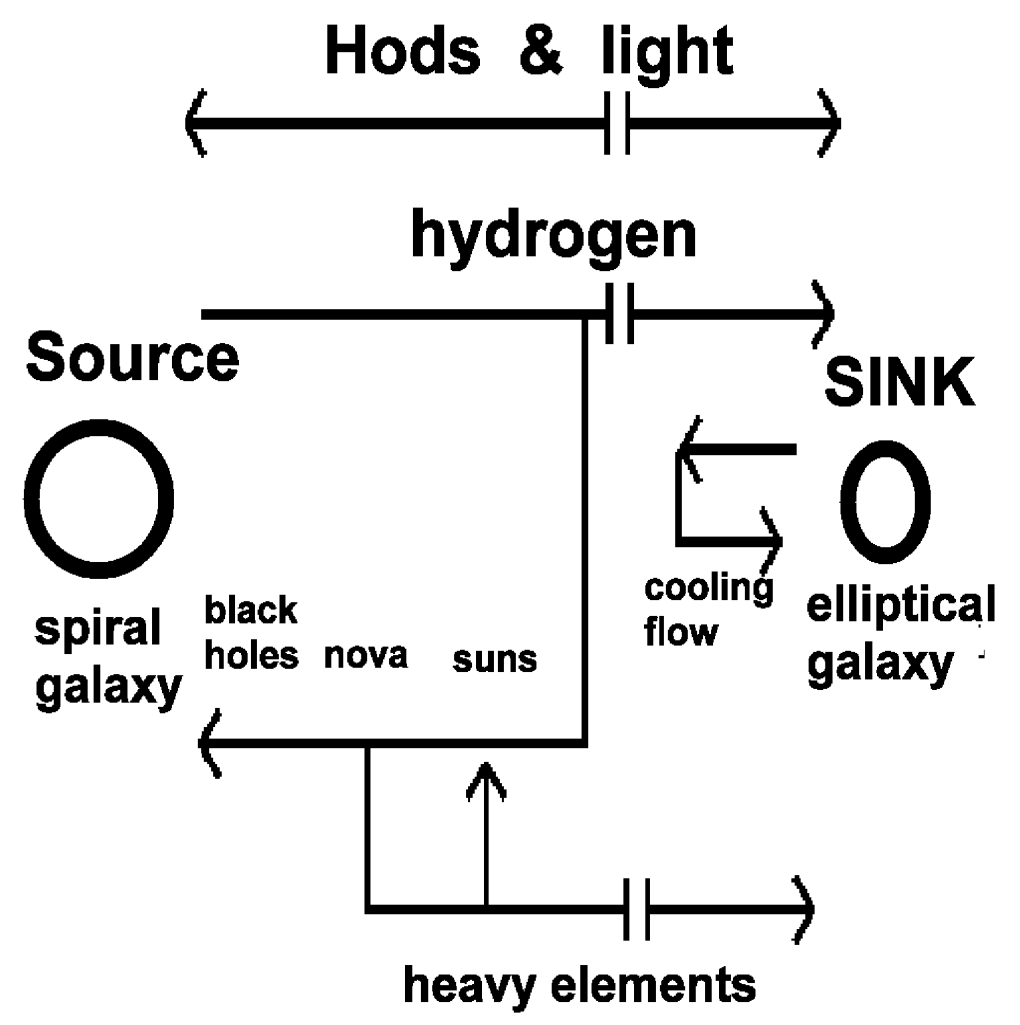

by John C. Hodge 


\section{UNIVERSAL EQUATIONS}

$$
\begin{aligned}
\rho_{\mathrm{p}}= & K_{\epsilon} \sum_{i=1}^{N_{\text {source }}} \frac{\epsilon_{i}}{r_{i}} \\
& -K_{\eta} \sum_{j=1}^{N_{\text {sink }}} \frac{\eta_{j}}{r_{j}} \\
- & K_{\text {hods }} \sum_{k=1}^{N_{\text {hods }}} \frac{K_{r}}{r_{k}} \cos \left(\frac{2 \pi r_{k}}{\lambda_{\mathrm{T}}}-\pi\right) \exp ^{-j\left(\omega t_{k}\right)} \\
> & 0
\end{aligned}
$$

$\vec{F}_{\mathrm{s}}=K_{\mathrm{G}} \sum_{l=1}^{N_{\mathrm{hods} l}} m_{\mathrm{hod}}\left(\vec{n}_{l} \bullet \vec{\nabla} \rho_{\mathrm{pl}}\right) \vec{n}_{l}$, 


\section{Contents}

Acknowledgments $\quad$ xxv

$\begin{array}{ll}\text { preface } & \text { xxvii }\end{array}$

1 Postulates 1

1.1 Introduction . . . . . . . . . . . . . . . . . . . . 1

1.2 The Principles . . . . . . . . . . . . . . . . . . . . 9

2 The Universe 17

2.1 The STOE galaxy data . . . . . . . . . . . . . 54

3 GR \& QM replacement $\quad 59$

3.1 STOE . . . . . . . . . . . . . . . . 59

3.1.1 Energy continuity equation . . . . . . . . . 66

3.1 .2 Forces . . . . . . . . . . . . . . . . 68

3.1 .3 Particles . . . . . . . . . . . . . 75

3.1.4 Chirality of matter . . . . . . . . . . . . . . . . 79

3.1.5 Source characteristics . . . . . . . . . . . 79

3.1.6 Sink characteristics . . . . . . . . . . . . . . 79

3.1.7 Equivalence Principle . . . . . . . . . . . . . . . . . 80

3.2 Sink and Source galaxies . . . . . . . . . . . . . . . 82

3.3 Hod model . . . . . . . . . . . . . . . . . . . . . . 85

3.3.1 Hod action on $\rho$-field . . . . . . . . . . . . . . 88

3.3.2 $\rho$-field action on a hod . . . . . . . . . 93

3.4 Particles . . . . . . . . . . . . . . . . . . . . 94

3.5 The analogy . . . . . . . . . . . . . . . . . . . 95

3.6 Structure . . . . . . . . . . . . . . . . . . 95

3.7 spin . . . . . . . . . . . . . . . . . . . . . . . 97

3.8 Universal Equations . . . . . . . . . . . . . . . . . . 105 
4 Modify Maxwell's Equations $\quad 107$

4.1 The model . . . . . . . . . . . . . . . . . . . 107

4.2 Experiments reject the Biot-Savart Law . . . . . . . . . . . 109

4.3 Experiment 1 . . . . . . . . . . . . . . . . . . 110

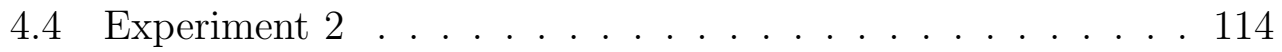

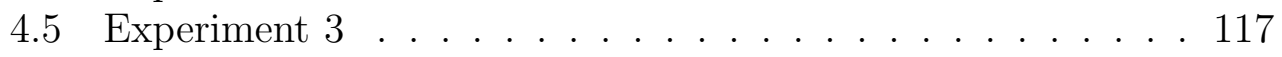

4.6 Interpretation . . . . . . . . . . . . . . . . . 117

5 Temperature of the universe $\quad 119$

5.1 Model . . . . . . . . . . . . . . . . . . . . . . 121

5.2 Conclusion . . . . . . . . . . . . . . . . . . . . . . 125

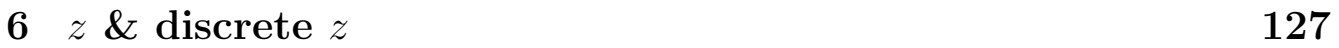

6.1 Universal Equations application . . . . . . . . . . . . . 127

6.2 Redshift model . . . . . . . . . . . . . . . . . . . . 130

6.3 Results . . . . . . . . . . . . . . . . . . . . 133

$6.4 \mathrm{X}$ factors . . . . . . . . . . . . . . . . . . . . . 140

6.5 Discrete variations in redshift . . . . . . . . . . . . 145

6.6 Discussion . . . . . . . . . . . . . . . . . . . . . . . . . . . 149

7 Pioneer anomaly $\quad 155$

7.1 Universal Equations . . . . . . . . . . . . . . . . . . . 155

7.2 labelpaintroIntroduction. . . . . . . . . . . . . . 155

7.3 Model . . . . . . . . . . . . . . . . . . . 157

7.4 Results . . . . . . . . . . . . . . . . . . 158

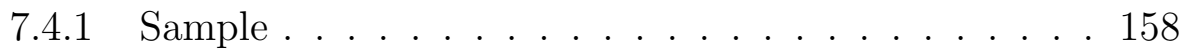

7.4.2 Annual periodicity . . . . . . . . . . . . 160

7.4.3 Difference of $a_{\mathrm{p}}$ between the spacecraft . . . . . . . . 161

7.4.4 Slow decline in $a_{\mathrm{P}} \ldots \ldots$. . . . . . . . . . . 163

7.4.5 Saturn encounter . . . . . . . . . . . . . . 163

7.4.6 Large uncertainty of P11 80/66 . . . . . . . . . 164

7.4.7 Cosmological connection . . . . . . . . . . . . 164

7.5 Discussion . . . . . . . . . . . . . . . 165

8 Rotation Velocity vs Inner Radius 169

8.1 Universal Equations . . . . . . . . . . . . . . . . . . . . . . . 169

8.2 Introduction . . . . . . . . . . . . . . . . . . . . . 169

8.3 Sample . . . . . . . . . . . . . . . . . . . . . . . . . . . . . . . . . . . . . . . . . . . . . .

8.4 Analysis . . . . . . . . . . . . . . . . . . . . 173

8.4.1 Using DSS Data . . . . . . . . . . . . . 175 
8.4.2 Using HST Data . . . . . . . . . . . . . . . . . . . 182

8.5 Discussion . . . . . . . . . . . . . . . . . 187

9 Distance calculation $\quad 191$

9.1 Model . . . . . . . . . . . . . . . . . . . . . . . . . 192

9.2 Data and Analysis . . . . . . . . . . . . . . . . . . . . 194

9.3 Discussion . . . . . . . . . . . . . . . . . . . . . . . . . . 202

10 RCs \& asymmetric RCs 205

10.1 Universal Equations . . . . . . . . . . . . . . . . 205

10.2 Introduction . . . . . . . . . . . . . . . . . . . 205

10.3 Spiral galaxy model . . . . . . . . . . . . . . . . . 210

10.4 Results . . . . . . . . . . . . . . . . . . . . . 211

10.4.1 Sample. . . . . . . . . . . . . . . 211

10.4.2 First approximation . . . . . . . . . . . . . 212

10.4.3 Second approximation . . . . . . . . . . . . . . . . 225

10.5 Discussion . . . . . . . . . . . . . . . . . . . . 227

11 CMO \& $\sigma$ correlation $\quad 231$

11.1 Universal Equations . . . . . . . . . . . . . . . . . . . 231

11.2 Introduction . . . . . . . . . . . . . . . . . . 231

11.3 Sample . . . . . . . . . . . . . . . . . . . . 235

11.4 Results . . . . . . . . . . . . . . . . . . . . 237

11.5 Discussion . . . . . . . . . . . . . . . . . . . . 238

12 Photon diffraction and interference $\quad 241$

12.1 Universal Equations . . . . . . . . . . . . . . . . . . . 241

12.2 INTRODUCTION . . . . . . . . . . . . . . . . . . . . 241

12.3 Model . . . . . . . . . . . . . . . . . . . . 247

12.3.1 Photon action on $\rho$-field . . . . . . . . . . . . . . 249

$12.3 .2 \rho$-field action on a photon . . . . . . . . 2 250

12.4 Simulation . . . . . . . . . . . . . . . . 250

12.5 Photons traveling a long distance . . . . . . . . . . 251

12.6 Young's experiment . . . . . . . . . . . . . . . . 258

12.7 Laser . . . . . . . . . . . . . . . . . . . . . . . 260

12.8 Afshar experiment . . . . . . . . . . . . . . 265

12.9 Discussion . . . . . . . . . . . . . . . . . 266

12.10Single Photon diffraction and interference . . . . . . . . . . 269

12.10.1 INTRODUCTION . . . . . . . . . . . . . 269

12.10.2 Model . . . . . . . . . . . . . . . . . 270 
12.10.3 Simulation . . . . . . . . . . . . . . 271

12.10.4Screen . . . . . . . . . . . . . . 271

12.10.5 Mask . . . . . . . . . . . . . . . 271

12.10.6 Correspondence with the Fraunhofer model . . . . . . 275

12.10.7 Discussion . . . . . . . . . . . . . 275

12.11Diffraction experiment rejects wave models of light . . . . 276

12.11.1 INTRODUCTION . . . . . . . . . . . 276

12.11.2 The experiment . . . . . . . . . . . 276

12.11.3 Edge experiments . . . . . . . . . . . . . . 279

12.11.4 Discussion . . . . . . . . . . . . . . . 281

12.11.5 Conclusion . . . . . . . . . . . . . . . . 284

12.12opaque strips \& about the Afshar Experiment . . . . . . . . 284

12.12.1 INTRODUCTION . . . . . . . . . . . . . 284

12.12.2 Experiment . . . . . . . . . . . . . . 285

12.12.3 Discussion and Conclusion . . . . . . . . . . . 293

12.13with a transparent mask rejects wave models of light . . . . 293

12.13.1 INTRODUCTION . . . . . . . . . . . . . . . 293

12.13.2 The Description of the experiment . . . . . . . 293

12.13.3 The Toy Simulation of the experiment . . . . . . . . 294

12.13.4 Discussion and Conclusion . . . . . . . . . . . 294

13 Replacement of Special Relativity 299

13.1 Universal Equations . . . . . . . . . . . . . . . . . . . 299

13.2 INTRODUCTION . . . . . . . . . . . . . . . . . . . . . 299

13.3 Null experiments . . . . . . . . . . . . . . . . . . 300

13.4 Length contraction . . . . . . . . . . . . . . 300

13.5 Doppler shift . . . . . . . . . . . . . . . . 301

13.6 Clocks . . . . . . . . . . . . . . . . . . . 302

13.7 Time dilation . . . . . . . . . . . . . . . . . . . . 302

13.8 Discussion and Conclusion . . . . . . . . . . . . . . 304

$\begin{array}{ll}14 \text { Life and survival } & 305\end{array}$

14.1 The purpose of life is life . . . . . . . . . . . . . . . 307

14.2 The nature of nature . . . . . . . . . . . . . . . . . . . . . 316

14.3 Biological to Social Mechanisms . . . . . . . . . . . . . . . 327

14.4 The Vital Way to life . . . . . . . . . . . . . . . . . . 333

15 STOE comparison to current models $\quad 347$

16 Speculations $\quad 351$ 


\section{Manuscript Guidelines}

1. All submitted papers must contain the Title, Name of author(s), Affiliation (if any), Abstract and List of References (Literature) written in English. The Abstract must count not less than 100 and not more than 300 words and must be the good representation of your article. Optionally paper may also contain this information duplicated in another language.

2. Font faces. Arial, Times, Times New Roman, Courier New and Helvetica.

3. Language. You may use any language for your paper text, however English is MUCH preferable.

4. Title. Font size - 16, bold. Position - central alignment.

5. The author's name. Font size - 14, bold. Position - central alignment.

6. The affiliation (your University etc). Font size - 14, regular (not bold). Position - left alignment.

7. The word "Abstract". Font size - 12, bold-italics. Position - central alignment.

8. The text of the abstract. Font size - 10, regular (not bold).

9. The word "Keywords" (if any). Font size - 10, bold. Position - left alignment.

10. The text of keywords (if any). Font size - 10, regular (not bold). Position - left alignment.

11. Text of article. Font size - 14. Position - left alignment or fully justified. Line spacing - 1.5 lines.

12. The word "References" (if any). Font size - 12, bold-italics. Position - central alignment.

13. The text of References (if any). Font size - 12, regular (not bold).

In all other cases please use your own good judgment or contact our Editorial Board.

\section{Where to find us}

The "IntellectualArchive" is distributed to major libraries across Canada and the US, including

Library of Congress, USA (http://lccn.loc.gov/cn2013300046 ) ,

Library and Archives Canada

(http://collectionscanada.gc.ca/ourl/res.php?url_ver=Z39.88-2004\&url_tim=2012-09-

05T01\%3A46\%3A54Z\&url_ctx_fmt=info\%3Aofi\%2Ffmt\%3Akev\%3Amtx\%3Actx\&rft_dat=40904933\&r

fr_id=info\%3Asid\%2Fcollectionscanada.gc.ca\%3Aamicus\&lang=eng) and others.

The references to articles published in the "IntellectualArchive" are available in the

Google Scholar, (http://scholar.google.ca/scholar?q=\%22IntellectualArchive\%22 ),

Arxiv.org (http://search.arxiv.org:8081/?query=\%22Intellectual\%20Archive\%22\&in= ),

WorldCat.org (https://www.worldcat.org/search?q=n2\%3A1929-4700\&qt=advanced \&dblist=638 ) ,

Academia.edu

(http://www.academia.edu/15503799/Light_diffraction_experiments_that_confirm_the_STOE_model_and

_reject_all_other_models )

The National Research Council (Italy) (http://data.cnr.it/data/cnr/individuo/rivista/ID658222 )

Наукова бібліотека of the University named after Dragomanov, Ukraine

(http://enpuir.npu.edu.ua/handle/123456789/7974?mode=full )

Google.com (https://www.google.ca/\#q=site:IntellectualArchive.com ) thousands of links etc. 